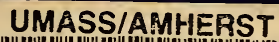

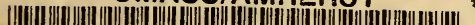

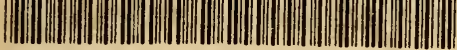

312066005827? 14 


\section{LIBRARY}

OF THE

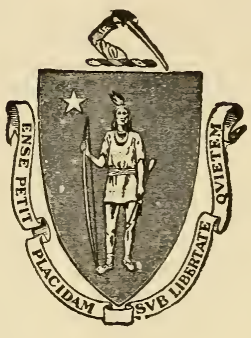

\section{MASSACHUSETTS AGRICULTURAL COLLEGE}

No...15?3 DATE M-1885

SOUR

SE

263 W69
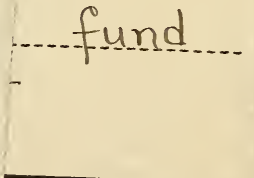


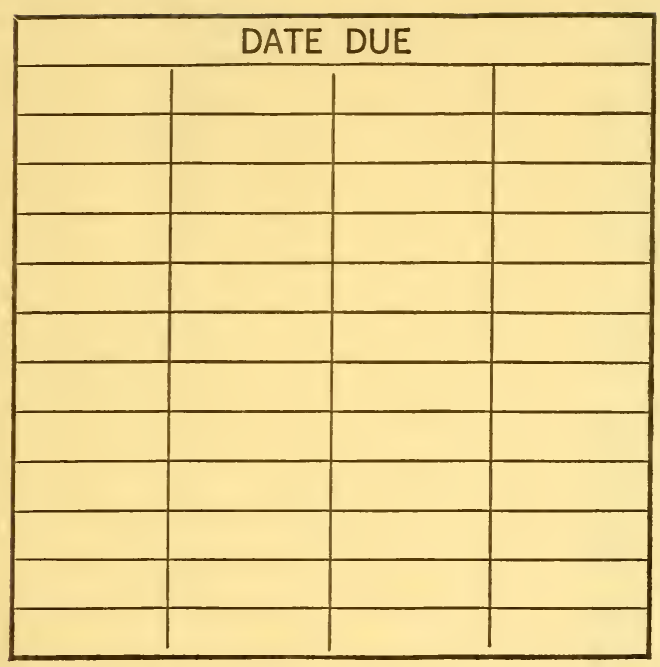

A, E, i

riा तो A

EQ

$A R F$

CAISD.

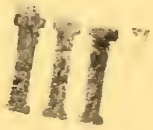




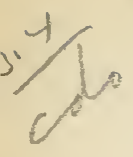

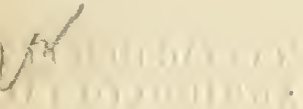



inat

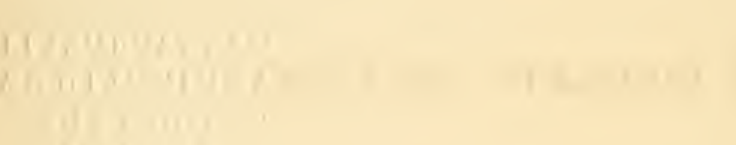
Mhas. 


\section{WILLARD'S}

\section{ofititutint
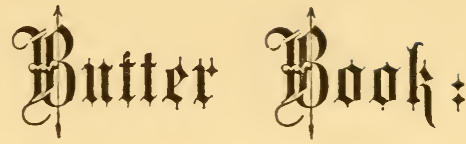

\section{A COMPLETE TREATISE}

ON BUTTER-MAKING AT FACTORIES AND FARM DAIRIES, INCLCDING THE SELECTION, PEEDING AND MANAGEMENT OF STOCK FOR BUTTER DAIRYING-WITH PLANS FOR DAIRY ROOIS AND

CREAMERIES, DAIRY FIXTURES, UTENSILS, ETC.

\section{B Y}

\section{A. WILLARD, M.A.,}

AUTHOR OF "PRACTICAL DATRY HUSBANDRY" " ESSAYS ON AGRICULTURE," "MILK CONDENSING FACTORIES," EDITOR OF DAIRY DEPARTMFNT OF MOORE'S RERAL NTW-YORKERPRESIDENT N. Y. STATE DAIRYMEN'S ASSO., ETC.

\section{SECOND EDITION.}

NEW YORK :

RURAI, PUBLISHING COMPANY, RURAL NEW-YORKER OFFICE. 


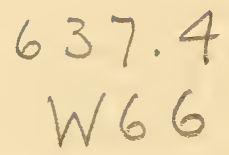

Entered according to Act of Congress, in the year 1875, by THE RURAL PUBLISHING CO.,

In the office of the Librarian of Congress, at Washington. 


\section{PREFA CE.}

BUTTER-dairying is a specialty of such large and growing importance that a treatise wholly devoted to that interest, it would seem, is very widely demanded. I have endeavored to meet this general want by supplying full information concerning the latest improvements in creamery practice, and by furnishing a work that is a safe, practical and comprehensive butter manual. The work has been freshly written, and gives the result not only of my own experience, and extensive personal observation, but the most approved practice of the best butter-makers at home and ahroad.

In the matter illustrating the secretion of milk and mammary gland, I am indebted mainly to the writings of Prof. Srmonds, the distinguished Veterinary Surgeon to the Royal Agricultural Society, of England.

Among the new topics of interest, and which heretofore have not been presented to the dairy public are: Prof. WILKInson's plan for controlling temperature in dairy rooms ; the Swedish System of setting milk for cream in ice water; the new practice adopted at the Ridge Mills Creamery, and the recent method for improving skimmed milk in skimmed-cheese manufacture. These are very fully discussed, and will be found suggestive to practical and progressive butter-makers.

That the work may prove useful to the large class for which it is intended, is the sincere wish of the author.

Little Falls, N. Y., June, 1875.

X. A. W. 


\section{INDEX OF ILLUSTRATIONS.}

Aerator...................................................... 66

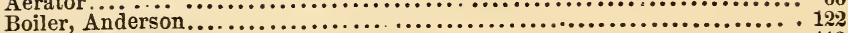

"، and Engine.............................................. 118

" Iron Slave............................................... 119

" Roe's.................................................. 120

Butter Box, with ice-chamber ................................. 111

" Factory, ground plan of .................................. 123

“ Factory, original, ground plan of.................................. 93

، Pail, Wescott s Return................................... 10 s

" Pail, enameled ............................................... 145

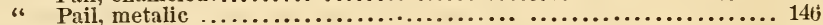

، Package, White's............................................. 110

، Worker, Champion................................................... 105

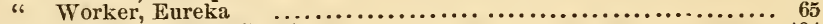

" Worker, Orange County..................................... 104

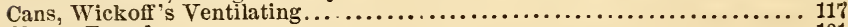

Churn, Barrel..................................................... 101

"6 Blanchard................................................ 100

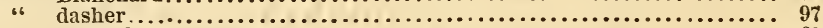

" Tornado.................................................... 63

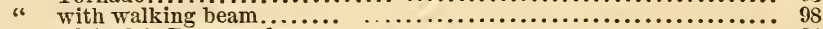

6 Whipple's Rectangular..................................... 64

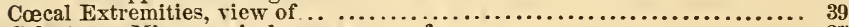

Colostrum, Microscopical appearance of.............................. 37

Cover, for cooling vat................................................ 164

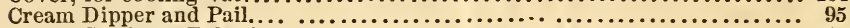

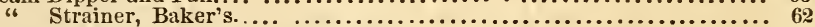

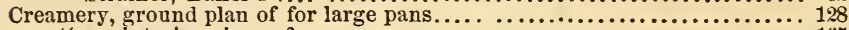

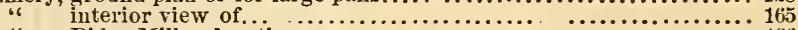

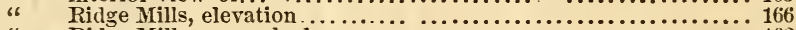

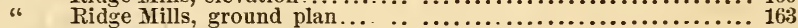

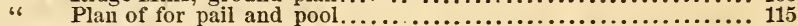

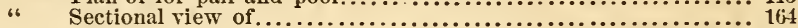

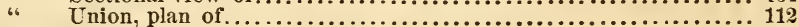

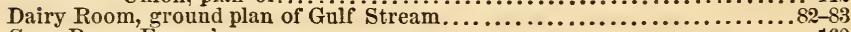

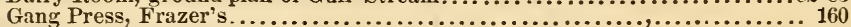

Milk Cellar, Crozier's................................................ 74

"6 Globules, Microscopical appearance of............................... 36

" Pan, Iron Clad.....................................................

" Pan, Cowles..................................................... 127

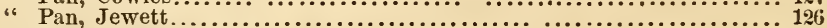

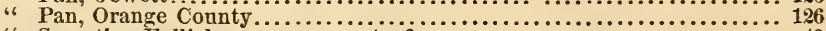

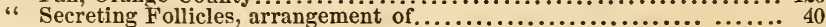

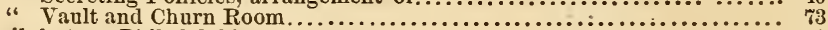

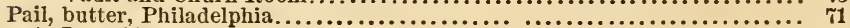

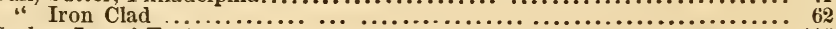

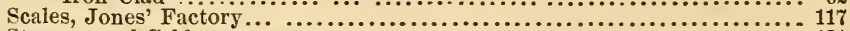

Steamer and Caldron............................................... 121

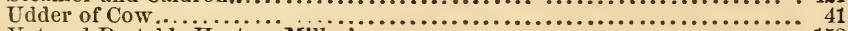

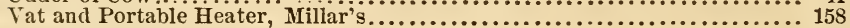

" and Heater, Roe's............................................. 159

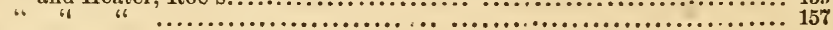




\section{IHPORTANCE OF BUTTER DAIRYING.}

\section{THE BUTTER CROP.}

The annual butter crop of the United States has been variously estimated at from $700,000,000$ to $1,000,000,000$ of pounds. But enormous as these figures are, the leading butter merchants of New York believe the product to be larger. During the summer of 1864 the New York Butter and Cheese Exchange appointed a committee of eminent merchants to consider the subject of classifying and grading butter, in order to facilitate trade in this important staple.

The committee, in its report, states that the census returns of dairy products are incomplete and defective ; and it is affirmed, further, that the latest, the most analytical and reasonable estimate in regard to the present butter crop of the country is the following, which was prepared by an experienced and careful statistician, who estimates the annual product to be over $1,400,000,000$ pounds. If the average price be put at $30 \mathrm{c}$. per pound-a sum which would not be considered excessive for a fine quality of butter-we find the total value of the product to be $\$ 420,000,000$.

The quantity, in my opinion, is estimated at too high a figure; yet it is believed by many persons who are well acquainted with the trade, to be much nearer the truth than the census returns.

Mr. Fairfield, President of the Butter and Cheese Exchange, in a recent statement in regard to the statistics of American dairy products, puts the consumption of butter in the United States at 1,040,000,000 pounds per annum for table use alone, and says it is estimated that one-third more may be added for culinary purposes, making a total consumption of about $1,387,000,000$ pounds. The exports from the United States and Canada are about $15,000,000$ pounds, making an annual product of $1,402,-$ 000,000 pounds. Mr. FAIRFIELD also calls attention to 
the incompleteness and uselessness of the statistics of the Census Bureau, and suggests the establishment of a Bureau of Statistics at Washington, which shall furnish complete and trustworthy figures bearing upon all agricultural produets.

\section{THE RATE OF BUTTER CONSUMPTION.}

Nor does the quantity seem so extravagant when the estimates of consumption are given in detail, especially when it is considered that Americans are excessively fond of this article of food. The report referred to estimates that out of our population, $5,000,000$ consume one pound of butter each per week; 10,000,000 consume three-fourths of a pound each per week; 10,000,000 consume one-half pound each per week and 10,000,000 consume one-quarter pound each per week.

At this rate, 35,000,000 would consume 1,040,000,000 pounds per annum for table use and one-third as much as the above for culinary purposes. This leaves a population of 9,000,000 not inclnded as consumers. In addition, the exports from the United States and Canada are estimated at upwards of $15,000,000$ pounds, making the product aggregate as before stated $-1,400,000,000$ of pounds.

NUMBER OF COWS REQUIRED FOR THE BUTTER CROP.

Now, from statistics in regard to the distribution of the entire milk product of the country, it is estimated that at least 54 per cent. is employed for butter-making. Then, if 200 pounds of butter per annum to the cow be taken as an average, it would require $7,200,000$ cows to make the annual yield of $1,440,000,000$ pounds. This would make the number of milch cows in the United States at the present time to be a little over $13,000,000-a$ number which many believe is not far out of the way, as wonld be shown if the census were accurately taken to-day, enumerating all the cows-the family cow as well as those employed in the various branches of dairying.

\section{CONSUMPTION INCREASES AS QUALITY IMPROVES.}

It has been observed-and indeed, the fact seems to be beyond question-that as we improve the quality of our dairy products, the consumption per capita increases; 
and this has been especially so in regard to butter since the improvement in its quality on account of the introduction of the creamery system.

A well-known dealer of my acquaintance illustrates this by a conversation which took place during the past summer between him and one of his customers. The dealer had been supplying his customer with fresh creamery butter of the finest quality. Ore day the customer came into the store and the dealer inquired as to the quality of the last tub of butter furnished. The customer said there could be no fault found with the quality, but that he should be obliged to discontinue its use, as a dollar per pound for butter was more than he could well afford. This statement very much disconcerted the dealer, as he thought that some of his clerks, perhaps, had carelessly sent up an erroneous and outrageous bill, and he hastened to assure his customer that there must be some mistake, as there was no intention of charging more than the market price, which was then some 33c. per pound. "And," said he, "I asked my book-keeper, with considerable trepidation, to turn back to the account and correct the error that had been made." But on referring to the books, it appeared that only the regular market price had been charged and credited; and on announcing this to the customer, he acknowledged that indeed he had paid no more than the sum stated, but that the consumption of the creamery butter had been three times greater per day, by his family, than when supplied with the ordinary butter obtained of the grocer-and thus the cost might be said to average a dollar per pound. "In other words," said he, "your creamery butter is so delicious, that my family never seem to get enough to satisfy them, and a tub of butter vanishes like the dew."

\section{PRICE OF BUTTER ADVANCING ABROAD.}

Another feature of importance in regard to butter may be mentioned in this connection: the price-though at times liable to fluctuate like that for other commoditiesappears on the whole to be gradually rising. The English markets have shown this for several years past. During the last two years, and especially during 1874, the trade in London has complained of the scarcity of a good article. Butter imported into England from the 
continent of Europe has been quoted as high as 168 shillings sterling per cwt. That is to say about 36 cents, gold, per pound. High prices in England have a tendency to maintain good prices on this side.

But in addition to this outlet the time is close at hand when the entire demand for dairy products in the West Indies and South America will be supplied firom the United States, and will become an important trade. Increased transportation facilities, the use of metalic packages, and improved methods of putting down butter, so that it will remain unimpaired during the sea voyage, together with the best methods of manufacture, must add greatly to the prosperity and permanency of this branch of dairying. The estimates presented will be sufficient for dairymen to fully appreciate the situation.

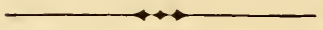 \\ THE BUTTER COT--ITS MANAGEYENT, ETC.,}

The limit assigned for this book will not permit me to enter upon an elaborate treatise in regard to the different breeds of milcn stock. Nor can any one breed be recommended for all situations, or to best suit the wants of all persons engaged in butter dairying. Farms differ widely in their character. Some lands have a level surface, others are rolling or gently undulating, while others yet are hilly and broken. Soils, too, vary from the richest to the poorest. Again, one farmer desires to make butter and cheese; another wants to get the best returns from his animals in butter, cheese and beef, or in butter and beef, while a third is looking simply for the best butter yield alone. It is evident no one breed will fulfill all these conditions at once and at the same time. As a general principle, it may be affirmed that good butter can be produced from any breed, and not unfiequently a 
common cow, with no renowned blood in her veins to boast of, will yield as much and as good butter as the boasted cow that has a long record in the herd book.

As a rule, it may be said that the small breeds give the richest milk. The Jersey, the Deron and the Ierry are perhaps the most noted in this regard. They do not yield so large a quantity as some other breeds; nor does it always follow that a cow giving very rich milk will be the most profitable for butter-making, becuuse a cow yielding a larger quantity of average good milk may make better returns in butter. The Arrshire is conceded to give a large quantity of milk of arerage good quality, but inferior in richness to that of the Jersey or Devon, and on some farms she may be the best butter cow. The same may be said of the Short Horn and other breeds.

The Jersey cow has some characteristics not common with other breeds. She vields not only a vers rich milk, but it is of a deep, yellow color, and the buitter is of a harder and more waxy texture than that from other breeds. Among butter dairymen the pure-bred Jersey, or a dash of Jersey blood, is very much esteemed. Some have claimed that the butter from Jersey cows, on account of the peculiarities named, has a superiority which will command a better price than other butter. This, howerer, may be considered a doubtful claim. At least it is not made good in the London market, where considerable quantities of Jersey butter are sold, which always brings a lower price than sereral other kinds. But whether this be due to peculiarities in flavor and texture, or to a less skilliul method of manufacturing, is a question also of consideration. Mr. Charles L. Flint, Secretary of the Massachusetts Board of Agriculture, aftirms that Jersey butter has a peculiar flaror, which is not fancied in Boston. On the other hand, much of the highpriced butter of Philadelphia is made from Jersey cows. Hence we do not regard the claim of superiority or inferiority, on account of the breed, of much account, believing that fine butter, by proper manufacture, can be mare from different breeds.

The dairyman should have a clear understanding as to his situation, the character of his lands, and what he is seeking to realize from his stock, and then choose that 
breed which is best adapted to his purpose. But in saying this it must not be inferred that we regard a thorongh-bred herd as indispensable; on the other hand, the cheapest and perhaps the most practical course to be adopted will be to select the best common cows that are to be had, and cross them with a thorough-bred bnll of the breed best adapted to his purpose. Breeding in this way, from year to year, he will be likely to obtain a herd that will yield hin the most profit, and at the least expense.

THE MILK OF EACH ANIMAL SHOULD BE TESTED.

In choosing stock for the butter dairy, each cow should be tested separately as to the quantity and quality of milk she is capable of yielding. The milk should be accurately weighed or measured and then set aside to cream, and the percentage of cream determined. But this will not be sufficient, for some cows will give a large pereentage of cream, yielding a comparatively small quantity of butter. The cream, therefore, must be churned and the percentage of butter obtained. In this way the dairyman will be able to form a true estimate of the amount of butter in each cow's milk, and from such estimate he will learn what animals in his herd are best adapted to butter-dairying, and those that should be discarded as not fitted for his business.

Large losses are often sustained by keeping inferior stock. Hany dairymen can give no accurate account of the value of any cow's milk in the herd. They know at the end of the year the quantity of butter that has been produced from the whole herd; but if it falls below what would be considered an average product they are unable to point to the true cause of the deficiency. Not unfrequently the cow that gives a large mess of milk is credited much higher than the one yielding a moderate quantity, and yet the latter, on account of its superior richness, may be altogether the best butter cow. Some dairymen are under the impression that exceedingly rich milk is made by excessive feeding, ignoring the fact that the real butter cows nust be sought for in particular animals or breeds noted for this peculiarity. Every cow has a structural limit in the richness of milk which she will yield, and beyond this standard of richness no amount of 
feeding will increase. Butter dairymen, therefore, should be careful to test the capacity of each cow in this regard, and they should enter her record on a book kept for the purpose, so that they may know what animals are yielding a profit and those that are not paying the expenses of their keep.

THE PER CENT. CREAM GAUGE.

A vessel for obtaining the percentage of cream can be readily made on the plan suggested by Mr. Douglass, of Vermont. He takes one of the common cans or pails used in the pool system-a can, say 20 inches deep by 8 inches in diameter. Then by cutting out a slot in the can and inserting a strip of glass in grooves, the edges cemented with white lead, so as to be water-tight, a convenient per cent. cream gauge may be had. Now graduate the vessel, placing the marks on the tin alongside of the glass strip, and the work is done. By setting the milk in this vessel and allowing the cream to rise, its percentage may be seen through the glass, and read on the scale.

\section{THE ATERAGE BUTtER PRODECT OF COWS.}

The average annual product of good cows, say in moderate sized herds of from 15 to 25 animals, in grood dairy districts, is about 200 pounds. Extra herds not unfrequently make an average of 250 to 300 pounds to each cow, while individual cows, as it is well known, are often reported as yielding a much larger product. The quantity of milk required to make a pound of butter ranges from eight to twenty quarts. The dairyman, therefore, as we have remarked, should satisfy himself by repeated experiments on individual cows, whether those that yield most milk are, after all, the most profitable for his particular purpose. A writer in "Morton's Cyclopedia "obtained the following results in experiments on a small dairy of 5 cows; the object being to determine the exact quantities of butter and cheese in the milk of each: A weighed quantity of milk was taken from the noon's milking of each, and allowed to stand in separate glass vessels for forty-five hours. A portion of the "strippings" of all the cows, mixed, was also set apart, to determine the amount of butter and cheese in the last 
drawn milk. When the cream had completely separated from the milk, a fine-pointed glass syphon-sufficiently wide in the bore to allow the milk to run through it, but not the cream-was introduced into the vessel, and nearly touching the bottom. The air was then exhausted from the syphon, and the milk withdrawn into another vessel. The creain was then weighed and agitated in a glass tube, until the butter came, which was then well washed with pure water and repeated decantings until the water ran off colorless. The weight of the butter was then carefully ascertained, and the difference between it and the cream gave the weight of the buttermilk. The butter was then put in a minim tube, and melted at a low temperature by immersing the tube in warm water. The remaining buttermilk and cheesy matter sunk to the bottom on cooling, and the proportion, by bulk, noted down.

The skimmed milk was gently warmed to 90 degrees after adding a little acetic acid to make it curdle. The whey was separated from the curd by filtration and washing, and the latter dried at a heat not exceeding 212 degrees, until it ceased to lose weight. The weight of the dried curd (pure caseine) when deducted from that of the milk, left as a remainder the weight of the whey.

The following table shows the relative quantities of butter, caseine, (cheese) and whey, the latter includes the buttermilk also :

\begin{tabular}{|c|c|c|c|c|c|c|}
\hline \multirow[b]{2}{*}{ PRTR CENT, } & No. 1. & No. 2. & No. 3. & No. 4. & No. 5, & \multirow[b]{2}{*}{ 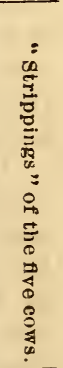 } \\
\hline & 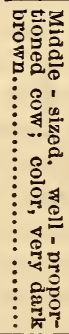 & 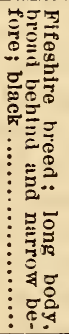 & 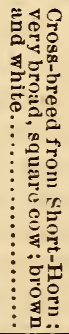 & 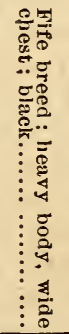 & 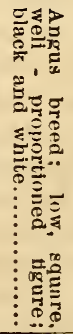 & \\
\hline 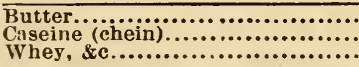 & $\begin{array}{r}4.318 \\
3.017 \\
92.665\end{array}$ & $\begin{array}{r}4.209 \\
3.412 \\
92.379\end{array}$ & $\begin{array}{r}2.401 \\
3.144 \\
93.956\end{array}$ & $\begin{array}{r}3.079 \\
3.389 \\
93.532\end{array}$ & $\begin{array}{r}4.700 \\
3.209 \\
92.091\end{array}$ & $\begin{array}{r}11 ! .102 \\
3.294 \\
86.604\end{array}$ \\
\hline & 100.00 & 100.00 & 100.00 & 100.00 & 100.00 & 100.00 \\
\hline
\end{tabular}

The large proportion of butter in the last drawn milk is seen from the figures in the last column. It indicates 
the truth of the remark we once heard made by a dairy farmer, that the profits of his business depended principally on the perfect performance of the operation of milking.

The quantity of milk daily fiom each of these cows during seven days in the month of July was as follows:

\begin{tabular}{|c|c|c|c|c|c|}
\hline $\begin{array}{l}\text { Daily.... } \\
\text { Weekiy. }\end{array}$ & $\begin{array}{l}\text { Quarts. } \\
\text { No. } 1-93 / 3 \\
\text { No. } 1-68\end{array}$ & $\begin{array}{l}\text { Quarts. } \\
\text { Nu. } 2-12 \% 3 \\
\text { No. } 2-89\end{array}$ & $\begin{array}{l}\text { Quarts. } \\
\text { No. } 3-131 / 2 \\
\text { No. } 3-96\end{array}$ & $\begin{array}{l}\text { Quarts. } \\
\text { No. } 4-102 \% \\
\text { No. } 4-75\end{array}$ & $\begin{array}{l}\text { Quarts. } \\
\text { No. 5-101/3 } \\
\text { No. } 5-72\end{array}$ \\
\hline
\end{tabular}

If we take the weight of an imperial gallon of milk at ten pounds three ounces, the weekly yield per cow of butter, cheese (caseine) and whey would be as follows :

\begin{tabular}{|c|c|c|c|c|c|}
\hline & No. 1 & No. 2 & No. 3 & No, 4 & $N_{0,5}$ \\
\hline $\begin{array}{l}\text { Prod'e per cow } \\
\text { in qts, and Ibs. }\end{array}$ & $\begin{array}{c}68 \mathrm{qts} \\
1733-10 \mathrm{ibs} .\end{array}$ & 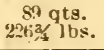 & $\begin{array}{c}9 \text { fiqts. } \\
2443 / 210 \mathrm{~s} .\end{array}$ & $\begin{array}{l}75 \text { qts. } \\
19111 \mathrm{~s} .\end{array}$ & $\begin{array}{l}72 \mathrm{qts} \\
1833 / \mathrm{lbs} \text {. }\end{array}$ \\
\hline $\begin{array}{l}\text { Butter ........... } \\
\text { Caseine .......... } \\
\text { Whey, \&c....... }\end{array}$ & $\begin{array}{r}\text { Lbs. } \\
7.97 \\
5,295 \\
160.496\end{array}$ & $\begin{array}{r}\text { I.bs. } \\
9,540 \\
7,774 \\
209.476\end{array}$ & $\begin{array}{r}\text { Lbs. } \\
7 .(99 \\
689 \\
230.52\end{array}$ & $\begin{aligned} \text { Lbs. } \\
5.81 \\
6.473 \\
178.446\end{aligned}$ & $\begin{array}{r}\text { LA s. } \\
8,6020 \\
5.685 \\
166.895\end{array}$ \\
\hline Total........ & $173.20 \mathrm{v}$ & 226.750 & 244.50 & $191.00 \mathrm{C}$ & 183.400 \\
\hline
\end{tabular}

Of course the caseine in this table does not represent the whole of the cheese which the milk contained, because the process employed to extract it separated the butter entirely from it, besides the cheesy matter was dried to the consistency of horn before being weighed. Common milk-cheese, however poor, and as it is usually made, not only contains a little butter, but also a large proportion of water or wheyey matter.

On the other hand, the quantity of butter given above is no doubt larger than could have been obtained by common churning. Still, the table will serve to show correctly the comparative as well as absolute amount of pure butter and caseine contained in the milk of each cow.

The reader will see from these tables that the cow No. 3, although giving six gallons of milk more than No.5, and seven gallons more than No. 1, jer week, is under both of them in butter, and were it not that the quantity of buttermilk is great, she would fall below them in profit too. Her milk is poor in butter and cheese, and there is reason to suspect that the quality of both is inferior also.

To the inland dairy farmer it is of the greatest consequence to get cows that yield rich milk, even though the quantity should not be so very great, for this reason that the refuse either of cheese or butter making can be turned to little accomnt in such localities. 
CARE.

The success of butter dairying depends so much upon the care and feeding of the stock that no manual on butter making would be complete without touching upon this branch of the business. It is really astonishing what a large difference in the yield of milk it makes by. attending properly to a number of small things in the minagement of stock-things which would seem to many quite too insignificant to be worth observing. The dairyman should have a genuine, hearty love for the animals under his control, attending to every detail for their comfort, providing wholesome, nutritious food, pure water and pure air-everything of this kind in abundance-keeping the animals properly sheltered from storms; feeding always with great regularity; paying the most marked attention to the time and manner of milking, and withal, preserving a uniform kindness and gentleness of treatment throughout every operation, a gentleness extending even to the tones of the voice.

Generally speaking, that cow will do her best that is loved the best and petted the most by those who hare her in charge. If you wish a cow to do her best you must cultivate her acquaintance intimately, and be insparing in little acts of kindness. You may whip and torture a cow into submission, but she will strike the balance against you in the milk pail. One of the greatest faults among dairy farmers to-day is lack of kindness and consideration to domestic animals. Cows should be petted daily, and be made to feel that man is a friend and protector. All pain, fright and uneasiness checks the secretion of milk, and the man who is passionate and abusive to his herd never did and never can realise a full yield of milk from it. I think that any one who has the charge of animals should study their character and disposition. It is an interesting study, and, under the law of kindness, you will not unfrequently bring out wonderful traits and exhibitions of affection, which will show a forethought and design, which may well be ranked with the higher intelligence of reasonable beings.

\section{QUESTIONS FOR DAIRYMEN.}

Every dairyman should have a printed list of questions posted in some suitable place on his premises where his 
family and those in his employ, as well as his risitors, will have opportunity to read frequently. We gire some of them, but the list can be extended:

Do your cows feed in swamps and on boggy lands?

Hare you good, sweet lunning water convenient for stock, and is it abundant and permanent in hot, dry weather?

Have you shade trees in your pasture, or do you think that cows make better milk while lying down to rest in discomfort in the hot broiling sun?

Do you use dogs and stones to hurry up the cows from pasture at milking time, thus overheating their blood and bruising their udders?

Do you cleanse the udders of cows before milking by washing their teats with their own milk, and practice further economy by allowing the droppings to go into the milk pail ?

Do you enjoin upon your milkers to wash their hands thoroughly before sitting down to milk, or do you think that uncleanliness in this respect is not important for milk that is to be treated for butter-making?

When a cow makes a misstep while being milked, do you allow your milkers to kick her with heary boots, or to pound her orer the back and sides with a heary stool, accompanied by sundry profane remarks addressed to the cow to teach her manners?

Is the air about your "milk barn" or milk house reeking with the foul emanations of the pig sty, the manure heap, or other pestiferous odor's?

Good, fiesh, clean water, and in abundance, is one of the most important requisites for milch cows, and it should be in convenient places, where stock will not be required to travel long distances to slake their thirst. If springs and running streams cannot be had in pastures, a good well, with windmill and pump, makes an efficient substitute, and the waste water may, if necessary, be conducted back into the well, so as to keep up a constant supply of good, fresh water.

BRIEF SLMMART OF ITEMS IN THE MANAGEMENT OF MILCH COWs.

The following summary of items, written recently by Mr. A. L. Fish of Herkimer County, widely known as 
one of the most successful practical dairymen of New York, gives the result of the experience of his life in the treatment of dairy stock. They will be found of value :

\section{THE "MILKING-HABIT" EDUCATED.}

All profits obtainable from the cow in milk depend upon her constitution and physical economy in appropriating a portion of her food to thrift and milk. Her faculty of appropriation is developed and fixed in the constitution by usage and habit. In her wild, uncultivated state she yields a small amount of milk to sustain her calf till its second and third stomachs are sufficiently developed to digest plant food, when she weans it by instinct, and her milk ceases to flow. Any deviation from that habit must be developed by incessant milking and proper adaptation of food to make a supply of milk proportionate to the demand. Thus it is upon the principle of demand and supply that her faculties are educated to a high degree of fluency in milk. If cows are milked in cold weather, they should be housed and kept comfortably warm, that their vital forces may be employed to convert food into milk rich in cream, instead of the fatty portions being used up by combustion to keep the animal heat of the body at the required temperature (98 degrees), the point fixed in her physical organism for health.

If she is unaccustomed to higher feed than hay, a change must be carefully made with light feeding, gradually increasing as the system becomes inured to it. Her digestive organs require systematic training like the muscles of the pugilist or race-horse. A proper adaptation of food to the lacteal system is first in the order of training. Succulent food is bettei adapted to lactescence than grain. If grain is fed in the milk season, it should be cooked and made into thin slop or porridge, that it may readily assimilate with the lacteal fluids of the system, So susceptible are the lacteal faculties of cultivation, that heifers from deep-milking mothers have been brought to a good flow of milk under $t$ wo years old, without impregnation, by continued usage of the udder and teats like milking habits. It should be kept in mind that feeding more than is appropriated to the object desired goes to waste by passing off imperfectly-digested or being taken up by other than the lacteal functions. It, therefore, behooves all who 
keep cows for dairy or family use to closely observe the effect of various kinds of food, as some will appropriate to a different purpose than others, by force of habit.

\section{DOCILITY OF TEMPER-HOW ACQUIRED.}

Docility of temper, like lactescence, may be cultivated and established constitutionally, and is as surely transmissible to posterity as color, size, shape, \&c. Uniform kindness in handling, in care and general treatment, with easy access to good water, good feed and good fences, are essential to confirm docile habits. Adversely will detestaable habits be confirmed. Harsh, scarey treatment in handling, hurrying them out of narrow stanchions, to pinch and bruise their ears, tear off a horn or break a neck (each of which I have had done), poor feed, poor fences, scanty water, and poor milkers, are appliances to fit a cow to graduate, where she may be turned into a drove and sold among strangers.

\section{JERKING OUT OF THE STANCHION.}

To prevent cows from acquiring a habit of jerking back ont of the stanchion (by which they are liable to be seriously injured), set them on a slant toward the falling sides, so they will fall back quickly from their neck by their own gravity as the latch is raised to release them, and let the drop bar fall back wide enough that the horns will not eatch on backing out.

WATER NEEDED AFTER SALTING.

Care should be taken that they have salt twice a week, and that they have access to water soon after taking the salt, because salt in its crude state is poisonous and will create a high fever in the stomach, unless diluted by water, which relieves the animal from burning thirst.

BREATHING FOUL AIR.

It is becoming a universal custom to milk. through the season in wintering stables that are constructed to economize room and keep the inmates warm. That. is all right in economy if not carried too far. If too many are crowded into illy-ventilated apartments the air becomes vitiated and unfit for respiration, because it is breathed over and over again after it has passed through the lnngs and been robbed of its vital power. Food once taken into the stomach and passed through the digestive organs is 
repugnant to all animals, and if forced into the stomach will cause disease and death. It is a fact not to be ignored that animals and insects whose life is sustained by inhaling the oommon atmosphere, must have a change of air or death ensues. If stables are not tight enough to cause immediate death, they may weaken the vital forces of the inmates and thus predispose them to disease.

RESULT OF CROWDING TOO CLOSE IN THE STABLE.

If cows are packed too closely in stanchions they will lie against each other and get too warm; then when turned out in very cold weather the change is too great, and when lying down to rest the center cow (of three) is often compelled to stand till others rise, and they are irritated by each others' horns. All these are annoyances that tell upon their constitution, but they may be avoided by giving each cow four feet wide standing room, and addmuch to convenience in milking.

\section{VENTILATION.}

Proper ventilation is indispensable to health of cows both summer and winter, and to eleanliness in milking. If stables are without ample openings over the cows' heads, the pressure of air from without drives the noxious odors firom their voidings, and the venomous exhalation, perhaps from old stale urine under loose, squashy floors, forward to their heads, where they are compelled to inhale them. Such stables are unfit to milk in because the milk while milking will imbibe those odors and unfit it for good cheese or butter. From my observations in searching for causes of the ailments that cows are liable to, I have come to the conclusion that more disease is generated by venomous atmosphere in damp, ill-ventilated stables than all other causes. As a preventive I would advise that the floor of the stable be laid upon a solid bed of earth and gravel, with a fall of six inches in twelve feet from the stanchions, with the same ratio of descent, to a point for outlet of liquids, with a platform raised six inches for cows to stand and lie on. The floor and platform plank should be bedded in water-lime mortar, so there shall be no soaking down nor hiding-place for stale urine to deposit and generate venomous odors.

Openings in the sides of stables are useful in warm, still weather, and to dry and cleanse them, but should not 
be relied on for breathing air, for they should be closed in severe weather to prevent currents of air striking the inmates, which should always be avoided. An opening forward and over their heads large enough to fodder through the whole length of the stable is little room enough for circulation of breathing air, and would not draw through in currents unless the siding is open below and too airy above.

\section{WATER.}

Cows will drink twice a day and oftener if an opportunity is offered, and it is better than to drink a large amount at once. If cows in milk have water but once, they should be slopped morning and evening to increase the flow of milk.

FIRST TURNING TO GRASS.

Cows should not be allowed a full range of pasture till there is a supply of grass, because they will acquire a roving habit, and their unnecessary travel will pack the soil and destroy much grass. When first turned to grass they should be allowed only a limited range between the usual hours of feeding hay. This hay feed, of the first quality, should be continned till they refuse to eat it. This keeps up their strength and avoids too sudden change in the habits of digestion.

CLEANSING THE BLOOD.

After parturition, one table spoon full of sulphur should be given to each cow twice a week, to cleanse the blood of any impurities that may he lurking in the system which are liable to settle upon different organs, causing garget, horn-ail, hoof-ail, or a morbid condition of the genèrative organs, by reason of which many cows go farrow, or are predisposed to abortion.

\section{SALTPETER FOR GARGET.}

If symptoms of garget appear, one tea spoon of saltpeter once a week is good. When the season arrives for turning with the bull, this should be discontinued. Salt three mornings and skip three for two weeks.

\section{COMING IN MILK.}

To bring them into milk nearly the same time the next season, cows should not be allowed to worry with other cattle after being turned with the bull. 


\section{GRAIN FEEDING AND GIRASS.}

No profit will accrue from grain feed in flush of grass feed. When it diminishes, its equivalent should be kept up by soiling or otherwise, for if the flow of milk is allowed to decrease to a great extent, extra feed late in the season will be appropriated to flesh instead of milk.

If cows are to be turned into clover, it should be done after the sun has aided the plant to elaborate the gases of night-fall.

\section{REMEDY FOR HOVEN.}

In case of hoven, a quarter of a pound of soda dissolved in a gallon of water, and poured down is an effectual remedy. Should the case be severe and require instant relief, plunge a butcher knife into the paunch on the left side behind the last rib near the back, at the point where the paunch adheres to the back and ribs. There is no danger in opening the paunch there, because it would not let its contents out into the body. Keep the hole open with an alder, quill, or hollow stick, secured from dropping into the paunch, till the medicine in the stomach takes effect. Hoven is often mistaken for choking. If a choke can not be felt in the meat pipe, it may be determined by crowding a "tarred" rope, one and a half inch in diameter, down the creature's throat. Such a rope, four feet long, with a sailor's wall knot on each end to crowd against the obstacle in the throat, should be possessed by every farmer owning a herd of cattle. Any vegetable that a creature can swallow into the meat pipe may be pushed into the stomach with such a rope with safety, after pouring down a pint of soft soap.

In closing my remarks on the care and treatment of milch stock I cannot do better than present some facts in regard to-

THE EFFECTS PRODUCED ON THE MILK FROM

ILL-TREATMENT OF COWS.

It is only quite recently that the subject of milk poison has begun to claim attention. Farmers and dairymen are for the most part incredulous concerning changes liable to be wrought in milk, as a consequence of the manner in which stock is treated. If a farmer beats or otherwise maltreats his cows, he may perhaps admit, 
when his passion has become sobered, that the animals, under bad treatment, will yield a diminished quantity of milk; but that the milk from this cause is rendered less nutritious, or is so changed as not to be a healthful article of human food, is regarded as preposterous.

No greater service, it seems to me, can be done for the dairy public, or for the community at large, than to disseminate correct information in regard to the various causes affecting the healthfulness of milk. And I am glad to see that the subject is arresting the attention of medical men, because when they give the result of their investigation on questions of this character it carries with it the weight of authority and is more readily believed than when it originates from other sources.

We cannot expect a change of practice or reform unless men are convinced of their errors. A mere statement of facts, if they do not carry conviction to the mind, will effect but little; hence, in presenting the following account of the diseases resulting from the use of imperfect milk and the causes which led to its imperfection, $I$ am glad to present the subject from a medical stand-point, or as coming under the experience of a well known practitioner of medicine. The facts given I have condensed from an article in a late number of" the "Medical and Surgical Reporter," by Dr. T. D. Crothens of Albany, N. Y.

'The latter part of October, 1874, and since the publication of the article referred to, I had an interview with Dr. Crothers and obtained from him many of the circumstances connected with his investigations, and I am of the opinion that the conclusions arrived at by him are substantially correct. Indeed, they correspond with facts coming under my own observation and experience.

\section{DISEASED MILK CAESED BY FILTHY STABLES}

\section{AND ROTTEN VEGETABLES.}

Referring to the almost universal use of milk as a diet, and the many cases reported during the last year, which give strong evidence that milk is an agent of far greater danger and more widely diffused as a source of disease than we are aware of, Dr. Crothers describes a severe case of diarrhea occurring in a healthy family and living in good hygienic surroundings. Called to prescribe for the sufferers, he found that the family had never suffered 
from this disease before, and it seemed more violent among the younger members than in those grown up. A careful inquiry into the habits of this family indicated nothing unusual, except the free use of milk as an article of food. Sunday, milk was made a prominent dish at dinner, and it was noticed that the days following the disease was increased unless checked by medicines. The milk came from one cow kept in the neighborhood. Suspecting the milk was not all right, Dr. C. found on visiting the stable that the cow was a small, ill-conditioned animal, standing in a close, filthy stable, ill-ventilated and containing hardly room enough to turn about. The food of this cow was garbage from the street, consisting of vegetables in all degrees of decomposition, cooked and raw, alternated with brewers' grains once per day. Water was given in the food, but occasionally, depending on chance, a pail was brought in. The stable was cleaned once or twice a week, and the doors were closed to keep in some hens. The walls of the building were brick, and the ventilation or renewal of the air must come from the open seams in the door and window. In this place for over three months this cow had been confined, her body was filthy and her hair stood up in all directions. That the milk was impure and the cause of the diarrhea was proven by the complete disappearance of the disease when the family stopped using the milk.

THE NATURE OF THE POISON UNCERTAIN.

Dr. Crothers thinks the nature of the poison is uncertain, and he refers to the investigations of Dr. CHANDLER of New York, who failed to find any specific poison in milk known to be impure. In this case the impure milk acted as an irritant, causing a low grade of inflammation - a certain forerunner of other lesions.

\section{DEATH FROM USING IMPURE MILK.}

This was the case of an elderly gentleman, previonsly well and strong, who, while convalescing from a severe attack of intermittent fever was ordered to use milk freely by his physician. Four days after he began to use milk as a medicine, he was attacked with exhaustive diarrhea, resisting all medicines and terminating fatally in six days. The family of the owner of the cow from which the milk 
was furnished likewise suffered from diarrhea. The cow was kept in a similar way to that first described; and when this cow was turned out in the yard and received better food and more cleanly surroundings, the diarrhea in the family disappeared. Another severe case of the same complaint was noticed in a middle-aged man using the milk of swill-fed cows. The disease terminated in death after four weeks.

\section{INFLUENCE OF INSUFFICIENT FOOD ON MILK.}

Some remarkable experiments on this subject were conducted by M. Decaisne of Paris, during the siege of 1871, and detailed in a paper before the French Academy; prefacing his paper with observations of Dumas, Paren and Boussingault, in which were shown the fact that a cow gave healthy milk in exact proportion to the surplus of food beyond what was necessary for its own maintainance. If the animal was kept upon food barely sufficient for proper nourishment, the milk produced must be at a loss of animal tissue, with general deterioration of the milk and also of the cow. Milk formed at an expense of the nutrients and tissues of the body has less caseine, butter, sugar and salts. while the albumen will be increased. It follows that the value of milk must depend upon the excess of food beyond what is required by nature to keep up the normal vigor of the body.

DeCAISNe shows that nearly an analogous condition exists in women, which he demonstrated by experiments during the siege of 1871 , in 43 cases of nursing women. These cases were in private families and suffered from the want of iusufficient nourishment. Some of the results of his observations are stated thus:

Insufficient food always produces a diminution in the normal quality of the milk, also a variation of its chemical constituents, such as an increase of albumen and diminution of caseine, butter and sugar. The proportion of albumen, in such cases, is generally in inverse ratio to that of caseine. The health of the mother declined with this variation in the quality of milk, depending upon age, hygienic conditions, constitutional vigor, \&c., until the milk became minimum in quantity and quality. Also, that these effects are seen in four or five days from the time of using an insufficient diet. 
TYPHOID FEVER GERMS COMMUNICATED THROUGH MILK.

An epidemic of typhoid fever which occurred near Glasgow, Scotland, in 1872-3, indicated the prevalence of this fever in 32 out of 39 families which were supplied with milk from one dairyman. Families supplied by other milkmen were singularly exempt. The family of the dairyman were also attacked, particularly those who had used the largest amount of milk. The fever germs were supposed to have been propagated through adulterating the milk with bad water, and probably by allowing or forcing the cows to slake thirst from impure water.

Again, in one of the healthiest suburban sections of London, 500 cases of typhoid fever were found distributed in 104 families, 96 of which were supplied with milk from one dairy. The contagion was traced directly to the water used for washing the milk cans and retained in the milk, the water being previously polluted by sewer drainage.

\section{MILK POISONED BY ANIMALCUL 2 .}

Cases marked by violent cramping and purging have been traced to the milk used, which was found to contain animalculæ, supposed to be taken up in the drinking water and developed in the system. Dr. Brown, of Gault, Ontario, reports in the Canada Lancet two very striking cases of this kind. VogLe, years ago, showed that vibriones in human milk arose from a condition of mal-nutrition. Dr. Gibis found two genera of animalculæ present in milk, when the health of the mother was disordered by prolonged lactation. Other authorities have shown that milk may contain animalculæ as well as poisonous germs equally dangerous.

MILK POISONED FROM VIOLENT EMOTIONS OR SHOCKS OF THE NERVOUS SYSTEM.

A familiar illustration is that of milk, when the mother is violently agitated, causing convulsions and death in the child. The text books give particular caution on this point; yet an hour after, when the emotions have subsided, the peril seems to have passed away. We are yet iguorant of the nature of this poison, which seems to have such a peculiar action on tbe nervous function. Dr. CroTHERs instances a case at a late clinic at the Albany Hos- 
pital, of a child six years old suffering from epilepsy. The history indicated that the child was in health up to a certain, time when the mother, laboring under intense excitement, put the child to her breast; soon after the convulsions came on, which developed into a full case of epilepsy.

A case of chorea recently, under Dr. C.'s care, he says can be traced back to nursing the child when the mother was violently excited. Other cases have been noted of feeble and broken-down nervous systems in children, which were referred back to the same cause.

HOW BRUTAL TREATMENT OF COWS AFFECTS THE MLK.

A gentleman of Albany was advised to secure the milk of a young, blooded cow for his infant child. A cow whose first calf was ruming by her side was purcliased, and the calf taken away, and his servant was ordered to milk her, bringing the milk direct to his house. Two months later this child, who was previously healthy, was broken out over the body with a strange, undefinable rash, which finally developed into pustules, called by the physician scrofula. Following this came a ferer, which seemed to affect the brain and nervous system. In the meantime, the bowels suffered from intestinal irritation, alternately constipated and relaxed. The child, for a year or more, while using the milk, was under the constant care of physicians, and after the second year had a weak, broken-down nervous system, with frequent pustular eruptions over the body.

Subsequently it was ascertained that this cow was driven into a close stall, and whipped into subjection, to allow the milking to go on, and, for the entire season, this process was one of force and more or less brutality. Under these circumstances the milk was made poisonous by the nervous condition of the cow.

Another instance came under the observation of $\mathrm{Dr}$. Crothers. It was that of a farmer who, by the advice of his physician, procured the milk of an Alderney cow, on account of its supposed richness. This cow, from her vicious habits, had been considered unfit for the dairy. The milking was attended with much excitement, and the child to whom the milk was given suffered from gastrointestinal irritation and what were called scrofulous ulcers, 
during all the time of using the milk. Two years later this child was presented at the Albany Hospital clinic with symptoms of chorea, a weak nervous system, and low tone of physical vigor-an exception to other children of the same family. Other cases are given of serious diseases arising from the use of milk from cows brutally treated.

INPORTANT CONSIDERATIONS IN THE CARE OF STOCK.

Dr. Crothers, from all the facts observed, comes to a series of conclusions, some of which we give as follows: 1. Milk coming from ill-nourished, half-fed cows, having, no surplus of food beyond minimum requirements of nature, is injurious, and may be a source of disease. 2. Cows deprived of abundance of good water, ventilation and exercise, secrete impure and dangerous milk, which may be loaded with gases, animaleulæ and fever germs. 3. The milk from old, debilitated cows fed on grains or over-stimulating food is also imperfect and unhealthy to a variable degree. 4. The nervous condition of the cow at the time of milking determines the purity of the milk. If this is neglected, the milk is an active source of disease, positively dangerous and fatal.

In conclusion, he says that facts show that milk is the prolific source of many diseases now obscure, and unless careful inquiry is made into the condition and surroundings from which we receive our supply, we neglect a sanitary measure of great importance.

I should be glad to have every dairyman in the land read this statement and consider how far the facts herein given will apply to cases coming under his observation or experience. The questions presented, it seems to me, are of grave importance.

\section{FEEDING.}

Different kinds of food have more or less influence on the flavor of milk. Some kinds are much more efficient than others, not only in promoting good flavor in the milk, but in maintaining health and thrift in the animal. For butter-making it is essential that the cows have an abundance of rich and nutritious food. Cows giving milk require more food than when not in milk. A certain amount of food is needed to support the animal, and a 
surplus above that must be consumed and assimilated to make milk. Food should be abundant and easy of access, because much traveling or exercise in obtaining it checks the milk sesretion, the food going to supply the waste of tissue lost in extra labor rather than for milk. Cows should always be kept in good flesh and condition, because, if from inclement weather or other causes there be a slight interruption in the usual quantity of food, the good-conditioned cow has a store of fat-laid up in the system that will bridge over these short periods without feeling the loss so sensibly as the cow thin in flesh, which has no surplus fat to spare.

I know of no better food for milch cows than rich, old upland pastures, where there is a variety of grasses, and the turf is thickly set with grass, showing no intervening spaces. Rich old pastures, clear of weeds, where the herbage is thick, sweet and nutritious-where a cow can get her fill without much labor-where good, sweet water is convenient-where there is shade under which she can rest and ruminate these, in my opinion, will be about the best conditions in which the animal can be placed for yielding much and very fine butter. Under such circumstances I do not think any profit will be realized by feeding ground grain, or meal of any kind, as a supplementary food. There is a great difference in pasturage, and the trouble with dairymen is, that they do not discriminate closely enough as to the quality of the grasses that make up the pastures on different farms.

The coarse, sour herbage of low lands or swalespastures foul with weeds or abounding in grasses having a large percentage of woody fiber are not calculated to give satisfactory returns. And in all cases where pastures have depreciated, and afford a scanty supply of nutriment, they should be supplemented by giving the cows a daily ration of bran, ground oats, or some other food, to supply the deficiency.

\section{VARIETIES ESTEEMED FOR BCTTER-DAIRYING.}

On the old pastures of the best butter districts there are several varieties of grasses that spring up spontaneously, and are much esteened as affording sweet and nutritious feed, and from which the best qualities of milk and butter are produced. They embrace the June or 
Kentucky blue grass (poa pratensis), the foul meadow grass, (poa serotina), meadow fescue (festuca pratensis), red top (agrostis vulgaris), the wire grass (poa compressa), the sweet-scented vernal and vanilla grass, orchard grass (dactylis glomerata), together with timothy, clover, and other forage plants.

The June grass is regarded as very valuable; it throws out a dense mass of leaves, is highly relished by cattle, and produces milk from which a superior quality of butter is made. It is found growing throughout the butter districts of the country.

The Wire grass is deemed one of the most nutritious of the grasses, is very hardy, eagerly sought after by cattle, and is one of the best grasses for fattening. Cows feeding upon it yield milk of the richest quality, from which the nicest butter is made. It flourishes well upon gravelly knolls and in shady places, and its stem is green after the seed has ripened.

The Meadow fescue is common in old grass lands where the sod is thick, and grasses of different varieties are mingled together. It starts up early in the spring, is relished by stock and furnishes good, early feed. The milk farmers hold it in high estimation as a reliable grass, tenacious of life and not rumning out like timothy or clover. The white clover springs up spontaneously in the old pastures, and is esteemed as giving flavor and quality to butter.

The sweet-scented vernal grass grows best upon moist soil of old meadorrs. It starts very early and gives off an agreeable odor.

Orehard grass is one of the earliest as well as most nutritious and productive grasses. It is exceedingly palatable to stock of all kinds, and bears cropping close. It is a most valuable grass, and should enter largely into all mixtures intended for permanent pasture.

Mr. Daniel Bachelor of Utica, N. Y., who has håd considerable experience in introducing the best mixtures of grasses, both for pasture and meadow, says of the sereral pasture grasses for our climate: "I know of nothing better than our native June and orchard grasses mixed with bent grass, crested dog's-tail-and meadow fescue; for after all, it is the hardy grasses that we want, and none other. Of the artificial grasses, as those plants are 
called which are cultivated in England, and used like the grasses, there are many kinds-annual, biennial and perennial, legumes and brassica, some of which are not hardy enough for our climate. Lotus, sainfoin, parsley, saradella and yarrow cannot be successfully grown here. Rape, mustard, lucerne and vetches can be grown here as easily as clover. But at the head of all leguminous plants stands the alfalfa or lucerne, which is destined, I believe, to greater success in this country than the red clover, especially in the hot, dry soils of the WVest and Southwest; as it will withstand drouth and heat, look fiesh and green when all other forage plants are dry and drooping. Lucerne has been known to old world agriculture for the last two thousand years, and perhaps longer than that. It is a hardy, herbaceous perennial, and will send down its long roots into mellow subsoil to a depth of ten or twelve feet. It is very tenacious and will take possession of the soil to the exclusion of all the grasses and herbaceous plants. Notwithstanding the large amount of forage it produces, the lucerne does not exhaust but improves the soil, for the leguminosa draw almost their entire nutrition firom the atmosphere, and the lucerne produces ten times more roots than any of the clovers. Vast masses of these roots decay in the suil every season, thereby enriching the land. The plant, too, is so dense that it shades the soil. That lucerne will flourish in this region (Central New York) is proved by the fact that Messrs. Walcott \& Campbell have grown it for many seasons and prefer it to any other forage plant.

"I take theliberty, in conclusion, to say that no matter" what seed is sown, unless the soil be kept in good heart both pasture and meadow will fail. Johnston shows that for every ton of hay carried off the farm, there goes with it not less than one hundred and forty pounds of silicates, phosphates and potash. Now, if these ingredients are not returned in some shape to the land, the crops wiil fail; moss, sorrel and wireweeds will usurp the ground, and barreuness take the place of fertility."

\section{THE GRASSES APE SOCIAL.}

The grasses, so to speak, are social in their character, and thrive best when different kinds are grown together in the same sod. The practical farmer, then, should un- 
derstand this fact and take advantage of it in laying down grass lands if he is seeking for the largest product; as it is well known that individual plants of the same species will not grow close to each other for any length of time; for, however thickly planted from seed, in one or two seasons intermediate plants decay and leave vacant spaces which are soon filled up with spurious grasses, weeds or moss. But when a variety of different species adapted to the soil are mixed together they grow close, form a dense bottom and continue permanent.

\section{$\Lambda$ DIFFERENT ORDER OF SEEDS FOR PASTURES THAN MEADOWS.}

In seeding for pastures a different order of seeds should be used than for meadows. In pastures we seek to have those varieties that spring up in succession, so that a good, fresh bite may be had from spring to fall.

For meadows, on the other hand, we seek plants that will come to maturity at about the same time, otherwise a portion of the plants are cut too early or too late, and thus loss is entailed.

\section{OVER-STOCKING.}

Many dairymen habitually over-stock their pastures, thus not only doing great injury to the grasses, but the cows, from an insufficient quantity of food in a given space, are required to travei long distances in quest of food, and thus the yield of milk is diminished. By this practice the roots of the grasses and the whole plants are kept so small that their growth is feeble, and not onehalf the feed is afforded that the land would prodnce if stocked properly and the grass allowed to get a good, thrifty start. But this is not the only disadvantage to the pasture from over-stocking. The feeble growth of the grasses allows other plants to creep in, and the ground soon becomes overrun with weeds, which, on account of their not being cropped by stock, grow in great luxuriance, maturing their seed and thus impoverishing the soil. The curse of American dairying to-day is weeds. When once they get full possession they become so formidable that the farmer is often disheartened and gives up their eradication. It is always advisable to pull up or exterminate bad weeds on their first appearance in pastures, and not allow them to spread. There are many weeds 
that cows, will eat during a dearth of nutritious food, that give a taint to the milk, and thus are prejudicial to a fine quality of butter. When pastures are over-stocked, or when they are not yielding a sufficient supply of good, sweet, nutritious feed, additional rations should be allowed the cows, such as bran, ground oats, shorts or mill feed, corn fodder, cut grass, or some other forage plant. Some butter dairymen are strong advocates of corn meal as a supplementary feed in summer. Corn meal being of a heating nature, we do not regard it as the best selection in hot weather, and if on account of its low price it is deemed advisable to use it at such times, it should be mingled with twice or thrice its bulk of bran. In this way the elements of milk are supplied in better proportion, while the animals will maintain better health. In cold weather corn meal can often be fed with advantage. In winter and spring roots are exceedingly valuable in keeping up a flow of milk and in maintaining the health of the animal, a point of very great importance, and which must not be overlooked by the practical dairyman who is seeking the best returns from his herd.

\section{COWS SHOULD BE FULL FED.}

What we especially desire to urge in this connection is, that cows should at all times be full fed with sweet and nutritious food. We do not believe in over-feeding, and particularly with rich grains or highly-concentrater food. Dairy stock is often very much injured by injudicious feeding with this kind of food. Besides, it is a great waste to push the animal to consume a large quantity of expensive concentrated food which cannot be assimilated but must be cast off in the excrements. Nothing will be gained in the quality or richness of milk from such overfeeding, since every animal has a structural limit to her milk in this regard which no excess of feeding will improve: It is true, by over-feeding the richness and value of the manure are increased; but as the same elements can be furnished at much cheaper rates from other sources than in the undigested or unassimilated meal and other highly-concentrated food, it would be very poor economy on this score. But when we bring into account the danger of doing injury to the cow, it will be evident that such a course is not to be recommended. The tendency of 
over-feeding is, however, not so great in summer as in spring, or at such times as when the animals deprived of pasturage are upon a stable diet. In summer the main fault among dairymen is under-feeding, from a misapprehension of the capacity of pasture liunds, and, in consequence, over-stocking. A pasture that is over-stocked with but one or two animals, if no additional food is given to the herd to counterbalance the excess of stock, will decrease the yield of milk much more than the average quantity obtained from the excess of stock. In other words, the dairyman, under such cireumstances, would have increased his profits had he in spring selected out from the herd two of the poorest cows and given their milk to some neighbor for their pasturage. But the true course in such cases is to supplement the feed, making up the deficiency occasioned by over-stocking.

\section{WINTER DAIRYING.}

Somewhat recently the plan of winter dairying has been suggested, and is strongly advocated by a few persons who claim to have thoroughly tested the matter; and prominent among these is $\mathbf{M r}$. Bores of Marengo, Ill., who has a herd of about 130 cows employed in butter dairying. The plan is to have the cows "come in milk" during the fall, to feed high during winter and then in spring, when the animals naturally begin to fall off in milk, the May and June pastures send them up to nearly their full yield again. Later, as the summer drouth occurs, or as grass begins to deteriorate, the cows are "dried off" and take their rest preparatory for the next calving. It is claimed for this system that cool weather is more favorable for the manufacture of butter than the heat of summer; and as the butter market is generally better in winter than in summer, together with less risk to butter in the transportation, these considerations have weight in favor of the system. On the other hand special provision, it would seem, must be made for keeping the cows in warm quarters, well ventilated, together with an ample supply of succulent food, roots, \&c., while the labor of milking and the manufacture of butter in all its details must subject the operators to more or less exposure to cold weather, thereby rendering the work less agreeable than in warm weather, to say the least. 
MR. BOIES' PRACTICE.

As Mr. Bores has been a very suceessful operator under this system, it may be of interest to give a brief account of his practice as detailed by him to Mr. J. H. REAL, a well-known butter dealer of Philadelphia. Mr. Real says he knows of no one who has produced better butter or who has made more money out of the business in the same length of time than Mr. Bores, and we quote from a recent address of Mr. Real before the New York State Dairymen's Convention at Binghamton, in which he gives Mr. Bores' statements concerning his practice, as follows : "My father and I commenced the dairy business five years ago, without any capital, except our cows. We started with thirty - five cows, and shipped our milk to Chicago, in regular milk cans; but finding it very costly, we began making our milk into cheese the following summer, and in the succeeding year commenced making butter. At first we put it up in pound lumps and shipped to Chicago once a week. This butter realized us 24 cents per pound. That summer we bought a dairy of milk in addition to our own dairy, and in the following season contracted for one more. Each year since we made additions, until at present we take the milk from over 400 cows, and have 135 cows of our own and a farm of 300 acres in a high state of cultivation. We have also made additions to our milk-house every year, and now work up 17,000 pounds of milk per day. The milk-house is 24 by 40 feet, and our workroom 20 feet square.

"We dry our cows off about the first of July, and have them come in fresh in the fall of the year instead of drying them off in November, as is the general practice. We give our cows the most nourishing kind of food and find it almost impossible to dry them off on account of its richness. The quality of the feed makes a very great difference in the quality and yield of butter.

"We always milk our cows at the same time of day. In the morning we give each cow four quarts of meal, and do the milking while they are eating, after which we give them a very small amount of salt, perhaps a teaspoonful. We also give them a quart of oil meal every day, to assist digestion. After we are done milking and the cows have finished eating, they are let out to drink. The water is always warmed in the winter. 
"When the weather is pleasant and warm, the cows are let out in the sun for three or four hours during the middle of the day. When brought in they are fed with early-cut hay. Our hay is cut early, in order to retain its natural sweetness. At five o'clock in the afternoon we give each cow five quarts of corn and oatmeal mixed together, and then milk them again.

"We are very careful abcut our stables, and enforce strict quietness in them. No striking or pounding of the cows is allowed; they are always driven quietly. We keep them warm, but avoid too high a temperature. A number of cows in a very warm stable produces an unhealthy atmosphere. We consider that there is more danger of the stable being too warm than of its being too cold.

"The milk is delivered from the surrounding dairies to our factory twice a day, morning and evening. In the morning it is taken into the milk-house and strained into three large pans, each of which is 13 feet long, 4 feet wide and 9 inches deep.

"We keep the thermometer in our milk-room from 60 to 65 degrees Fahrenheit. We consider it better to let the cream sour before churning, for the reason that the butter is a good deal more solid, and a larger quantity and a better quality result from sour cream. We churn every day, Sunday excepted. We use three-quarters of an ounce of salt to a pound of butter.

"Our butter is taken directly from the churn and laid upon a white ash butter-worker and placed in a cool cellar, being washed before taken firom the churn."

He affirms that it does not require nearly so much milk to the pound of butter in winter as in summer; that the difference, according to his experience, is full 25 per cent. in favor of winter milk; that cows would not give any more milk in summer than in winter if properly taken care of, while in winter we get better prices for butter. He said their cows produced on an average 300 pounds of butter each per annum; that the manure from cattle taken care of by his system is of the most valuable kind, almost equal in strength to guano.

Mr. Real adds that he knows that Mr. Bores, as well as others in his locality who pursue the same plan, produce the finest kind of butter, and that Mr. B. has attained 
a position as a representative dairyman second to none other in the country. Mr. Bores, he says, supplies the best hotels in the United States regularly with his butter and rarely ever sells a pound under forty-five cents.

Having presented the main features of this system, the question need not be discussed further, since every practical dairyman will see its advantages and disadvantages, and will adopt or discard the system as it best suits his views and his corvenience.

\section{MILK IN ITS PHYSIOLOGICAL AND CHEUICAL RELATIONS.}

Of milk, Dr. Abernethy was accustomed to say, it was "the most nutritious of all things." Prout designated it as "the true type of all food." Gosse claims milk among the most easily-digested articles of food, which include, according to him, substances which are converted into chyme within one to one and a half hours. Of all the secretions which are elaborated from the blood there is none which comes so near it in chemical composition as milk. It is almost the only food which will, when used alone, support life and maintain health and vigor for an indefinite length of time, and Dr. Carpenter, in his Manual of Physiology, observes that milk being an admixture of albuminous, saccharine and oleaginous substances, indicates the intention of the Creator that all these should be employed as components of ordinary diet. Besides this mixture of nitrogenous and ron-nitrogenous matters so essential to the maintenance of life, the saline or mineral matters which milk also contains, especially the phosphates of lime and magnesia, are no less necessary to the growth and development of the young animal.

Milk, as is well known, is a glandular secretion peculiar to the mammalia. It is a whitish, opaque liquid, of an agreeable, sweetish taste and a faint but peculiar odor. Its specific gravity fluctuates, according to Scherer, between 1.018 and 1.045, but, according to Voelcker, cows' milk of good quality has a specific gravity of 1.030. 
Milk is essentially an emulsion of fatty particles in a solution of caseine and milk sugar. The fatty matter is not contained in it in a free condition, but enclosed in a little cell. The membrane forming the walls of this cell, is suvposed by some authors to be caseine, a substance which is also found in a state of solution in the milk. Others have ventured the opinion, that this investing membrane consists of an albuminous substance, the composition of which has not, as yet, been-defined. When examined under the microscope, without the addition of any chemical reagent, these globules exhibit no trace of any investing membrane, although its existence has been demonstrated beyond a doubt.

Draper affirms that caseine may be separated into two parts, one containing sulphur, and the other not, and he comes to the conclusion that the substance we designate as caseine consists of two ingredients, the proteine compound which exists in a state of solution in milk, and also that which forms the nembrane of the fat corpuscles. These fat globules are of different sizes in different animals, and even in animals of the same kind they vary from the 1-2000th to the 1-4000th part of an inch.

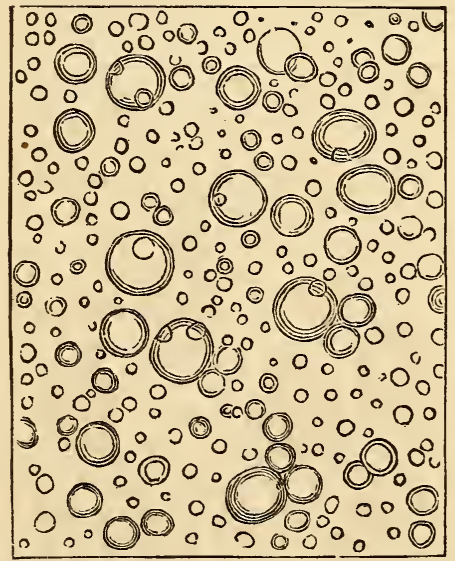

Frg. 1-Microscopical appearance of the milk globules.

The illustration Fig. 1, gives the ordinary appearance of healthy milk when examined by a highly magnifying power. In proportion as milk is rich in butter, so are the globules present in increased number and size. The color and opacity of milk are both due to their presence. As these globules are separated in the shape of cream, the milk becomes clearer, and acquires a peculiar, blueish tint, which is a very good indication of its character. The less transparent milk is the better and more butter it contains. 
Dr. Sturtevant, of Massachusetts, who has recently made some valuable investigations in regard to milk grobules of different breeds, states that the size of these globules is always larger near the time of calving, decreasing in size the longer the time advances from that period, and as the larger the globule the more readily it rises to the surface, we have an explanation why milk that has been set for cream, and skimmed during the spring, or soon after the cows have calved, is so poor. In other words the milk which is less rich in butter during spring than in fall, also parts more readily with its fat, and thus the skimmed milk is comparatively poorer than at any other time.

The cheese-maker may learn from this, that he cannot skim milk with impunity at such seasons. That in fact there is no time when the cheese feels the skimmer so sensibly.

\section{Colostrum.}

The first milk of the cow after calving is called Colostrum. When examined under the microscope, it is found that in addition to the ordinary milk globules, granular corpuscles of a pale yellowish color, measuring from 1-800th to 1-2000th of an inch are present. (See Fig. 2).

The existence of these granular cells imparts a purgative action to the fluid, which is generally viewed as being of great use in assisting in the expulsion of the meconium firom the intestines of the young animal. This peculiar substance accumulates in considerable quantities in the intestinal canal, during the latter period of utero gestation, and it would appear that after birth the stimulating or cathartic action of the colostrum is

required for its removal. colostrum-a.a. Granular corpuscles.

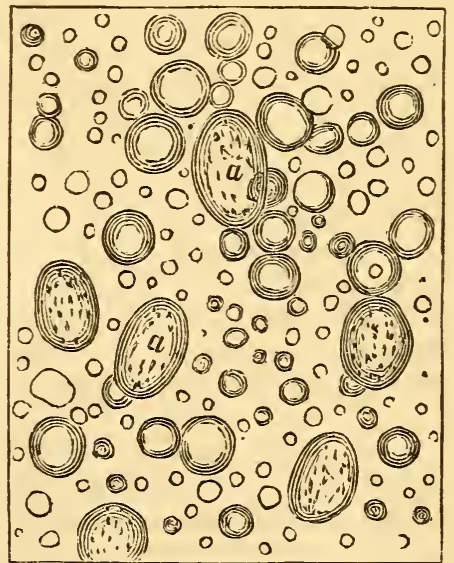


Colostral milk differs essentially from the subsequent ordinary secretion. The colostrum contains a much larger proportion of solid materials than the milk. According to DraPER, the quantity of fat in some cases is nearly double, the quantity of sugar is likewise much greater, but the relative quantity of caseine is less.

On the other hand, according to Voelcker and BousSINGAULT, the colostrum contains an unusually large quantity of curd. Boussivgault gives the following as the

COMPOSITION OF COLOSTRUI, OR FIRST-DRAWN MILK OF THE COW :

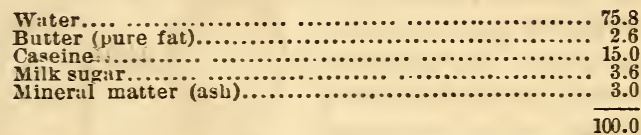

In from eight to ten days after calving this peculiarity disappears and the milk assumes its ordinary condition. Lehyasy describes colostrum as a turbid, yellowish fluid similar to soap and wafer, having a viscid consistence and a strongly alkaline reaction. It passes more rapidly into lactic acid fermentation than normal milk, and it constantly exhibits an excess of solid constituents, both in wo'nz! and animuls, as we learn from Srmox, Chevalifr, and Hexpr. According to the last-named observer, this augmentation is most marked in the easeine in the milk of cows, asses and goats.

Although on microscopical investigation its external appearance would seem to show that colostrum contains less fat, the contrary is proved by the results of most analyses. The colostrum is richer in fat than the corresponding milk. The cause of this striking phenomenon may perhaps depend upon the quantity of fat contained in the granular masses. The colostrum contains, moreover, fiom two to three times more salts than the milk.

\section{SECRETION.}

The secretion of milk, says Prof. Srarovds, forms no exception to the rule which obtains with reference to animal products in general, namely, that it is formed fiom arterial blood. So large an amount of rilik as is well known to be furnished within a few hours by the cow 
necessarily requires a corresponding quantity of blood for its secretion. We find, therefore, that the arteries going to the udder are both large and numerous, and the branches of each vessel freely anastomose together, so that no interruption to the regularity of the supply of blood to every part of the gland may take place.

The anterior portion of the mamma receives its blood chiefly from the internal pectoral arteries, which, quitting the chest, run in a backward course to reach the glands. The posterior parts are supplied principally by branches called the nammary arteries, which come off from the epigastric artery. In addition to these, the circumflex artery of the ileum sends numerous branches to the giands, which likewise anastomose with the other vessels. The several vessels which come off from these trunks penetrite into the substance of the mam-

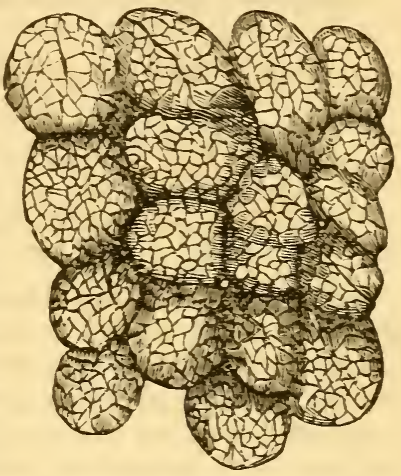
mæ, within which they firee- Fig. $3-A$ highly magnifed riew of ly ramify by numerous di- $\begin{gathered}\text { the cecal extremities or follicles } \\ \text { of the lactiferousducts in which the }\end{gathered}$ visions and sub-divisions. secretion of milk tikes place.

Ultimately, by further splitting up, and consequent diminution of their caliber, they form ressels so minute as to be unobservable to the naked eye, and which have been designated capillaries. These are distributed to the follicles, or cœcal extremities of the lactiferous ducts, upon which they form a minute rete of vessels, and furnish blood, both in a sufficient quantity, and also in a condition fitted for the secretion of milk. The cut (Fig. 3) represents the cocal extremities of the lactiferous ducts, highly magnified, and surrounded by their net-like structure of capillaries.

From the cocal extremities the milk, as quickly as it is formed, finds its way along the minute excretory ducts to which they are attached, into large tubes, and thence into various sized cavities, which are termed reservoirs. The arrangement of this portion of the gland may be compared to bunches of currants, as connected with, or 
growing upon, their foot-stalks. The fruit would here represent the milk-secreting follicles, and the stalks the tubes by which it is conveyed away. Fig. 4 will convey a clear idea of this structure. The lactiferous or excretory ducts are here marked $a$, and milk-secreting follicles $b$. From the smaller sized reservoirs which are shown in Fig. 5 the milk passes through numierous canals into the large reservoir of the gland which is sitnater just above the teat. (See $a$. Fig. 5.) Here it is detained in considerable quantity, often to the exFig. 4-Arrangement of the tent of two or more quarts, says Prof. Srmonds, until drawn off by the sucking of the calf, or by the act of milking, which not only empties the large, but all the other reservoirs and milk ducts.

In regard to the size of the large reservoir situated just above the teat, authorities differ. Some make it of a size holding from less than a gill to a quart, and Dr. Sturtevant affirms that in his dissections of the udder he has never found it more than an inch and a half in dianeter. It will thus be seen by the arrangement of the component parts of the mammæ provision is made not merely for the secretion but for the retention of a large quantity of milk. In Fig. 5, which represents the udder of the cow stripped of the skin, its ressels injected, \&c., one of the anterior glands is laid open to show the large reservoir ; $a$ the end of a probe is depicted as being passed into it, having been carried upward through the teat, through the duct in the te: $; b, b$ represent the smaller reservoirs, some of which are opening into the large one, and $c, c$ show the lobulated condition of the external portion of the posterior glands, which is produced by collections of lactiferous ducts. The mammary veins are represented by $d, d$, and $e$ is the origin of the superficial abdominal vein, commonly cilled the milk vein.

In regard to the veins of the manmæ, as shown in Fig. $5(d, d$ and $e)$, they are very numerous and large, it being necessary that every facility should be given for the re- 


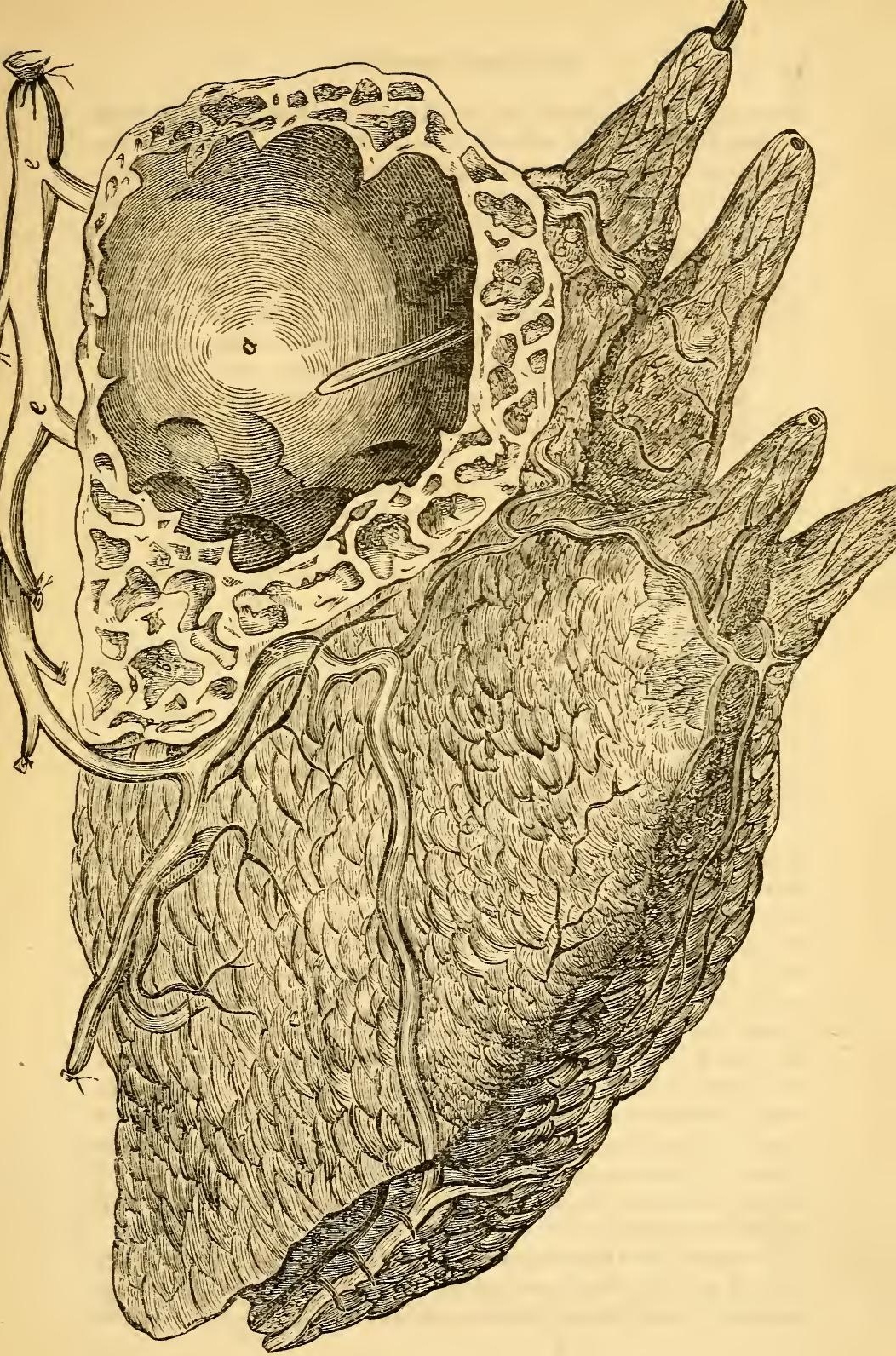

Fif. :-... View of the ndider of the cow after being stripped of the skin which covers it.-Sin A. COOPEl. 
turn into the system of the blood which has not been appropriated for the secretion of milk, or for the maintainance of the integrity of the glands.

Taking their rise chiefly from the capillary network of the milk follicles the small vesticles coalesce to form disdinct branches of veins-the mammary veins. Many of these pursue a course toward the upper and front part of it for the purpose of carrying the blood into the large vessels which are met with in both these situations. The veins which pass backward empty themselves into the inguinal and these in turn into the iliac veins, by which this portion of the blood is returned to the heart through the posterior vena cava. Those, on the contrary, which proceed forward convey the blood into large vessels-the superficial abdominal veins, commonly known as the milk veins, and by them it is transmitted into the internal pectoral veins, reaching the heart by means of the anterior vena cava.

The size of the superficial abdominal vein (see $e$, Fig. 5) on either side of the belly, sufficiently indicates that the greater part of the blood coming from the udder passes through them. The size of these veins, as is well known, has always been taken as an indication to some extent of the capacity of the cow for yielding milk. A large flow of milk would necessarily require a large amount of blood to be distributed throngh the mammx, and as this blood must be carried back to the heart, the milk veins must necessarily be larger or smaller in proportion to the amount of blood used in these parts. The four glands forming the udder, it may be observed, are as separate and distinct from each other as if they had been placed at considerable distance apart. This perfect and complete isolation of the mammæ is a wise provision of nature; for should one, two, or even three become affected with disease and lose the power of secreting milk, the remaining gland or glands would still furnish a sufficiency of the fluid to maintain at least the vitality of the offspring. The separation of the one gland from the other is effected by a reflection of fibrous tissue coming off from the walls of the abdomen and dipping as a septum between them. The same tissue, also, is continued as a covering to each gland, and thus binds the whole of them together. This arrangement places the entire udder in a kind of sling, 
and maintains its elose connection with the abdominal parietes.

In many aged cows the external reflection of fibrous tissue, from having been kept long on the stretch, loses some of its suspending power, and hence in such animals the udder is often very loose and pendulous, occasionally hanging, in consequence, to within a few inches of the ground-a state of things which is irremediable.

\section{MODE OF ACTION OF THE MAMMARY GLAND.}

A question of some interest in connection with the function of the mammary gland, is whether it fabricates in itself by the agency of cells the proximate constituents of milk, or whether it merely strains them from the blood in which they pre-exist. Authorities differ in regard to this question. DraPER, the well-known physiologist, says: "The influence of special structure is disproved by the numerous, well-authenticated cases now on record, in which portions of the skin, or the stomach, the navel, intestines, the axilla and glands in the groin have assumed a vicarious action and secreted milk." He infers, therefore, that the proximate constituents of the milk are not manufactured by reason of any special structure of the gland which secretes them, since other structures can assume a vicarious action.

Of the proximate elements of milk, many, such as the entire group of its salts, are acknowledged on all hands to pre-exist in the blood; and these comstituents, about 1-25th of its solid ingredients, must be admitted to pass into the secretion by straining only. Ot the other solid ingredients the fat, which constitutes about one-fourth, also exists in the blood, being derived by lacteal absorption from the food. There are many facts which show that the identical fat occirring in the food is actually delivered by the mammary gland with many of its qualities unchanged. Thus, if by chance cows should eat the tender shoots of pine trees or wild onions or other strong-smelling herbs, the milk is at once contaminated with the special flavor of these oils. The feeding of turnips also produces the same effect. If half the allowance of hay for a cow is replaced by an equivalent of linseed cake rich in oil, the cow maintains herself in good condition, but the 
milk produces a butter more than usually soft, and tainted with a peculiar flavor derived from the linseed oil.

Again he says, that fats of various kinds must always exist in the blood. A simple arithmetical computation, founded on the data furnished by the tables, of the constitution of blood and of milk, will show that there is at any moment a sufficient supply of fatty matters in the blood to furnish two-thirds of the diurnal amount of milk. It does not therefore, seem philosophical, nuder these circumstances, to impute to the mammary gland the power of forming butter. It doubtléss obtains that substance directly from the blood, and it may be, he observes, that those bodies which are conceived of as cells, and which are supposed to arise in the lobules of the gland in successive broods, which run a rapid career, coming into existence, reaching maturity, dying and deliquescing with incredible rapidity, are in reality nothing more than oil globules, which have coater themselves over with a cyst of coagulated caseine, as in Ascheron's experiments, or just as they become coated with a similar film, immediately on passing from the intestine into the lacteal vessels; and this, accordingly, is the opinion which Draper entertains.

Again, he says there has been much controversy among chemists respecting the existence of caseine as a normal ingredient in the blood. Theoretically there does not appear any solid reason for denying that it may be one of those constituents, considering the analogy of constitution which it shows with albumen. From the acknowledged fact that the acid, interstitial juice of muscle-fiber contains caseine, there cannot be any doubt that that substance must pre-exist in the blood. Chemically, the transition from albumen to caseine is not to be regarded either as an ascending or declining metamorphosis, but only as the temporary assumption of a state of passage onward to the condition of fibrine.

The question is argued by Druperat considerable length, and he concludes from the data at hand respecting the origin of the different constituents of the milk, the caseine, the butter, the sugar and the salts, that he may come to a definite conclusion regardiug the physiological action of the mammary gland. And as it appears that all the constituents which its secretion contains are found in the 
blood, we can scarcely suppose that the gland itself does more than merely strain them out. But of course, in common with all such structures, it possesses what might be aptly termed an elective filtrating power; thus it permits the exudation of some substances from the blood, but refuses a passage to others.

Dr. Sturteraxt, in a recent lecture before the Connecticut State Board of Agriculture, seems to have taken the same views as those expressed by Draper-at least so far as relates to the formation of the butter globules. He says:-"The minute secreting cells of the udder are really but a stage of development of the butter globule itself. The cells grow by budding and the new cell is cast off and becomes a butter globule. What was before a part of the animal is now a globule. In the early stages of lactation and before parturition, the process of casting off milk cells is not so complete as later.

"The milk globules are found to be larger in the Jersey cow than in the Ayrshire, and larger in the Ayrshire than in the American Holstein. The membrane which covers them and which has to be ruptured in churning, is more easily broken in the Jersey than in the Ayrshire, and thus butter is formed quicker. The contents of the globules vary in character-in some kinds waxy, in others not. That of the large globules makes the best butter. As to the variation consequent on time, the functional activity of the udder decreases with time after calving, and finally its action ceases. The globule is larger too, at the time of calving, and butter is then brought more easily by churning. Per contra, the autumn cheese is richer than the early cheese, the globules being smaller and more of them escaping butter making and getting into the cheese.

"These two points of variation by breed and time from calving, are important points for the dairyman to consider and act upon. The influence of food upon the milk globules must be either to increase the size of the globules, or by increasing the energy of the glands produce greater rapidity of production."

Other physiologists take the ground that the sugar of milk, caseine and true butyrine have a doubtful existence in, or have not been clearly recognized in the blood, and hence that these constituents are formed in the mammary gland. Lehmans says, we cannot assume, as Chevreul 
and other chemists (and even he himself) formerly did, that the constituents of nilk exist performed in the blood; and finally, after reviewing the arguments that are given which favor the view that there occurs a preliminary remodeling of the substances to be conveyed by the blood to the glands for secretion, he is inclined to recognize the principle that the main constituents of all true secretions, like those of the liver and mammary glands, are first formed within the glandular organs themselves.

\section{MILK BEST FROM YOUNG ANIMALS.}

Variations in the composition of milk are observed to depend upon age and bodily health. Young cows yield a milk more rich in solids than old cows. This point seems to be well understood by dairymen in England, many of whom make it a rule to turn their cows off when they have arrived at from seven to eight years of age. On this side of the Atlantic, the difference in the quality of milk on account of age, has received scarcely any attention from dairymen, the general view taken being that an old cow's milk is as good, if not better, than the milk of young cows.

I have now given the generally accepted views of distinguished physiologists in regard to the structure of the udder and the functions of the glands in the secretion of milk, and we now pass to what, in a commercial aspect, may be considered the chief constituent of milk, namely-

\section{THE FATTY MATTER OF MILK.}

While the proportion of caseine is tolerably constant, varying but little, the amount of butter or fatty matter in milk is subject to great variation. From an extensive series of analyses made by Dr. Voelck ER, the distinguished chemist of the Royal Agricultural Society of England, he gives the following as the greatest variation in genuine cow's milk; that is to say, in healthy milk, or milk not produced in any way abnormally:

COMPOSITION OF NEW MILK.

\begin{tabular}{|c|c|c|c|c|}
\hline \multirow{6}{*}{ 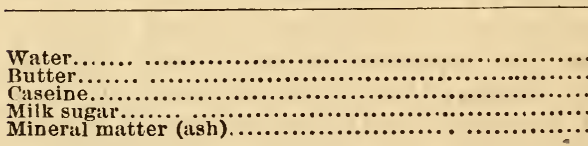 } & 1. & 2. & 3. & 4. \\
\hline & 83.90 & 85.20 & 87.40 & 89.95 \\
\hline & 7.62 & $4.96 \mathrm{j}$ & 3.43 & 1.98 \\
\hline & & & & 2.94 \\
\hline & 4.46 & 5.05 & 5.12 & 4.48 \\
\hline & .71 & 1.13 & & \\
\hline & 100.00 & 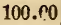 & $100 . c 0$ & 100.00 \\
\hline Percentage of dry matters..................... & 16.10 & 14.80 & 12.60 & $10.0 \dot{i}$ \\
\hline
\end{tabular}


The same author gives the following table, as showing the great difference in the composition of the milk of different animals :

\begin{tabular}{|c|c|c|c|c|c|c|c|}
\hline \multirow{5}{*}{ 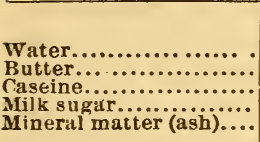 } & Cow. & Human. & Ass. & Goat. & Ewe. & Dog. & Dog. \\
\hline & 87.02 & 88.94 & 91.65 & 85.54 & 76.30 & 83.10 & 67.20 \\
\hline & 3.13 & 2.67 & .11 & 4.08 & 1.20 & 4.4 & 13.30 \\
\hline & 4.87 & 3.92 & 1.82 & 4.52 & 13.37 & 5. 76 & 14.60 \\
\hline & $\begin{array}{l}4.76 \\
.60\end{array}$ & $\begin{array}{l}4.35 \\
.14\end{array}$ & $\begin{array}{l}E .05 \\
.34\end{array}$ & 5.86 & $\begin{array}{l}7.10 \\
1.63\end{array}$ & 5.73 & 3.42 \\
\hline & 100,00 & 100.00 & 100.00 & 100.00 & 100.00 & 100.00 & 1.00 \\
\hline
\end{tabular}

No. 3, in the first table, represents the composition of milk of average good quality.

Generally speaking, milk is richer in the fall and poorer in the spring. The quality of cow's milk is not only affected by the age of the animal, but by the distance from the time of calving. Climate also affects the quality of milk in a remarkable degree. In moist and temperate seasons we obtain a larger quantity, though generally a poorer quality of milk than in dry, warm seasons. The race and breed and size of animals have also an important influence on the quality of milk.

According to VOELCKER, good milk of average quality contains from $10 \frac{1}{2}$ to 11 per cent. of dry matter and about $2 \frac{1}{2}$ per cent. of pure fat. It yields from 9 to 10 per cent. of cream. Milk which contains more than 90 per cent. of water and less than two per cent. of pure fat, is naturally very poor or has been adulterated.

When milk contains from 12 to $12 \frac{1}{2}$ per cent. of solid matters and from 3 to $3 \frac{1}{2}$ per cent. of pure fatty substances, it is considered rich. And if it contains more than $12 \frac{1}{2}$ per cent. of dry matter and 4 per cent. or more of pure fat, it is of extra rich quality. Such milk throws up from 11 to 12 per cent. of cream in bulk on standing for 24 hours at 62 degrees Fahr.

\section{COMPOSITION OF CREAM.}

Cream varies in composition according to the circumstances under which it is produced, and as a consequence of these differences in the composition of cream variable quantities of butter are produced from a given bulk of cream. The value of milk, then, for butter-making cannot be determined simply from the percentage of cream thrown up. The butter value must be obtained by churning the cream. 
Voelcker analyzed four different samples of cream, which gave the following results:

\begin{tabular}{|c|c|c|c|c|}
\hline & 1. & 2. & 3. & 4. \\
\hline 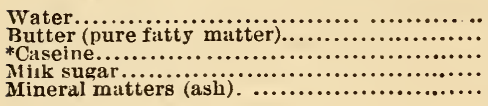 & $\begin{array}{r}74.46 \\
18.18 \\
2.69 \\
4.08 \\
0.59\end{array}$ & $\begin{array}{r}64.80 \\
25.40 \\
7.61\} \\
2.19\end{array}$ & $\begin{array}{r}56.50 \\
31.57 \\
8.44 \\
3.49\end{array}$ & $\begin{array}{r}61.67 \\
3.43 \\
2.62 \\
1.56 \\
0.72\end{array}$ \\
\hline${ }^{*}$ Containing nitrogen $\ldots \ldots \ldots \ldots \ldots \ldots \ldots \ldots \ldots$ & $\begin{array}{r}100.00 \\
.43\end{array}$ & 100.00 & 100.00 & $\begin{array}{r}100.00 \\
.42\end{array}$ \\
\hline
\end{tabular}

Dr. Sturtevant gives the following authorities on the analyses of cream:

\begin{tabular}{|c|c|c|c|c|c|c|c|}
\hline & Water. & Solids. & Butter. & Caseine. & Sugar. & Ash. & Etc. \\
\hline 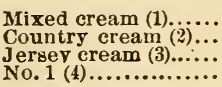 & $\begin{array}{l}5925 \\
49.00 \\
36.40 \\
74.46\end{array}$ & $\begin{array}{l}40.75 \\
51.00 \\
63.60 \\
25.5 !\end{array}$ & $\begin{array}{l}35.00 \\
42.00 \\
56.80 \\
18.18\end{array}$ & $\begin{array}{l}2.20 \\
4.20 \\
3.80 \\
2.69\end{array}$ & $\begin{array}{l}3.05 \\
3.80 \\
2.80 \\
4.08\end{array}$ & $\begin{array}{l}.50 \\
.60 \\
.20 \\
.59\end{array}$ & \\
\hline 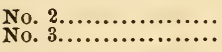 & $\begin{array}{l}64.80 \\
56.50\end{array}$ & $\begin{array}{l}35.20 \\
43.50\end{array}$ & $\begin{array}{l}25.40 \\
8157\end{array}$ & \multicolumn{2}{|c|}{$\begin{array}{l}7.61 \\
8.44\end{array}$} & $\begin{array}{l}2.19 \\
3.49\end{array}$ & \\
\hline $\begin{array}{l}\text { No. } 4 \ldots \ldots \ldots \ldots \ldots \ldots \\
\text { Cream }(5) \ldots \ldots \ldots \ldots \ldots\end{array}$ & $\begin{array}{l}61.67 \\
63.28\end{array}$ & $\begin{array}{l}38.33 \\
36.72\end{array}$ & $\begin{array}{l}33.43 \\
29.40\end{array}$ & $\begin{array}{l}2.62 \\
4.22\end{array}$ & $\begin{array}{l}1.56 \\
2.08\end{array}$ & $\begin{array}{l}\pi_{2}^{2} \\
.40\end{array}$ & .56 \\
\hline
\end{tabular}

(1) Prof. Mueler as quoted, Trans. Vt. Dairymen's Ass'n, 1872, p. 150.

(2 and 3) Dr. Percy-Trans. Med. Soc. State of N. Y., 1860, p. 47.

(4) Dr. Voeleker-Journal R. A. S., XX1V. p. 298.

(5) Dr. Hannenburg quoted-Ag. of 0.1858, p. 282.

And he says, "We find from these analyses that some creams may yield three times as much butter as other creams. In other words, that milk yielding 10 per cent. of cream may furnish more butter than another milk indicating 30 per cent. of cream," and he concludes further, "that there is not necessarily any connection between the cream percentages and the butter yield." The modest cow with a small percentage, may make more butter than the vaunted cow which is supposed to average 25 to 30 per cent. of cream."

European authorities all say that cream is slightly denser than pure water, and that consequently it sinks in distilled water. Voelcker found the specific gravity of cream at a temperature of 62 degrees Fahr. to range from 1,0194 to 1,0129 , the milk having been skimmed after standing fifteen to forty-eight hours, respectively.

Dr. Sturtevant, in a recent paper before the American Dairymen's Association, says, in his own experiment using cream from the top of a cream jar, he had obtained a specific gravity of 983 by weight, and, on the other hand, he has found cream that would sink in water. He gives also different authorities, in regard to the specific gravity 
of cream, thus Letherby finds it to be 1024,4 ; $\mathrm{Dr}$. HANNEBERG of Stockholm, 1004,9, and 1005,05. These differences may, perhaps, be explained, in part, at least, from the fact that the first portions of milk which rise, are always thin but rich in fat. During milking and the subsequent agitation to which milk is exposed, a portion of the milk globules get broken, in consequence of which their fatty contents, liberated from the denser caseineshells, rise to the surface with greater facility, and then occupy less room than the unbroken milk globules, which on account of their greater specific gravity, are more sluggish in rising.

Hence it must be observed that care must be taken that the cream be properly mingled together, before attempting to get the specific gravity. And when this is done, we shall, I think, generally find that cream is slightly denser than pure water, and this agrees with my own observations.

CREAM OF FIRST DRAWN MILK OF POORER QUALITY THAN LAST DRAWN.

Of the milk drawn from any cow at one time, that part which comes off first is always thinner, and of a much worse quality for making butter, than that obtained during the latter half of the milking.

From an analysis of specimens of milk, from eight different cows, as given in the London Lancet, the percentage of cream in the first drawn and second drawn milk, was as follows:

\begin{tabular}{|c|c|c|c|c|}
\hline \multicolumn{3}{|c|}{-FIRST-DRAWN MLLK- } & \multicolumn{2}{|c|}{-SECOND-DRAWN MILK- } \\
\hline Cows. & $\begin{array}{l}\text { Specific } \\
\text { gritvity. }\end{array}$ & Cream. & $\begin{array}{l}\text { Specific } \\
\text { gravity. }\end{array}$ & Cream. \\
\hline $\begin{array}{l}1 \ldots \ldots \\
2 \ldots \ldots \\
3 \ldots \ldots \\
4 \ldots \ldots \\
5 \ldots \ldots \\
6 \ldots \ldots \\
7 \ldots \ldots \\
8 \ldots . .\end{array}$ & $\begin{array}{l}10: 7 \\
1026 \\
1027 \\
1029 \\
1030 \\
1030 \\
1029 \\
1031\end{array}$ & $\begin{array}{c}9 \\
13 \\
8 \\
7 \\
11 \\
8 \\
31 / 2 \\
2\end{array}$ & $\begin{array}{l}1023 \\
1023 \\
1025 \\
1024 \\
1024 \\
1022 \\
1026 \\
1030\end{array}$ & $\begin{array}{l}25 \\
22 \\
10 \\
15 \\
32 \\
25 \\
71 / 3 \\
5\end{array}$ \\
\hline & & $611 / 2$ & & $1411 / 2$ \\
\hline
\end{tabular}

Thus, while the cream of the whole eight samples of the first drawn milk, amounted to $61 \frac{1}{2}$, that of the last drawn amounted to $141 \frac{1}{2}$, or more than double the quantity of cream. The specific gravity of the last drawn milk, it will be observed, is also lower than of that first drawn. 
When milk is set aside for cream, the portion of cream which first rises to the surface is richer in quality, and equal in quantity to that which rises in a second equal space of time, and the cream which rises in a second interval of time is greater in quantity and richer in quality, that which rises in a third equal space of time. That of the third is greater than that of the fourth, and so of the rest; the cream that rises continuing progressively to decrease in quantity and quality so long as any rises to the surface. The cream then rises in layers, each of which must make a different quality of butter. Thick milk throws up a much smaller proportion of the cream which it actually contains, than milk that is thinner, but the cream is of richer quality. Hence, if water be added to the thick milk it is found in practice to afford a considerably greater quantity of cream, and consequently more butter than it wonld have done if allowed to remain pure, but its quality at the same time is deteriorated.

Some of the fat globules of milk are so minute, that they do not rise to the surface in cream, the amount of fat remainiing being greater or less, according to the character of the milk.

VoELCKER analyzed two samples of skimmed milk, and found the butter left in it to be about $\frac{3}{4}$ of 1 per cent.

The following is the composition:

COMPOSITION OF SKIMMED MILK.

\begin{tabular}{|c|c|c|}
\hline & No. 1. & No. 2. \\
\hline 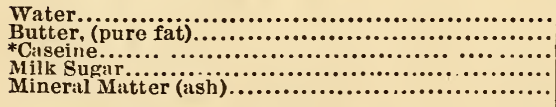 & $\begin{array}{r}89.65 \\
.79 \\
3.01 \\
5.72 \\
.83\end{array}$ & $\begin{array}{r}89.40 \\
.76 \\
2.94 \\
6.95 \\
.85\end{array}$ \\
\hline 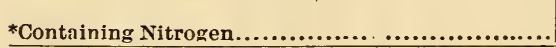 & $\begin{array}{r}100.00 \\
\quad .48 \\
\end{array}$ & $\begin{array}{r}100.00 \\
.47 \\
\end{array}$ \\
\hline
\end{tabular}

The following table presents a view of the composition of milk, cream, butter and American cheese.

\begin{tabular}{|c|c|c|c|c|}
\hline \multirow{3}{*}{ 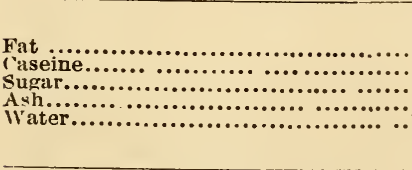 } & Milk. & Cream. & Butter. & Am,Cheese. \\
\hline & $\begin{array}{r}4.00 \\
3.25 \\
4.50 \\
87.75 \\
87.50\end{array}$ & $\begin{array}{r}35.0 .2 \\
2.20 \\
3.05 \\
.50 \\
59.25\end{array}$ & $\begin{array}{r}85.00 \\
.51 \\
.70 \\
.12 \\
13.67\end{array}$ & $\begin{array}{r}34.41 \\
25.87 \\
5.01 \\
5.90 \\
30.81\end{array}$ \\
\hline & 10000 & 100.00 & 100.00 & 102.00 \\
\hline
\end{tabular}

MORE BUTTER OBTAINED BY MIXING MILK OF DIFFERENT cows.

The question has been started recently in regard to the 
variation in the size of the fat globules in the milk of cows of different breeds, and it has been asserted that by mingling a large globuled milk with a small globuled milk a loss would result in butter making. The Practical Farmer, (Philadelphia), makes record of an experiment touching the question. It says the experimental farm, (Penn.) made an experiment to test the gain or loss from keeping the milk of each cow separate, or mixing, as is usually done. The experiment began January 13, and continued one week. The milk of each cow was accurately weighed, and one-half of it put in a common milk pan and skimmed in thirty-six hours. The other' half thoroughly mixed with half the milk from the other cows, and all treated alike as near as possible. The temperature of the milk room was kept at 58 degrees as near as possible. No soming used in the milk.

The cows were fed each morning with 10 pounds of corn fodder, 8 pounds of sugar beets, and $4 \frac{1}{2}$ qualts of corn meal and wheat bran, equal parts. At noon, with one-third sheaf of corn fodder; in the evening, with the same quantity of meal to each, 3 pounds of cut hay and 7 pounds of uncut hay, all fed dry. The temperature of the atmosphere was noted night and morning. Result of experiment as follows :

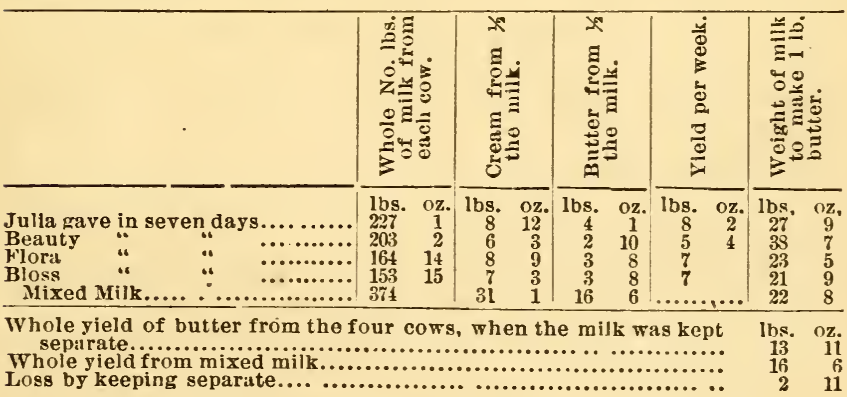

The cows came in fresh as follows:

Julia. December 11, 1874.

Beaut

Bloss. 15 ,

The cream from the separated lots took more churning to break and gather.

The superintendent added the following comments: 
Although the experiment did not have much practical bearing-for no dairyman would want to keep his milk separated in this way-yet it is a satisfaction to feel the most convenient way in this case is also the best.

I am sorry we cannot give any satisfactory explanation for the above results. We guess, however, that there are two reasons why the mixture of poor and rich milk contains more caseine, is heavier, and offers more resistance to the passage of the butter globules to the surface. The globules in the poor milk are also smaller, and from this c:ulse are thrown up with more difficulty. The addition of richer milk helps in both these respects.

Again, after the "breaking" of the butter, as it is called, the smaller globules in the poor milk "gather" with difficulty; but in the "mixed" milk, the larger globules aid in forming proper milk for the "gathering" process. At any rate the evident difficulty in gathering the butter from poor milk, indicates this as a plausible solution.

If these conclusions are correct, there would be an advantage in adding the milk of the Jersey cow to that from the common cow or other breeds, because the milk globules of the Jersey are considerably larger than those in the milk of other breeds.

UNIFORMITY IN THE COMPOSITION OF MILK.

Prof. S. W. Johnson of Yale College, in referring to the researches of Prof. Alexander Muller and others, in Sweden, says :

Analyses were made of the mixed milk of fifteen cows (five Ayrshire, five Pembrokeshire, and flve Swedish cows), which were highly fed and milked at $6 \frac{1}{2}-7 \frac{1}{2} \mathrm{~A}$. M., and $4 \frac{1}{2}-6 \frac{1}{2}$ o'clock, $\vec{P}$. M. These extending throughout a whole year, gave the following average result:-

One hundred parts of milk gave

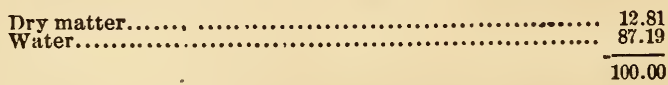

The above dry matter consisted of

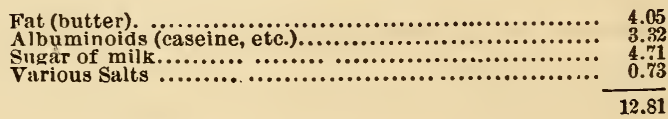


The fluctuations during the entire period were remarkably small. The lowest percentage of water observed was 85.92, and the highest 88.35. In but four instances did the water fall below 86.6, and in but four did it rise above 88. The composition of the milk of uniformly well-fed cows is therefore very uniform, and scarcely varies throughout the year whatever may be the change in temperature, weather, \&c.

Morning and evening milk exhibit a constant, though slight difference in composition, which consists simply in containing half of one per cent. more fat at night than in the morning. In the morning milk this fat is replaced by almost precisely the same quantity of water.

THE LESS SPACE OF TIME INTERVENING BETWEEN MILK-

ING THE MORE FAT.

Further investigation showed that the proportion of fat is less in proportion as the time is longer between the milkings. Thus, milk taken after an interval of

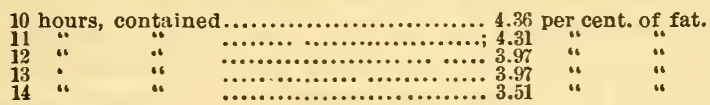

Taking into account the greater quantity of milk obtained in the morning, the actual amount of fat yielded by the cow is rather more at morning than at night.

\section{PERCENTAGR OF CREAM AND BUTTER IN MILK.}

In making butter, 100 parts of milk yield, on the average, in round numbers, the following proportions of cream, butter, etc., provided the cream rises in a cool apartment, so that no sensible evaporation of water takes place:

Skimmed milk.................................................... ${ }_{90}^{10}$

$\overline{100}$ milk.

The ten parts of cream consist of

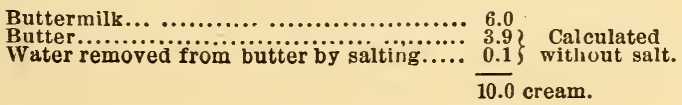


The average percentage composition of these products is given in the subjoined table:

\begin{tabular}{|c|c|c|c|c|c|c|}
\hline & $\begin{array}{l}\text { New } \\
\text { milk. }\end{array}$ & $\begin{array}{c}\text { Skinumed } \\
\text { milk. }\end{array}$ & Cream. & $\begin{array}{c}\text { Butter- } \\
\text { milk. }\end{array}$ & Buttert & Brine $\neq$ \\
\hline 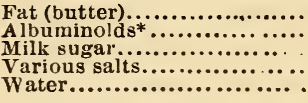 & $\begin{array}{r}4.00 \\
3.25 \\
4.50 \\
0.75 \\
87.50\end{array}$ & $\begin{array}{r}0.55 \\
3.37 \\
4.63 \\
0.78 \\
90.64\end{array}$ & $\begin{array}{r}35.00 \\
2.20 \\
3.05 \\
0.50 \\
59.25\end{array}$ & $\begin{array}{r}1.67 \\
3.43 \\
4.61 \\
0.77 \\
89.62\end{array}$ & $\begin{array}{r}85.00 \\
0.51 \\
0.70 \\
0.12 \\
13.67\end{array}$ & $\begin{array}{r}0.00 \\
0.39 \\
3.84 \\
0.86 \\
94.91\end{array}$ \\
\hline Totel... & 100.00 & 100.00 & 100.0 & 100.00 & 100.00 & 100.00 \\
\hline
\end{tabular}

* Caseine and albumen.

+ Unsalted.

\# Brine that separates on working after salting, salt not included.

Butter is produced by the coalescence of the small particles of oil which are suspended in milk, and partially separated in the cream. Chemically considered, it is a mixture of oleine and.palmitin, with a trace of phosphate and other salts, and certain odoriferous fats or oils, from which it derives its flavor,

\section{THEORY OF SOURING.}

He remarks further, that stirring of the cream-as for instance, in the cream pot-does not promote souring but rather hinders it, by increasing access of air. The circumstances that influence the rapidity of souring are chiefly temperature and access of air. When milk sours it is because of the formation of lactic acid from the milk sugar. This chemical change is the result of the growth of a microscopic vegetable organism which, according to HaLlier's last investigations, is of the same origin as common yeast. Like common yeast, this plant requires oxygen for its development. This it gathers from the air, if the latter have access; but in comparative absence of air-as when growing in milk-it decomposes, the latter (its sugar) and the lactic acid is a chief result of this metamorphosis.

If milk which, by exposure to the air, has had the microscopic germs of the ferment plant sown in it be then excluded from the air as much as possible, the ferment in its growth is necessitated to decompose the milk sugar, and hence the milk rapidly sours. On the other hand, exposure to the air supplies the ferment partially with free oxygen and the milk remains sweet for a longer period. Such is the theory of the change. And this is in accordance with the experience of dairymen, and explains why milk is often found loppered at the bottom of 
a pan, while at the top there is no appearance of coagulation.

\section{BUTTER.}

We may now pass on to the consideration of butter and note some of the characteristic differences which this substance has in its relation with other animal fats.

If we consider how extensively butter is consumed; how highly it is relished by all classes in the civilized world; how nearly it meets the taste of mankiud, even from childhood onward to old age-we might naturally infer that there is something in the constitution of butter which particularly adapts it as an important element of our food; that it is, so to speak, more highly organized, more delicately flavored, and thus in better form to meet the requirements of digestion and assimilation than any other fat which has been separated from the relative condition it originally occupied in the animal economy.

By churning, as is well known, the caseine shells are broken and the contents of the milk globules are made into butter. Butter, according to VoELCKER, consist mainly of a mixture of several fats, amongst which palmit in, a solid,crystillizable substance is the most important. Palmitin, with a little stearine, constitutes about 68 per cent. of pure butter. Mixed with these solid fats are about 30 per cent. of oleine (a liquid, fatty matter) and about two per cent. of odoriferous oils. The peculiar flavor and odor of buttcr are owing to the presence of this small proportion of these peculiar oils, namely-butyrine, caproine and capryline.

In butter as it comes to the table we find, besides these fatty matters, about 16 to 18 per cent. of water, one to two per cent. of salt and small, variable quantities of caseine shells. The more perfectly butter is washed and freed of its buttermilk, the better the butter keeps; for caseine, on exposure to air in a moist state (especially in warm weather) becomes rapidly changed into a ferment, which, acting on the volatile, fatty matters of butter, resolves them into glycerine and butyric acid, caproic acid and caprylic acid.

The occurrence of these volatile, uncombined, fatty acids in rancid butter, not only spoils the flavor, but renders it more or less unwholesome. 


\section{COMPOSITION OF BUTTER.}

Cows' butter, according to Browers, has the following composition :

Margarat $\epsilon$ of glycerine [Margarine]

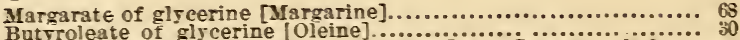

Butyrate [Butyrine]. Caproste. [Caproine] ind Caprate of glyce-

rine. [Caprine]..............................................

Butter.

100

The same anthority gires the following as the formula for the fatty acids of butter:

COMPOSITION OF THE FATTY ACIDS OF BLTTER.

Margaric acid............................................ H4, H33. O3.

Butyrolic acid.................................................... H

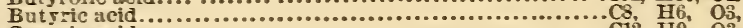

Caproic acid....................................... H9, O3.

Capric acid........................................ His, Hit, Os.

The marrow of large hones, says Berzelics, is absolutely of the same nature as the other fat of the same animal. The difference of flaror which exists between the marrow of boiled bones and ordinary melted fat depends on foreign matters derived from the liquids in the cellular tissue by which the fat is surrounded, and especially by the extractiform substance, which is insoluble in alcohol.

\section{COMPOSITION OF LIQUID FAT IT MARROW.}

The proportion of liquid fats contained in marrow, according to Bracorrot, is as follows:

Beef-marrow

SOID EAT. (Stearine.)

Mution-marrow 76

LIQTIN FAT. (oleine.)

Mntton fat, as is well known, is softer than fat from beef, and the larger proportion of oleine in its composition readily explains the reason.

By subjecting animal fats to pressure, Bracoxyot procured the following proportions of stearine and oleine from the fats named below:

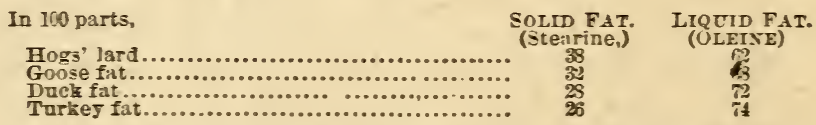

Hogs' lard contains, besides stearine and oleine, some margarine. Mutton suet consists of stearine, margarine, oleine, hircine and hircic acids. Like butter, the peculiar flavor of their fats is due to the volatile oils. Butter 
varies in its proportion of margarine and oleine according to the nature of the food and the period of the year.

It will be noticed that stearine is a leading constituent in the animal fats which have been named. This ingredient is in rery small proportion in butter; the palmitine, or, according to some authors, margarine, taking its place. Thus, in beef's marrow we have 76 per cent. of stearine, and in butter 68 per cent. of palmitine, with a little stearine. The oleine in butter is 30 per cent.; in beef fat, 24 per cent. The same remarkable difference will be noticed in the other fats when compared with butter.

In the so-called "oleomargarine," or beef suet butter, the stearine is expelled under great pressure, while, in order to get flaror from the volatile oils, the "oleomargarine" is mingled with milk or buttermilk and churned in the ordinary way.

I hare referred to the proportion of water and other substances not fat found in ordinary butter and which are not expelled in the process of washing and working out the buttermilk. These ingredients, the water, the cheese or caseine, and the sugar of milk, altogether amount to from 10 to 16 per cent. in ordinary butter. It is very difficult to get rid of all the cheesy matter, as it is now in an insoluble state; but it may be remored to a rery great extent by washing the butter in repeated potions of water or in saturated brine, thus decanting off the particles of caseine. In the best kinds of butter the cheesy matter rarely amounts to more than one per cent. In the inferior varieties it not unfrequently averages from six to seven per cent.

\section{EXPLATATIOF OF RAYCIDITY IY BCTTER.}

Now, as a general rule, we know that the more caseine that is left in butter the more apt it is to become rancid. "To render this intelligible," sars a writer in Morton's Cyclopedia, "attention must be given to the normal ingredients of pure butter. Margarine and oleine consists of margaric and oleic acids united to an organic base called oxide of lipyle. Margaric acid consists of 34 equiralents of carbon; 33 equivalents of hydrogen, and 3 equivalents of oxrgen, while oleic acid is constituted of 36 equivalents of carbon; 33 equivalents of hydrogen, and 3 equivalents of oxygen." 
It is known that the latter acid absorbs oxygen from the air with great avidity, producing peculiar compounds, among which, however, margaric acid has not been recognized; still the abstraction of two equivalents of carbon, in the form of carbonic acid, would be sufficient for its conversion, and this formation is so simple and common an occurrence in the organism of animals that oleic acid may be transferred into margaric acid during the formation of milk, thus producing more of the solid fat at one time than at another, and causing the variations in the firmness of the latter made from it. It is, however, quite gratuitous to suppose, with some anthors, that this transformation takes place during the process of churning.

When oleic acid absorbs oxygen from the air it acquires a very rancid smell, which is one of the causes of rancidity in butter. But the main cause is the production of butyric, capric, caproic and caprylic acids. These acids are probably not present in any quantity in perfectly fresh butter, but they are quickly formed by the cheese left in it acting on the sugar of milk.

Butyric acid has an odor of human excrement; caproic acid of sweat; capric acid has a rank smell, resembling a goat, while caprylic acid is the only one which is not obnoxious to the senses. These acids are volatile and soluble in water, and as rancidity of butter depends in a great degree upon their being present in appreciable quantity, a knowledge of this fact may be employed in depriving butter of its rancidity.

\section{HOW RANCID BUTTER MAT BE PURIFIED.}

For this purpose it should be melted in twice its weight of boiling water and well shaken with it. By this means the acids are dissolved and partly volatilized, the rancidity being thus removed. At all times butter may be purified by repeated melting, with fresh portions of water, the pure oil rising to the surface, leaving the impurities in the water. The butter loses its consistence by this operation, but that may be restored to it, at least to a great extent, by pouring it, when melted, into a large quantity of icecold water.

A process for purifying rancid butter was invented a few years ago, which consisted in cutting the butter into small lumps and spreading them out in a large vat. Then 
hot water is thrown down in a shower from a considerable distance upon the mass. The melted butter rises to the surface and the impurities are drawn off with the water. Then the butter is subjected to a shower of cold water, and in this way, by repeated washings, according to the rancidity of the butter, it is freed from the objectionable taste arid odor, and finally it is again worked and salted.

As the formation of the badly-smelling volatile acids depends upon the presence of caseine, this mode of purification removes the injurious ingredient. It must be remarked, however, that the butter becomes less pleasant to the taste, the water having taken up the small quantity of foreign substances which give to firesh butter its fragrance and agreeable taste. Some of the compounds of caprylic acid have a fragrant odor like that of the pineapple, but the smell of capryline itself is little known.

PROF. CALDWELL'S VIEWS ON THE COMPOSITION OF BUTTER.

Prof. Caldwell, in an address at Utica, N. Y., says : Cow butter, in the pure state, is a yellowish, slightly acid firt, which melts at about 70 degrees Fahr. It is composed, for the main part, of the three glycerides-oleine, palmatine and stearine-but further than that its composition is more complicated than that of any other animal fat; and in fact the exact composition of the small residue that remains after taking out the three glycerides named seems to be hardly settled. According to most authorities it is a mixture of butyrine, caproine and caprine, and further, Chevreul, who is one of the best authorities on the subject of the composition of fits, maintains that there is in the butter a peculiar combination between a part of the butyrine and the stearine, furming what he calls butyroleine.

\section{SUPPOSED COMPOSITION OF MARGARINE.}

On the other hand HaItz, who has worked up the composition of the fats almost as extensively as CHevreuL, and who was the first to maintain that the so-called margarine is only a mixture of stearine and palmitine, has found in butter still two other substances-butyrine and myrstrine.

VACCINIC ACID.

Another chemist has found in certain instances, in the 
place of butyric and caproic acids, the acids of butyrine and caproine, another acid which he called vaccinic acid.

\section{CAUSE OF RANCIDITY.}

The rancidity of butter is due, as in the case of the rancidity of other fats, to the decomposition of the glycerides, setting the acid of the glyceride free; in butter it is the butyrine and perhaps the odoriferons glycerides which suffer this change most readily.

THE GLYCERIDES.

Again he says:- "From what I have given as the results of the examination of butter by various chemists, it would appear that it is distinguished from all the other animal fats by the great number of glycerides of which it is composed. The complete separation of these glycerides from one another is about impossible, so that we can form at the most only an approximate estimate of their relative proportions in the various fats.

Voelcker estimates that palmatine, together with a little stearine, makes up 68 per cent. of the fats of butter, 30 per cent. is oleine and two per cent. is composed of the odoriferous fats, butyrine and its companions.

MORE OLEINE IN SUMMER BUTTER.

As every one knows, the proportion of liquid and solid fat varies, according to the season. Boussivgault found that summer butter contained about 60 per cent. of oleine, while winter butter contained only about 35 per cent.

The oils and fats are composed essentially and mainly of the three glycerides-oleine, palmatine and stearine; or of four-if there is such a glyceride as margarineand when all these are taken out there is a small residue remaining, concerning the composition of which we are yet to some extent uncertain and to which the characteristic flavor and odor of each fat is dne. The oils and fats contain when first extracted, several impurities, such as albuminous matters, coloring matters, mucus, \&c.

ARTIFICIAL BUTTER.

I have now presented the more recent views of scientists in regard to the fat found in milk, as compared with other animal fats, and a brief allusion may be made to the question of converting these latter into a form which may resemble butter so as to be substituted for it. 
We have our oleomargarine factories, in which oleomargarine, or artificial butter, is manufactured in large quantities: but as the product is deroid of that peculiar aroma and delicate flavor which belongs to genuine butter, I doubt whether it ever can be made a complete and successful substitute. In other words, genuine dairy butter of fine quality must always be in demand and find a ready sale. Prof. Caldwell says: "To any one who understands the true nature of the fats, the prejudice against oleomargarine butter, or a cheese containing fat from the caul of an ox, instead of the bag of the cow, because it is supposed not to be so clean and wholesome, appears somewhat nonsensical."

Oleo-margarine however, should go into the market under its own name, and if it is to obtain favor, it should be on its own merits and not under the name of genuine butter.

\section{FARII DAIRIES.}

The great bulk of poor butter comes from the farm dairies. The causes are various; the most important of which are lack of cleanliness, the want of proper dairy utensils, the seed of a good dairy room, or place for setting the milk, neglect in manipulating the cream at the right time, unskilful working, packing and storing the butter, and finally lack of knowledge in a part or the whole of the process required for making a prime article. Farm dairies have this advantage over the creameries, there is no hauling of the milk required and its condition can be watched and kept under the immediate control of the manufacturer from the time it is drawn from the cow until the butter is obtained. With this advantage we might naturally expect, with all needful appliances, and skill in manufacturing, the best butter could be made at the farm dairies. And such indeed, is 
often the fact, and when poor butter is the rule we must look for the cause in some defect connected with the dairy and its management.

We have alluded to a number of the leading requisites for the production of good milk, the importance of cleanliness in the stable and in the drawing of the milk from the udder, and a word may now be added in regard to dairying utensils.

\section{PAILS.}

Wooden pails are largely in use, and they are a nuisance in a well regulated dairy on account of the dif-

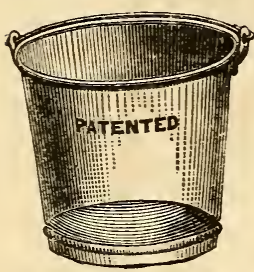

FTG. 6. ficulty of keeping them sweet and clean. Milk pails should always be of tin, and in cleansing dairy utensils after thorough washing, boiling hot voater should be used or what is better, if it can be had, a jet of hot steam thrown into all the parts which have come in contact with milk, for in this way the germs of ferment are destroyed.

Fig. 6 illustiates a pail of the Iron Clad Company of New York City. These pails are made of iron and tiuned after they are put together. Very heavy material is used in them and they are substantial and strong.

\section{THE CREAII STRAINER.}

The cream strainer is often found useful in farm dairies. When milk is set in shallow pans in the old way, portions of the cream get thick and are

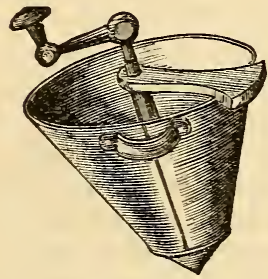

FIG. 7. mingled with hard dry particles, or "cream skins" and the butter in consequence is liable to contain "white caps" or be flecked. The cream strainer in such cases is of advantage, as it reduces the cream to a uniform consistency in all its parts, breaking down the skins and preparing the cream, so that in churning the butter will come evenly.

In Fig. 7 is an illustration of Baker's Excelsior Cream Strainer, the best we have seen for the purpose. 


\section{CHURNS.}

There is no implement of the dairy which has occupied the attention of inventors so much as the churn. 'The number of patents issued on this article may be well expressed under the name of legion, and yet it is the almost universal expression among the butter makers that nothing has been invented that will make any better butter than the old-fashioned dash churn. The objection to the dash churn is that it requires a considerable amount of power to keep it in motion, and various plans have been devised to lessen the labor of its operation when worked by hand.

In Fig. 8 is an illustration of a churn used for small quantities of cream, a gearing being attached by which the labor of working by hand is lessened.

In using the dash churn the dasher should fill about three-fourths of the section of the churn, as the cream will be subjected to a yielding pressure at each stroke, the butter globules being thus divested of the mem-

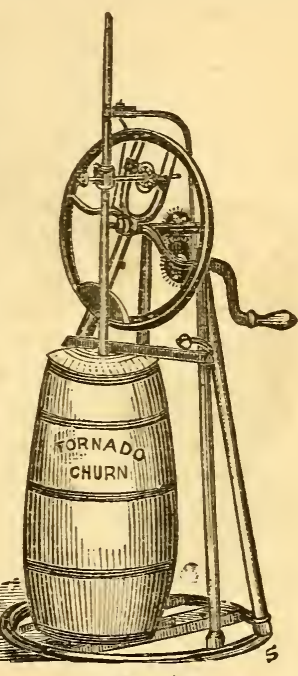

FIG. 8. brane that surrounds them, by pressure rather than by wearing or friction. Among the churns that have acquired notoriety for their excellence and which may be recommended in farm dairies not only on account of their making good butter, but for the ease with which they may be worked and kept clean, the most prominent perhaps is the Blarchard Churs, manufactured by P. Blanchard's Sons, Concord, N. H. It has been long before the public and is universally esteemed. It is arranged so as to work the butter free from buttermilk without change of dasher. The manufacturers furnish a pully for power, which can be applied to any sized churn, in the same place and manner as the crank.

Whipple's Rectangular Churs, manufactured by Corrish \& Curtis, Fort Atkinson, Wis., of which we give an illustration in Fig. 9, is of recent invention and 
well adapted to farm dairies. It is simply a cubical box, and hangs suspended on gudgeons from the two diagonal corners of the cube. As the box is revolved the cream constantly falls from corner to corner, thus giving a more diversified agitation than when in the box churn as ordi-

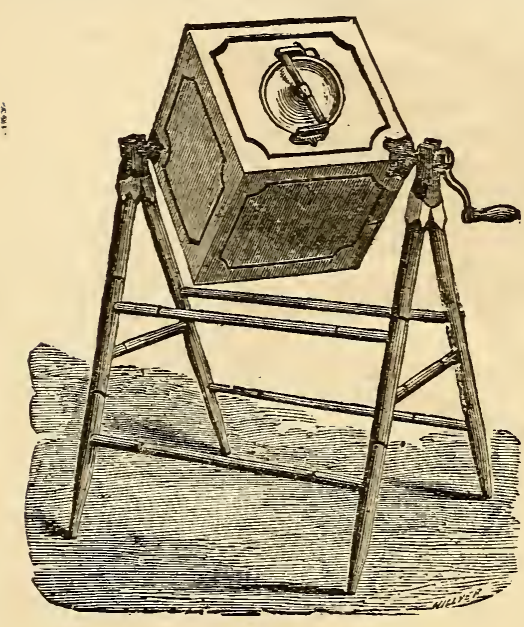

FIG. 9. narily arranged. It is more easily operated than the ordinary revolving box churn, and the butter forms in coarse grains, its operations in this respect being superior for a first-class product.

CHURN POWERS.

In small dairies a dog or sheep power is often found very serviceable for doing the churning. There are a number of different devices for the purpose, but one of the best is a machine constructed on the railway principle. It is very much liked by many, and is a cheap and efficient power. Where large quantities of cream are required to be churned, horse power will be employed and the most economical perhaps is the sweep, through the railway principle is often used.

\section{BUTTER WORKERS.}

Quite a number of butter workers have been introduced from time to time, some of them useful and others liable to injure the grain of the butter from their peculiar construction. The Eureka Butter Worker invented a few years since by J. P. Corbin of Whitney's Point, N. Y., will be found, on many accounts, convenient for farm dairies. The illustration, Fig. 10, shows its construction.

Rubber mops for cleansing floors of dairy rooms, together with soap, brushes, and "sal-soda," for keeping dairy utensils sweet und clean will be found exceedingly 
useful and I might say almost iudispensable for good dairy management.

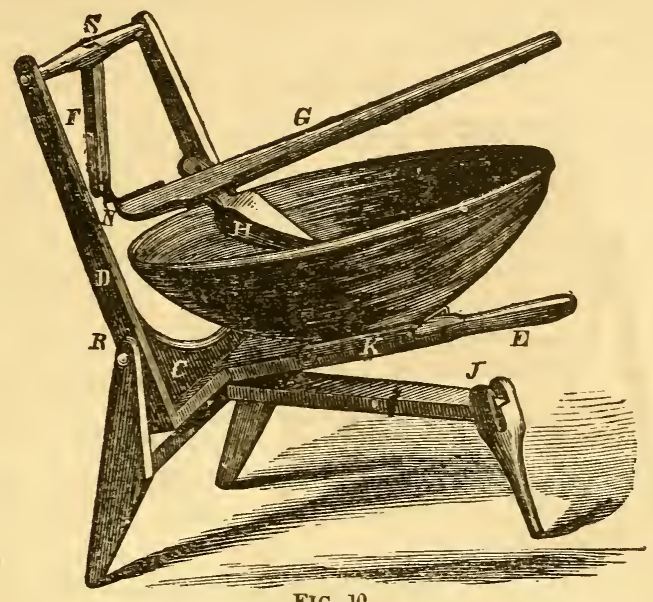

FIG. 10.

FARM DAIRY MILK-HOUSE.

Immense quantities of poor butter result from the milk being set in impropes places. The kitchen pantry, the living room and the cellar used to store vegetables and other family supplies, will impart peculiar taints to the milk and cream, in such a degree as to be destructive to flavor, even though the butter, in other respects be skilfully handled. Dairy rooms so situated as to catch the odor from the pig-sty, the cess-pool, or other decomposing filth, cannot be used for making good butter. There should be a freedom from filth and impurities of every description about the milk-house, and the milk should be delivered by the milkers in an ante-room or some point outside the milk room, and from thence conveyed to the place where it is to be set for cream, and in this way the fumes and the litter from the stable may be kept from the milk room. When milkers are allowed to come directly from the stable to the milk room it will be impossible to keep the latter place sweet and clean for the times being. There are hundreds of butter makers, we are aware, to whom the importance of this single point cannot be too strongly urged, since they often con- 
sider many little things of this kind, in regard to dairy management too insignificant to merit attention. But in butter making the observance of little things is often the great secret of success.

\section{Áration.}

Milk is undoubtedly improved by æration, the animal odors in this way passing off as the warm milk is exposed to the air. But it should be observed that when ceration is applied, the surrounding atmosphere should be sweet, and free from offensive odors. Milk ærated in an atmosphere loaded with the emanations of putrid mattervegetable or animal-would be likely to absorb odors, and hence caution should be taken that the æration be not made in the stable or other places where the air is tainted with disagreeable odors. There had been a number of devices for ærating milk, but perhaps the simplest and most easily applied, is Bussey's "Deodorising Strainer and Cooler."

It is simply a strainer pail, raised about two feet above the can and arranged so that the milk falls in a spray into the can.

FORCING AIR INTO THE MILK.

Jones \& Faulkner of Utica, N. Y., have brought

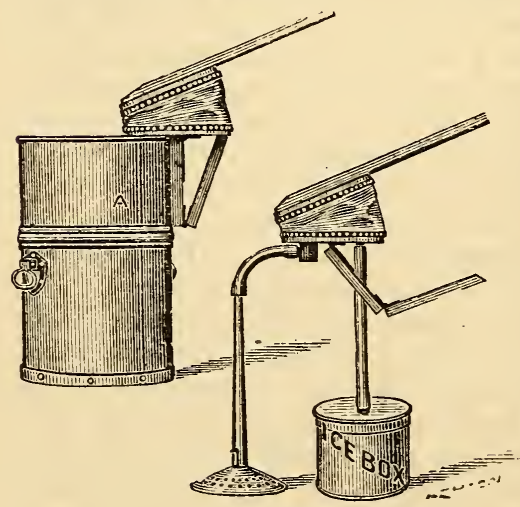

FIG. 11. out a handy device for ærating milk by forcing air into it. We give an illustration showing the manner in which this is effected in Fig. 11.

Either of the ærators here described, will be found exceedingly useful at farm dairies and they are of very great advantage in preparing milk at the farm in order that it may be delivered sound and

in good condition at the factory. 
CONTROLLING TEMPERATURE IN DAIRY ROOMS.

But, however woll we may have guarded all the conditions for getting milk in good order to the dairy room, there must be some means of controlling its temperature or the highest success cannot be obtained in butter making.

Among American butter makers the best temperature for holding the milk while the cream is rising is found to be from 56 degrees to 60 degrees, Fahr. The range of temperature should go no higher than 65 degrees. In a climate so variable as ours, it is evident some attention must be given to the construction of the milk room or the manner of setting the milk, in order to maintain a uniform temperature, as above named; otherwise, we shall be liable to have a constant change going on in the milk, the temperature rising or falling, often many degrees from day to day. The old method of setting milk in pans and in an ordinary room, has always been found objectionable during hot weather and to be the source of serious trouble and loss, simply on account of the difficulty of maintaining a suitable temperature. The employment of the house-cellar was perhaps the earliest improvement on the old plan of setting milk.

\section{THE SPRING HOUSE.}

The first introduction of the water system for controling the temperature of milk, dates a long away back in the spring house. These I have found existing in the older States, many of them built by the early settlers of the country, who often located their dwellings near a good, flowing spring, and not unfrequently erecting a substantial and elaborate stone or brick structure over the spring. In some of the older settled parts of Virginia the spring house is a distinguished feature. It is a wellbuilt structure, (nsually of stone,) immediately over or in close proximity to, a large spring of living water. The spring houses are for the most part well arranged, and some of them quite elaborate. The earth is excavated at the bottom and a wall built up on the inside, so as to form a vat between it and the outer wall or side of the building. Not unfrequently these vats are on two sides of the structure, or there may be a partition wall, so as to form two or three vats for the reception of water, and the arrangement is such that by closing the outlet in part, 
the water may be raised in the vats a foot or more, as desired. The floor of the spring house is usually of stone flagging, either cemented or laid in mortar so as to be dry and easily kept clean. Sometimes the entrance is on a level with the ground, and sometimes there is a flight of steps, according to the nature of the location.

The spring house is generally surrounded with trees which protect the structure from the sun's rays, thus serving to maintain a tolerably uniform and much lower temperature in the milk room during hot weather than that of the surrounding atmosphere. The milk is set in pans holding from eight to twelve quarts, the pans usually being deeper and not so broad as the old-fashioned pans, and they are provided with a bail so as to be more conveniently handled in lowering the milk to the water pool or raising it therefrom. With a good, cool spring, and a properly constructed spring house, fine butter can be produced.

PENNSYLVANIA SPRING HOUSE AND PHILADELPHIA

BUTTER.

The celebrated Philadelphia butter comes mainly from Chester, Lancaster and Delaware Counties, Pennsylvania. The milk is set on the same principle as that above desscribed, but the dairy structures are neater and more carefully built.

The spring-house is about 18 feet by 24 feet, built of stone, with its foundation set deeply in the hill-side, the floor being about four feet below the level of the ground at the down hill-side. The floor is of oak, laid on sand or gravel; this is flowed with spring water to the depth of three inches, and at this hight the flowing water passes out into a tank at the lower side of the spring-house. The milk, when drawn from the cow, is strained into deep pans which are set in the water upon the oaken floor. Raised platforms or walks are provided in the room for convenience in handling the milk. The walls of the springhouse are about ten feet high, and at the top on each side are windows covered with wire-cloth for ventilation. The depth of the milk in the pans is about three inches, and the flowing water which surrounds the pans maintains a temperature of about 58 degrees Fahrenheit.

The milk is skimmed after standing 24 hours, and the 
cream is put into deep vessels having a capacity of about 12 gallons. It is kept at a temperature of 58 degrees to 59 degrees, until it acquires a slightly acid taste, when it goes to the churn. The churn is a barrel revolving on a journal in each head, and diven by horse-power. 'The churning occupies about an hour, and after the buttermilk is drawn off cold water is added and a few turns given the churn, and the water then drawn off. This is repeated until the water as it is drawn off is nearly free from milkiness. The butter is worked with butter-workers, a dampened cloth meanwhile being pressed upon it to absorb the moisture and fiee it of buttermilk. The cloth is frequently dipped in cold water and wrung dry during the process of "wiping the butter." It is next salted at the rate of an ounce of salt to three ponnds of butter, thoroughly and evenly incorporated by means of the butter-worker. It is then removed to a table, where it is weighed out and put into pound prints. After this it goes into large, tin trays and is set in the water to harden, remaining until next morning, when it is wrapped in damp cloths and placed upon shelves, one above another, in the tin-lined cedar tubs, with ice in the compartments at the ends, and then goes immediately to market. Matting is drawn over the tub, and it is surrounded again by oilcloth so as to keep out the hot air and dust, and the butter arrives in prime condition, commanding from seventy-five cents to one dollar per pound.

Mr. IsaAc A. Calvert, who markets his butter at these high prices at Philadelphia, attributes his success to three points :-1. The food of his cows ; 2. Temperature; 3. Neatness and dainty refinement at every step, from the moment the milk flows from the udder till the dollar in currency is paid for the pound of butter. He says:- "I have found that I make my best butter when I feed on white clover and early-mown meadow hay. I cut fine, moisten, and mix in both corn meal and wheaten shorts. Next to meal I regard shorts, and prefer to mix them together. I feed often, and not much at a time. I do not use roots, unless it be carrots. My pastures and meadows are quite free from weeds. I cannot make this grade of butter from foul pastures or low-grade hay.

"Temperature.-This I regard as a matter of prime importance in making butter that commands a high price. 
Summer and winter I do not permit my milk-room to vary much from 58 degrees. In summer I secure the requisite coolness by spring-water of the temperature of 55 degrees Fahrenheit, flowing over stone or gravel floor in the milkhouse. This can be accomplished without water in a shaded cellar ten feet deep. As good butter can be made without water as with, but the milk and cream must be kept at all times a little below 60 degrees.

"We skim very clean, stir the cream-pot whenever a skimming is poured in, and churn but once a week, summer and winter. Just before the butter gathers we throw into the churn a bucket of ice-cold water. This hardens the butter in small particles and makes a finer grain. In the hot months this practice is unvarying.

"In working we get out all the buttermilk, but do not apply the hand. A better way is to absorb the drops with a linen cloth wrung from cold water. The first working takes ont all the milk; at the second we handle delicately, with fingers as cool as may be. The salt is less than an ounce to a pound, but not generally much less. The balls each weigh one pound, and receive a uniform stamp. On packing for market, each ball is wrapped in a iinen cloth, with the name and stall of the marketman written upon it. Our tubs are made of cedar-plank $1 \frac{1}{2}$ to 2 inches thick and lined with tin. On the inner face are little projections, on which the shelves rest. The balls are not bruised or pressed at all, and pass into the hands of the consumer as firm, as perfect in outline, and as spotlesss as when they left the spring-house.

"We find uniformity to be a prime virtue in the butter-maker. We produce the same article whether the cows stand knee-deep in white clover-blooms or sun themselves on the lee side of the barn in February.

"There is a small ice-chamber' at the end of the oblong butter tub (see Fig. 13) which we use in summer, so that in dog-days the heat within the tub does not get higher than 60 degrees Fahrenheit. I need not add that we observe a scrupulous, a religions neatness in every act and in every utensil of the dairy. Milk which upon leaving the ndder passes through an atmosphere loaded with stable fumes will never make butter for which we can get a dollar per pound. No milk sours upon the floor of the milk-room; none is permitted to decompose in the 
crevices of the milk-pans; the churn is scoured and scalded till no smell can be detected but the smell of white cedar.

"Our customers take the napkins with the prints, wash, iron, and return them when they come to the stand on market days. These are generally Wednesdays and Saturdays. With these prices we have no difficulty in making a cow pay for herself twice a year; if she cost $\$ 60$, we sell $\$ 120$ worth of butter from her in twelve months."

It may be remarked that the sour milk is employed by the Philanelphia butter-makers as a feed for swine. It is estimated that such milk will make $100 \mathrm{lbs}$. of pork per cow.

The cows in the district where the Philadelphia butter is made are well sprinkled with the Jersey or Alderney blood, and about a pound per day from each cow is considered a fair average for the best dairies.

PHILADELPHIA BUTTER PAIL.

The following cuts will illustrate the butter pail and manner of packing for market:

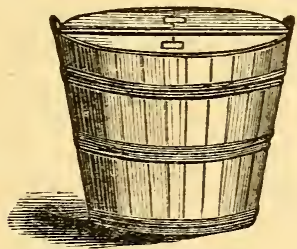

FIG. 13.

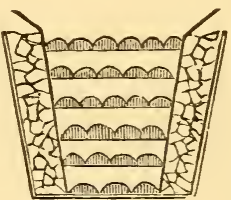

FIG. 13.

Fig. 12 shows the general form of the tub, the top or cover opening in halves. Fig. 13 is a perpendicular section, showing the ice-chamber and ice at the sides and the shelves of butter one above the other in the center.

\section{THE DRY VAULT SYSTEM.}

That good butter can be made on the "dry vault system" there can be no donbt. Indeed, I have tested butter made on this system in numerous instances and found it excellent. What we seek in a good method for setting the milk for cream is an arrangement whereby a low, even temperature of milk may be maintained. There must be good ventilation in order that the animal odor 
or other odors in milk prejudicial to its flavor, may be free to pass off and be wafted away from the milk room. These can be secured in a properly constructed vault; and although the pool and water vat have in our opinion important advantages over the dry vault, they must not be considered as wholly indispensable to the manufacture of first-class butter. U pon farms therefore, where water cannot conveniently be had for pools or for the supply of water vats and large pans, the dry vault may be substituted with reasonable prospect that good butter may result from this plan of setting the milk. And in many parts of the West where running water is scarce, or upon farms that cannot have the proper supply of water near the farm buildings where it is desirable to locate the dairy house, the dry vault may be commended and will be found serviceable for butter manufacture.

iTS LOCATION, ETC.

The best location for the dry vault is upon a rolling or slightly elevated surface, or where there is sufficient descent to insure good drainage. Some soils are gravelly and afford a good, natural drainage, and in such we have seen good, dry vaults erected upon a level surface, a dry well being made outside and a drain carried from the vault to the well. The churn-room may be wholly on the surface, as well as the ice-house, which, when convenient. should be in connection with or a part of the establishment. The size of the vault when the churn-room is on the surface will depend of course upon the size of the dairy. In my tour through Maryland I saw a number of dry vaults in successful operation, and the following description of one where the churn-room is partly below the surface of the ground is given. It was deemed amply sufficient for a small number of cows, say from fifteen to twenty. There was a well of good water near the vault, and pipes were arranged for conducting water into the vault or churn-room, as desired, though no water was employed about the the pans in setting the milk.

\section{CONSTRUCTION OF THE VAULT.}

The milk vault is $11 \times 13$ feet and 7 feet high to the top of the arch. The ground is excavated 11 feet, and by rounding up the earth 4 feet more the arch is 8 feet under ground. This gives a low temperature, and with the 
use of an air tube communicating with the ice house, an even temperature of 60 degrees may be maintained. There is a chimney 18 inclies square rumning from the back end of the arch, and this, with an opening at the bottom leading out through a drain, gives ventilation, so that the atmosphere is kept sweet and pure. The drain also serves for the escape of water. There is a pipe also to let in water communicating with the well outside. On the sides of the milk vault there is a raised platform with trough, all of solid masonry, for the purpose of holding the pans of milk which are set for cream. The pans used are about a foot in diameter, and the space in the trough is wide enough for two pans. The pans hold about six quarts each, and the milk is set six inches deep. The churn-room is several feet higher than the milk-room, a wide stairway leading from one room to the other. It is $9 \times 12$ feet, and has windows which are protected with wire gauze to keep out flies and vermin. The whole structure is built of stone and every part of the room plastered with cement, so as to be impervious to water and to vermin. The subjoined rough draft (Fig. 14) will illustrated the ground plan of the structure.

The cream is churned in summer at a temperature of about 60 degrees Fahr.

\section{MILK CELLAR WITH ICE HOUSE ATTACHMENT.}

Another milk cellar well adapted to farm dairies is that arranged on the plan of Mir. Willias Crozier of Northport, N. Y. In a report by a committee from the American Institute, the following description is given of this structure :

The walls are thirty six by eighteen feet, and it is divided milk varult. into ice house, milk- D, Stairway to the churn room,

room and butter kitchen, as in this plan. Two tubes or conductors go down from the upper part of the 
ice house. They are made of boards eight inches wide and an inch thick, with holes bored in them. The holes allow the cold air to enter from the ice, and it pours in a stream from the mouth of the tube into the nilk-room. The temperature of the air as it comes out at the mouth of the tubes is about 35 degrees. As the milkroom has thiek walls and the windows are high, this flood of air at 35 degrees is able to lower the mercury to 62 degrees, and even lower, in July. Sometimes he closes one tube to keep the room from growing too cold. The draft is the strongest in the hottest weather. In spring and fall there is little current, and in winter, when the fire in the stove is constantly burning, the draft would be the other way. But then the mouths of the ice tubes are closed. By this arrangement the desired temperature is secured the season through, and there is no difference between the June butter and his January butter.

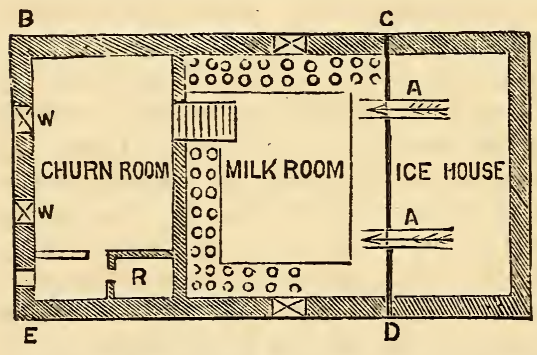

FIG. 15.

Mr. Crozier, in a letter to the Country Gentleman, in referring to the tubes in connection with his milk-room, says: "I lad tubes made of four boards nailed together like a box, filled with holes and placed in the ice exactly opposite the two tiles leading from the dairy into the ice house. As soon as the ice was used down to these tubes, they were taken out and laid aside until the ice went in again the next time, as they would be much in the way of getting in ice or taking it out after we had reached this part of the ice." He adds :- "This is a good thing, any farmer can make one in a few minutes with four boards, an auger: and a few nails without purchasing a patent."

The above cut Fig. 15, will illustrate a milk cellar with the ice house connection arranged very nearly upon the Crozier plan. 
PLAN OF MILK-CELLAR WITH ICE-HOUSE CONNECTION.

$A, A$, are tubes made of boards eight inches wide, extending from the ice-house to the milk-room, for conducting the cold air from the ice. These tubes are perforated with holes. The churn-room is higher than the milkroom and is connected by a stairway leading from one to the other; $R$, is a closet and $W, W$, are windows. The churn-room is provided with sink and pump for water, and the milk-room may have a stove for regulating temperature in cold weather. The cold air from the icehouse may be regulated by opening or closing the tubes so as to maintain a temperature in the room of 60 to 62 degree Fahr. during the hottest weather. The tubes open near the floor and the ice-house is higher than the milk-room. It may be wholly above ground.

\section{HEATING THE MILK-ROOM.}

Some means should be employed for heating the dairy as needed, either by stove or piping for hot water or hot air. There are seasons when the weather is too cold or too damp and the milk will be affected unfavorably unless heat can in some way be applied to comnteract these influences. A record should be kept of atmospheric changes. Mr. S. E. Lewis of Oxford, N. Y., says: "When the weather is clear and the wind northwest, there will be good cream, but in unfavorable weather the butter globules do not readily rise. Milk knows south wind sooner than the dairyman knows it, so sensitive is it to atmospheric influences. Start a fire in damp days, so as to keep the atmosphere dry in the milk-room."

ARTIFICIAL HEAT IN THE MILK-ROOM COUNTERACTS THE INFLUENCE OF THUNDER STORMS.

From experiments made in Sweden, it appears that a fire started in the dairy when a thunder storm is seen approaching, will counteract, in a great degree, if not wholly, the well known influence which such storms ordinarily have upon the milk in hastening its acidity. Even in the hottest weather, on the approach of a thunder storm, a fire is recommended to be started in the dairy. The reason for this is, that the damp, moist, heavy air resting on the milk, proves injurious. Remove this air by any means, and the milk will keep. Dry air 
is important in the dairy. An excess of dry air is not injurious, hence dairy rooms should always be well ventilated.

\section{SCALDING THE MILK.}

The plan of scalding the milk soon after drawing from the cow, in order to facillitate the rising of the cream, has been known and practiced from time immemorial, in the treatment of late fall and winter milk. The usual method was to set the pans containing the milk in a vessel of hot water on the kitchen stove and when it is heated to a temperature of 130 to 140 degrees Fahr. it is removed to the milk cellar or the dairy-room and set aside for the cream to rise. Under this treatment the cream comes up speedily and is more easily churned than when the milk is set in the ordinary way. Somewhat recently the plan of heating milk, soon after it is drawn from the cows, to a temperature of from 130 to 140 degrees Fahr., during fall, spring and winter, has been gaining favor with certain fancy butter makers, who speak highly of the practice, and say that the butter from this process meets with ready sales as a fancy product. The heating expels animal odor, to some extent, and in connection with aration, will, without doubt, improve imperfect milk, or that which is tainted with odors.

In 1870 Prof. George C. Caldwerl, of Cornell University, brought prominently before the dairy public, the "germ theory" of Pasteur, Hallier, and other scientists, as to the cause of fermentation, and upon this theory we can see how heat would have a tendency to destroy the spaces or seeds of certain minute organisms found in imperfect milk, thus arresting decomposition. The heating of milk of this description, therefore, has been urged as improving its condition. The milk after scalding is set aside in the dairy, and kept at a temperature of about 60 degrees Fahr. To enable farmers and factorymen to carry out this process of heating, whenever thought desirable, Messrs. Bunneli \& BRown of Guilford, N. Y., have adapted a heater and connecting pipes to their "Iron Clad Milk Pan." By this arrangement, as well as by the usual cold water pipes attached to the pans at the same time, the dairyman is prepared to adopt either the scalding of the milk and cooling to 60 degrees, or the usual practice employed for setting the milk when 
large pans are used. The cut, Fig. 16, gives an illustration of the Iron Clad Pan.

This is one of the best pans in use the water circulating freely and evenly under and around the pan, while the pans can be easily taken out of the rat and put back again. The pipes to the pans are easily detached, and can be taken off to be cleaned if necessary, while the milk remains in the pans.

\section{THE DEVONSHIRE PLAN OF} SCALDING MILK.

In Devonshire the dairy house is either of stone or brick, and is usually in connection with the dwelling; stone floors and stone benches for the milk to set upon and all well ventilated and kept scrupulously neat and clean. The milk as it comes from the cow is strained into large, deep pans and put in the dairy, where it stands firom eight to twelve hours and sometimes longer, when the pans are taken out, care being taken not to agitate the cream that lias risen, and the milk scalded by placing the pans holding it in an iron skillet filled with water and set upon the range. At the bottom of the skillet there is a grate on which the pan of milk rests, so as to keep it from the bottom and prevent burning. The milk

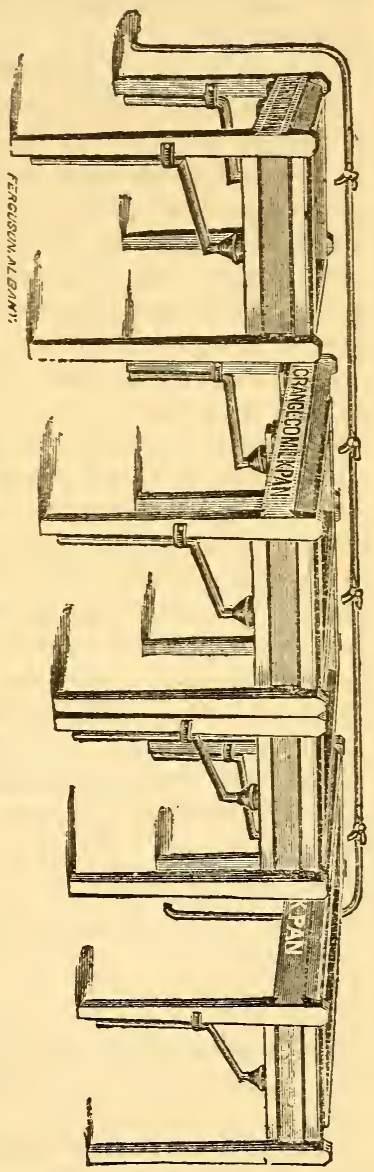

FIG. 1?: is slowly heated to near the boiling point, or until it begius or is about to boil. When the cream begins to show a a distinctly-marked circle (or crinkle) about the outer edge and the first bubble rises on the surface of the cream, it must be immediately removed from the fire. Some 
experience is necessary in applying the heat to have it just right, otherwise the cream is injured. When properly scalded, the milk is removed to the dairy, where it stands fiom 12 to 24 hours, according to the condition of the weather, when the cream is removed and is in a thick, compact mass, being an inch or more in thickness. It is more solid than cream obtained in the usual way, and has a peculiarly sweet and pleasant taste. In skimming, the cream is divided with a knife into squares of convenient size and removed with a skimmer. This is the famous clotted (or clouted) cream, considered in England as a great delicacy, and is largely used with sugar upon pastry, puddings or fiesh fiuits and especially upon gooseberry pie. It makes an extensive article of commerce and is really a delicious kind of food. The milk thus treated yields about a fourth more cream than is produced in the common way, but it is mainly at the expense of the remaining milk, which has parted with more of its caseine than milk treated for cream in the ordinary way. It is more readily chumed than common cream, and I hare often seen the Deronshire dairymaids do the churning by placing the clouted cream in a large earthen ressel, and by simply stirring the cream with a wooden paddle for a few minutes. The butter has something of the taste peculiar to the clouted cream and is highly esteemed by those who are accustomed to its use.

\section{WILKITSOY'S GULF STREAM REFRIGERATED DAIRY-ROOM.}

The most recent invention for regulating the temperature of the dairy is that of Prof. JонN WiLinsox, the well-known architect of Baltimore, Md., and the descrip. tion of the plan and its operation will be of interest. The plan for a perfect control of temperature and at the same time securing ample ventilation, meets a want which has long been unsupplied: Mr. W. has been granted letters patent on this invention. 
This system of dairy-room construction has two distinctive characteristics, both operated by the same natural law, Gravitation. One consists in the displacement and circulation of air, and the other of water; the former for both cooling and rentilating the apartment; the latter for cooling only.

The device for conjunctive cooling and rentilating is very peculiar, unique and strictly automatic in its action. It consists in constructing the building with hollow walls, or with close air chambers, between the inner and outer walls; the windows are to have inner and onter sash, with confined air between then; and there are to be no places for the ingress or egress of air, except those hereiu described.

All the air supplied to the apartment is admitted by natural movement through ducts, or pipes, laid in the ground at a depth to be secure from the effects of both sun and frost. One of said ducts requires to have a fall or slope toward the building, and the other from it; ordinarily, each duct requires to be abont 100 feet in length and to be laid five feet below the surface of the ground.

\section{THE ACTION OF THE DUCTS.}

All the terminals of the ducts being open, air will circulate through both ducts and through the building at all times.

The direction of the air in the ducts depends entirely on the temperature of the externa? atmosphere. When said air is warmer than the earth, the cooler and more dense air in the ducts will, on account of its density, flow down into the building, thence throngh it and the lower duct, and will be discharged on the surface of the ground below the building. Thus it will be apparent that air is taken into the building at the temperature of the earth, or about 62 degrees. As the ducts are arranged in the diagram, if the temperature of the air in the bnilding is higher than that of the air flowing through it, it will cool and change only the stratum near the floor.

If it is desirable to cool and change the air of the apartment to any particular point between the floor and the ceiling, it is only necessary to insert into the egress duct a joint of portable pipe of a length that will exhaust 
the air at the requisite hight, when all the air below that point will be cooled and the circulation and ventilation will continue the same as before the perpendicular length of pipe was added.

\section{REVERSING THE CIRCULATION.}

Whenever the respective temperatures of the external atmosphere and of that in the ducts is reversed, or when the out-of-door temperature is lower than that of the earth, heat will be absorbed by the air in the ducts from the earth in which they lie, and being rarified and rendered more buoyant, it will rise through the lower duct to the building, thence through it and the upper duct, and will escape at the highest point.

By this means circulation and ventilation is automatically maintained at all seasons, and thorough and constant change of the air of the apartment is secured; and, moreover, a uniform temperature is obtained summer and winter, without artificial heat, or the use of ice or cold water.

In warm weather the duct, being cooler than the external atmosphere, a portion of the moisture in the air will condense on the interior surface of the duct, and when it increases to that degree that it flows in the pipe, it is received into drip wclls, with earth bottoms, and is absorbed. The air coming in contact with the moist surface of the duct, is effectually freed from dust and otherwise improved in its hygienic condition, which characteristic of the system can scarcely be over-estimated.

\section{SALUBRITY SECURED.}

A temperature most desirable in a dairy-room is objectionably low for the health and comfort of the manipulator, who is at times exposed to a sudden transition from a very high to a very low temperature, and vice versa. This serious objection is entirely removed in the proper use of the subterranean system of ventilation. The circulation of cooled air may be confined to a thin stratum near the floor, while all portions of the air of the apartment above that point may be kept at any temperature most desirable. No characteristic of this system is more highly estimated by persons familiar with hygienic laws than that last described. 
A SUPER-COOLING DUCT.

Another characteristic of the system of subterranean ventilation, more highly prized by many than any other, is the powerful cooling adjunct, consisting simply of a branch of the summer-supply duct, which is laid in a cold air chamber, under an ice-house located contiguously to the diairy-room. or apartment to be cooled.

By closing a valve on the end of the direct, warmweather supply duct, and opening that on the end of the super-cooling duct (both accessible in the apartment), all the air admitted must pass through the super-cooled branch duct, which may be made to supply air at the tenperature of 40 degrees or lower ; and by adjusting both valves the temperature of the air admitted may be modified to any degree desired, between forty and sixty.

The inventor, who is proverbial as a utilitarian, claims that to secure super-cooling as above described, necessarily involves the use of more or less ice, and a proportionate expense, and that there is in ice-houses, as ordinarily arranged, a waste of cooling power that he has saved in his "Gulf Stream" water bath, and by utilizing said waste he avoids unnecessary dranght on the ice and at the same time secures a more rapid system of cooling, when it is desired. Both systems are covered by the patent, hence he supplies both, and they may be used separately or conjunctively, as may be preferred.

The accompanying engravings are copied from drawings furnished by the inventor, and the reference descriptions are prepared by him:

Fig. 1 represents a ground-floor plan of the "Gulf Stream Refrigerated Dairy Room," with an Ice House contiguous.

\section{REFERENCES.}

A, stairs leading to scullery, D; B, the dairy room; $\mathrm{C}$, the floor of the ice-house, on which the ice rests; $a$, that portion of the gulf stream, water bath of which is in the floor of the dairy; $b$, the portion of the bath which is in a cold air chamber, beneath the ice, and the bounds of it are denoted by the figures 1,2, 3 and 4 ; the dimension figures denote the superficies of the bath. A row of cans in the bath is shown by the circles, and one can 


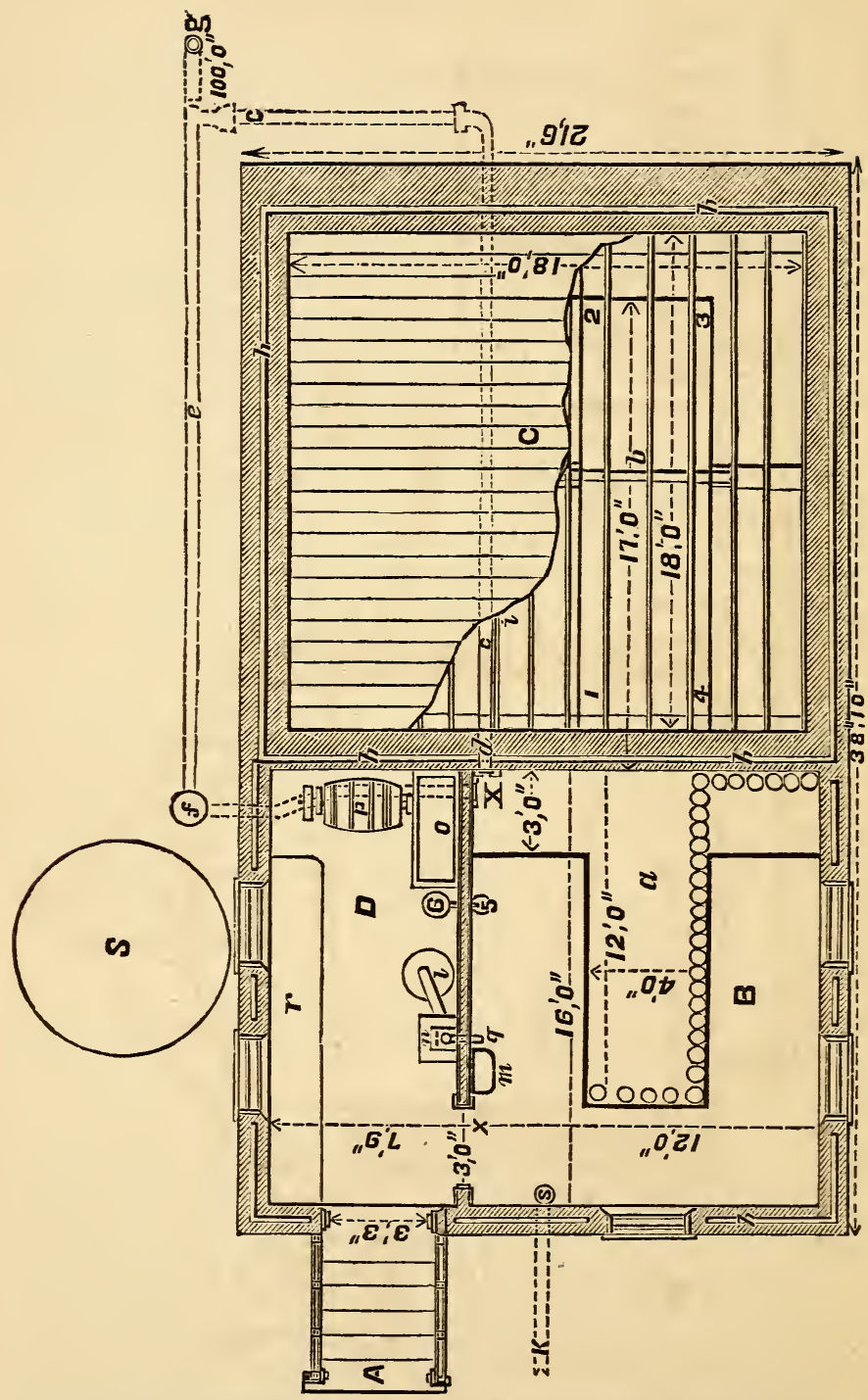

FIG 1-GULT STREAM DAIRY ROOM-GROUND FLOOR PLAN. 


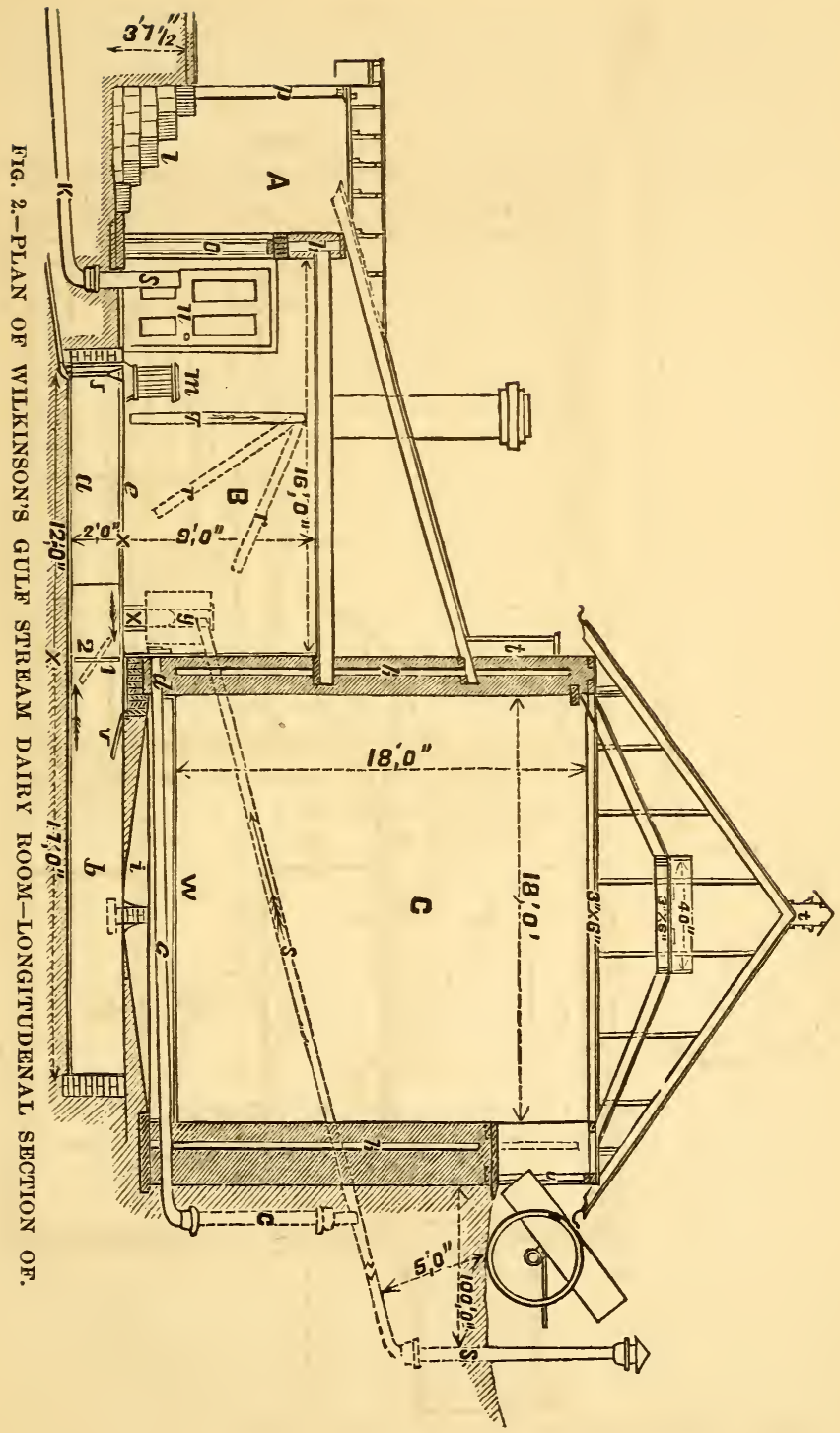


marked 5 , is set to receive strained milk from the straining can, 6. By using cans eight inches in diameter and twenty inches in depth, the capacity of the bath is 500 gallons; $c$, the super-cooled branch of the summer supply duct, with a valve at $d ; e$, the main summer supply duct, with its drip well $f$, its perpendicular part $g$, and its valve at $\mathrm{X} ; h$, air spaces in walls; $i$, cold air chamber; $J$, overtlow of water bath; $K$, summer egress duct, opening perpendicularly at the floor; $l$, steam generator; $m$, radiator for heating dairy; $n$, chimney; $o$, sink; $p$, churn; $q$, adjustable metal ventilating pipe, to be used as an exhaust, or egress pipe, if the peculiarities of the site require it; $r$, work table; $\mathrm{S}$, rain water cistern. The walls represent brick and stones, the narrowest $4 \frac{1}{2}$ inch; the medium, 9 inch bricks and the widest an eighteen inch stone wall. The building may, however, be built of any material most economical. As the cold water bath will not be required in winter, it may be floored over with movable floor, and the same space be used for setting the milk in air. It will be seen that all the manipulation of the milk and butter, except setting for raising cream, is performed in the scullery. The joists shown in the icehouse floor are to be $3 \times 12$, and the plank of said floor are to be 2 inches in thickness. The floor of the cold air chamber is to be of cement, plastered on the earth; the object being to make it impervious to water, and it having a suitable drip, discharges the water from the melted ice into the water bath, and is its only source of supply.

Fig. 2 represents a longitudinal section of the entrance and stairway, A ; the dairy-room, B ; and the ice-house, $\mathrm{C}$; $a$, that portion of the water bath in the floor of the dairy, and $b$ an extension of the same into the cold chamber under the ice; $c$ the super-cooling branch of summer supply duct, with its valve $d ; e$, the floor of the dairy; $h$, the air chambers in walls; $i$, the cold air chamber under ice; $K$, the duct having a fall or slope from the dairyroom, which duct is the egress duct in summer; $l$, the stone steps; $m$, a radiator for heating the dairy; $n$, door between the dairy and scullery; $o$, doorway to scullery, and $p$ the outer door ; $q$, an adjustable ventilating pipe, connecting with the smoke flue. This pipe, in the position shown, exhausts the air from the dairy from a 
point near the floor, but in case it is desirable to exhaust it from a higher point the pipe may be turned to positions shown by $r ; s$, shows the position of the main summer supply duct; $t$, ventilators on roof of dairy, and on that of ice-house; $u$, door for filling ice-house; $v$, a floating hinged valve, which rises and flalls with the water in the bath, and prevents air from flowing from cold chamber into dairy-room. W, floor of ice-house; $\mathrm{X}$, valve on discharge end of main supply duct branch, leading firom the drip well $y$. 1 is a rocking valve in an erect position, so arranged that it forms a partition across the water bath, and prevents the circulation of the water, as it would circulate without said valve, on the gulf stream principle. When it is desirable to have water circulate for cooling the bath in the dairy, the valve is set obliquely, as shown at 2, and the colder water from under the cold chamber will flow along the bottom of the bath, in the direction shown by the lower arrow, and the warmer water from within the dairy will flow into the cold chamber, as shown by the upper arrow. The circulation is checked and controlled by adjusting the valve, and the temperature of the water in the dairy is automatically maintained at any desired degree. The difference in the density of the water under the cold chamber, and of that in the bath in the dairy, causes a tendency to circulate until an equilibrium is established, but the equilibrium temperature would be too low for setting milk, hence the necessity for the valve for controlling the circulation, which may be done with the greatest nicety. It will be seen that there is a sub-roof, or raised ceiling over the ice. On this, the non-conducting material is to be placed, instead of putting it directly on the ice. The hollow walls serve as sufficient protection to the sides of the ice-house. With this arrangement, the labor and cost of material used in protecting the ice from heat, has to be borne but once, instead of annually, no small item of economy. 


\section{POINTS CONCERNING BUTTER MAKING.}

At the meeting of the New York State Dairymen's Association at Binghamton, 1874, Mr. Samuel E. Lewis, of Chenango Co., N.Y., gave the following points, which we think are worthy of study and observation by the Butter Dairyman :

\section{CONCERNING ACIDITY.}

In the manufacturing of butter the first point is good cows and then good feed, and the next the setting of the milk. Milk is almost as sensitive to atmospheric changes as mercury itself. It is a question among many as to what depth milk should be set to get the most cream. It does not make so much difference as to the depth, as it does the protection of the milk from acid or souring. As soon as the acid strikes the milk the cream ceases to rise. Many have seen milk sour and whey off in twelve hours' time, with little or no cream on it. The reason of this is that the acid commences to develop itself in the milk before the animal heat leaves it, hence there is no cream.

With a clear, dry atmosphere the cream will rise clean in the milk; but in that condition of the atmosphere that readily sours the milk, the cream will not rise clean, but seems to hang in the milk, and this even when the milk is protected from the acid by being set in water.

The benefits of setting milk in cold water are, that the water protects the milk from the acid until the cream has time to rise. For cream to rise readily on milk set in cold water, the atmosphere in the room should be warmer than the water. There will as much cream rise on milk set in cold water in one hour as there will on milk not set in water in twenty-four hours.

In skimming the cream off from the milk there should always be milk enough skimmed in with the cream to give the butter, when churned, a bright, clean look. Butter churned from clear cream itself will have an oily or shiny look when it comes in the churn. Cream skinmed from different milkings, if churned at the same time, in 
one churn, should be mixed eight to ten hours before churning, then the cream will all come alike.

WHITE SPECKS.

White specks in cream are caused by too much acid in the cream. It is in one sense cheese curd; for butter packed with white specks in it will, after a time, have a cheese smell.

White specks occur in butter in the spring-one kind is found with cream still sweet-specks like hard curd; strain them out, else your butter will have a cheesy taste; the second kind is caused by acidity, which progresses by keeping; and in cream acts. like renuets, converting cream into curd; churn before acid develops and you avoid white specks; the third cause is an advanced state of the second; cream should never stand in a room where the milk is set, but should be put into a cool place if you would avoid specks.

\section{CONCERNING THE KEEPING QUALITIES OF BUTTER.}

In my opinion the keeping qualities of butter depend principally upon two things. First, the buttermilk must be all got out; and, second, the grain of the butter should be kept as perfect as possible. Butter should not be allowed to be churned after it has fairly come, and should not be gathered compact in the churn to take out, but the buttermilk should be drained from the butter in the churn, through a hair sieve, letting the butter remain in the churn. Then take the water and turn it upon the butter with sufficient force to pass through the butter, and in sufficient quantity to rinse the buttermilk all out of the butter. With this process of washing the butter the grain is not injured or mashed, and is thus far kept perfect. And in working in the salt, the ladle, or roll, or worker, whatever it is, should never be allowed to slip on the butter; if it does it will destroy the grain; but it should go upon the butter in a pressing or rolling motion.

Butter should never be hurried in the packing, but should have time to cure, and time for the salt to dissolve; for the chemical action of the salt will, after a time, separate the buttermilk from the butter. 


\section{DEEP OR SHALLOW SEITIYG OF MILK-ASSOCIATED}

DAIRYING, E'I'C.

The question of " deep or shallow setting," in order to get the best results from the milk, has been the subject of warm discussion between the advocates of the pool and large pan system, and is regarded by many as a "mooted question." Before the pail and pool plan of setting milk came into practice, writers on the dairy laid it down as a principle that the cream globules could not rise through a greater depth of milk than five or six inches, and this for many years was universally accepted as true. The "pool and pail system," however, showed this to be a fallacy, and many who had taken the old statements of writers, supposing them to be authorities, were astounded when they saw the practical operation of deep setting and the superior quality of butter it produced. I was the first to bring the "pail and pool system" into public notice, in editorials in the Utica Herald, in addresses before the dairy associations and in pamphlets published by the New York State Agricultural Society, and I well remember the incredulity with which old butter makers looked upon this innovation. But the pails and pools had so many advantages over the common small pans, then in universal use, that the new practice, as I had anticipated, was destined to gain favor and become widely extended. Subsequently, however, the large pan system was introdnced and the controversy soon after sprung up as to which plan of setting, deep or shallow, would produce the most butter. And although many of the advocates of the pool and pail will not admit that shallow setting will give a larger quantity of butter, the weight of testimony seems to be in favor of the latter. It is pretty generally admitted, however, that the deep setting gives a finer quality of butter, and as it has other advantages in connection with "skim cheese" manufacture, it will always be a favorite mode of setting 
where there is plenty of cool spring water and the skim milk is made into cheese.

\section{ASSOCIATED BUTTER DAIRYING AND THE " POOL AND}

\section{PAIL" SYSTEM.}

The American system of associated dairies was inaugurated during the early part of 1851. Though more than twenty years have elapsed since the plan was conceived, the leading features of the system remain unchanged. Great improvements, it is true, have been made in buildings and dairy apparatus and in the methods of manipulating milk for cheese and butter manufacture; still, in organizing factories, in the manner of delivering milk, in the relation between manufacturer and patron, in the care and disposal of the product-indeed, in all the general outlines of the system-it is the same to-day as when Jesse Williams in 1850, mapped it out for the first cheesefactory which he erected early the following year.

In the original plan of Mr. Williams it was not contemplated to apply the system to butter manufacture. But the success of the cheese factories singested to the butter dairymen of Orange county, New York, such a modification of the system as would adapt it to their branch of business.

The whole farming population of this county had for eighty years, or more, devoted its chief attention to butter-making and the furnishing of fresh milk for the New York market. From so long attention to a specialty, the butter of Orange county, as was to be expected, was of fine quality, acquired a high reputation, and commanded better prices than any other brand made in the State. By adopting, however, the associated system, together with a new plan for setting the milk and obtaining the cream, the product rose to the highest point of excellence, and in consequence extraordinary prices were paid for it.

\section{ORGANIZING FACTORIES.}

The plan of organizing factories is somewhat similar to that employed in the cheese districts. The first effort of organization in a neighborhood, generally falls upon one or two persons, who may be desirous of having a factory where they can deliver the milk from their cows, and have it manufactured. They go and 
talk with their neighbors, and finally call a meeting at some central point in the neighborhood, where all are invited to come and discuss the advantages and disadvantages of the system.

The cost of erecting a good factory, and supplying it with machinery and dairy appliances, is from two to four thousand dollars, and the farmers of the neighborhood are expected to join together, and pay for the erection of the buildings, in proportion to the size of their farms, or number of cows from which milk is to be delivered. The shares are put at firom ten dollars to fifty dollars each, so as to be within the reach of farmers who have but few cows.

After the stock shall have been subscribed, a meeting is called, officers are chosen, and powers are delegated for the erection of the building, and for putting it in operation.

The structure being completed and furnished, a superintendent is chosen, and help hired for running the factory ; and the expenses are shared by the stockholders in proportion to the amount of milk delivered. The cost of repairs, additions, \&c., from year to year, is added to the expense account.

The price charged for making the butter usually ranges from four cents to five cents per pound, and when skim cheese is made from the skimmed milk, two cents per pound is charged for the making and care of the cheese, including packages and furnishing supplies.

\section{THE NEW DEPARTURE IN FACTORY MANAGEMENT.}

Some changes are being gradually made in the factory system which promise to be an additional improvement in conducting the business of dairying. The old plan, and that on which most of the factories are now managed, is to make the factory a "joint stock affair," among the farmers of a neighborhood, or perhaps one person will build a factory on his own account and manufacture the butter and skim cheese at a certain rate per pound, the patrons in both instances holding the butter and cheese in their own right and selling it from time to time in bulk together. Sometimes a committee and sometimes only one person is entrusted with the sales. The sal esman usually gets a small compensation for his services. 
It will be seen that this system is somewhat complicated, since it necessitates a division of the business into several separate bran ches and each branch requires a competent agent or manager, to secure which often takes more money than can well be afforded. Now, if the establishments were organized on a plan by which the farmer treats directly with the factory-that is to say, simply delivers his milk and gets his pay for it on some basis of highest values-there would evidently be an improvement in the system, because it would relieve the farmer from the machinery entailed on the several branches alluded to and there would be less liability to loss. 'This is the new plan or change to which I have referred.

Responsible parties are now taking hold of the factories and managing them as a business. The factories are owned and managed on the same principle as the manufactories of cotton, wool, iron, \&c. The raw material or milk is purchased at the factory and the farmer has no further interest in it. The product manufactured is under the complete control of the proprietor of the factory. He disposes of it as he sees fit, either in the home or foreign market; and having a large quantity and being solely interested in the sales, he makes it his business to keep posted in regard to the markets, and consequently better prices are on the whole obtained. By having a sufficient number of factories to manage, the party or parties owning the property have a business that keeps them regularly employed, and of course the profits are sufficient to make it an inducement to manage all the details in the best manner. Take, for instance, a company with twenty factories. The supplies can be bought by one person and the product can be sold by one person with vastly more economy than on the old system, where from twenty to forty persons are employed to do the work, Again, the manufacturers and help employed at the different factories are all under the control of one head or one firm which is constantly overlooking their work, hence any error, waste or extravagance is quickly corrected by an executive that has the power of compeling obedience at once withont "dilly-dallying" along with committees, and waiting for the slow action of patrons, as on the old system, thus necessitating losses from inferior or damaged goods, as is often the case. In 
fine, it is attempted to apply the same principle of economy in massing factories together as has been brought about in massing the farm dairies of a neighborhood together in one factory. The price paid for milk is based upon the value of milk were it made into cheese, that is to say, the factories pay two cents less than the highest quotations for "fancy cheese in New York City for every 10 pounds of milk. In other words, it is assumed that 10 pounds of milk, on an average through the season, will make one pound of cheese. Hence if the best "fancy" cheese in New York city, is quoted at 16 cents per pound the farmers are paid 14 cents for every ten pounds of milk delivered at the factory. The settlement is made the first of every month, and the average of the quotations during the month is taken. Thus, for instance, the May milk would be regulated by the June quotations, since if the May milk was made up on the old plan it would not get into market until June, and so on during the several montbs of the year.

By purchasing the milk direct from the farmer the business, it would seem, is less complicated, and so far as tried has proved satisfactory to the dairymen as well as to the proprietors of the factories.

\section{CREAMERY PRACTICE-PAIL AND POOL SYSTEM.}

As the "pail and pool" system originated in Orange county, and as this plan of butter making has not changed materially, though now widely distributed in other localities, it will be proper to give a brief account of the early factories.

The first American butter factory was erected by Mr. Alanson Slaughter, near Goshen, Orange county, New York. The main building is a cheap two-storied structure, arranged on a plan similar to that of the cheese factories. On the ground floor are the milk vats, presses, and other appliances for making cheese, while the second floor is entirely devoted to the dry-room, or department 
for storing the cheese during the process of curing, \&c. See Fig 17.

The spring-house is built out upon the end of this structure, forming a wing, and is one story high. It is
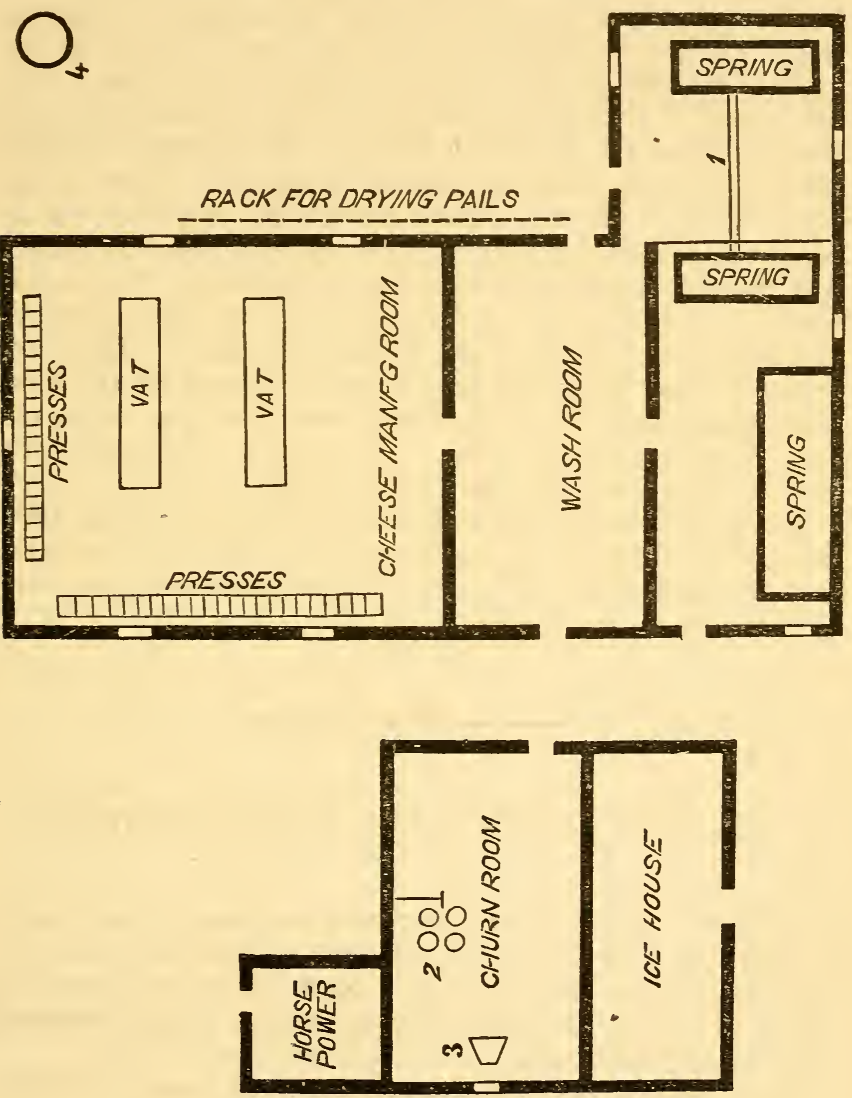

FIG. 17.

divided into two rooms, one 12 feet by 16 feet, and the other 14 feet by 24 feet. The packing and churning room is in a separate builling, 12 feet by 24 feet, and stands opposite the spring-room, with a narrow alley between. This alley is used for a horse-walk where the 
teams deliver milk and cart away the products of the dairy. Connected with the pacizing and churning department there is a horse-gear for churning, and an icehouse and store-room.

THE SPRINGS, AND THE MANNER OF TREATING MILK.

In the earlier factories erected, the springs are situated within the enclosure of the spring-house, and vats or tanks are constructed about the springs for holding the water. These pools are each twelve feet long and six feet wide. The earth is excavated, and the sides of the pool are laid up in solid masonry, or with stout oak plank, so that the water in the pools shall rise no higher than the level of the floor of the spring house. Near the bottom of the pools racks are arranged for holding the cans or pails of milk; the water flows up through these racks and above them to the hight of seventeen inches.

When a spring cannot be had in the spring-house, the pools are sunk below the level of the floor and arranged in the same way as above described, except that the bottoms are cemented tight, covered with flagging or oakplank, and the water conducted from the spring through pipes. The pails for holding the milk are of tin, fiom twenty to twenty-two inches in length and eight inches in diameter. In furnishing a factory, two pails are required for each cow's milk delivered.

As fast as the milk is received the pails are filled within four or five inches of the top, and immediately placed in the water. Care is taken that the surface of the milk in the pails is not above that of the water in the pools. The pails are set close together, and each pool has capacity for holding 2,040 quarts of milk. There should be a constant flow of water in aud out of the pools, and the flow should be sufficient to divest the milk of its animal heat after reaching the factory in less than an hour.

Some experiments have been made with a view of determining at what temperature the water in the pools enables operations to be conducted with the most success; and the best results in cream (quantity and quality considered) are obtained when the natural temperature of the water flowing into the pools is abont 56 degrees Fahr. The pools should not be kept, at so low a temperature as 
48 degrees, nor much, if any, above 57 degrees. The range of temperature desired by sonie is from 56 to 60 degrees. It is claimed that more cream, and that of better quality for butter making, may be obtained by setting the milk on the above plan than it will yield when set shallower in pans and exposed to uneven temperatures.

One feature in the process, deemed of great importance, is to expose as little of the surface of the milk to the air as possible, in order that the top of the cream may not get dry, as this has a tendency to fleck the butter and injure the flavor. The milk of one day is left in the pools until next morning, which gives twenty-four hours for the morning's mess and twelve hours for the evening's mess to cream: The pails are then taken out of the pools and the cream dipped off. In removing the cream a little tunnel shaped cup, with a long, upright handle is used (see Fig. 18), and the thin cream is dipped off down to the milkline, which is readily recognized by the blue appearance of the milk.

In the fall and spring of the year the cream, as it is dipped, often goes immediately to the churns, and is churned sweet. In summer the cream is dipped into the pails and returned to the pool and kept there till it acquires a slightly acid taste, when it is ready for the churns.

The cream having been removed, the skimmed milk in the pails is now turned into the cheese-vat to be made into "skim-cheese." The pails then go to the washroom, where they are thoroughly cleansed with soap and water, and set upon a rack exposed to the sun and air. At some factories the pails, after being cleansed with soap and water, are placed over a jet of steam and thoroughly scalded. They then receive a jet of cold water and go upon the rack to sun and dry. This arrangement is a very great improvement in cleansing dairy utensils, doing the work thoroughly and expeditiously.

The factories do not all onerate alike in regard to the time of setting the milk. Where an extra fancy product of butter and skimmed cheese is desired, none of the milk 
is set longer than twenty-four hours, and at these fitctories it is not desired to take all the cream from the milk, but only the best part; and the balance is employed to give quality to the "skim-cheese." At some establishments the cream is allowed to turn slightly sour before churning; but when it is churned sweet the buttermilk goes into the vats with the skimmed milk and is made into cheese. Some factories adopt the plan of holding the morning's milk in the pools for thirty-six hours and the night's milk for twenty-four hours; but as the skimmed cheese by this management is less meaty than by the other method, it is a question whether any more profit is realized from it.

\section{CHURNS AND CHURNING.}

From experiments with different kinds of churns, many factory butter-makers are of opinion that for quantity and quality of product from a given quantity of cream, the dash churn is to be preferred.

At the factories the barrel and a half or "two-barrel size" is preferred; and the churns should be made with as little bilge as possible. During the churning it is thought desirable to keep the cream from rising above 60 degrees in temperature. When the churns are started, the temperature of the cream should be about 56 degrees; and it has been found that the best results are obtained when the dashers make from 40 to 42 strokes per minute. At this rate of stroke, and no less than one hour being consumed in the process of churning, if the temperature of the cream be kept below 60 degrees, or no higher than that, the butter will come of good color and texture, and will be in the right condition for a first-class " fancy product," at least, so far as it can be made by the operation of churnirg. It is important, of course, that the cream be in the proper condition when it goes to the churn; but the manner in which the churning is conducted las a much greater influence upon the product than many people imagine.

The agitation of the cream over the whole mass should be as even and uniform as possible, in order that all the cream may be turned into butter at about the same time. If the agitation is too rapid, or if it be unevenly distributed through the mass, a part of the cream will come to butter 
while a part will remain unchanged, and by the time the whole mass is churned, the particles of butter first formed will have been beaten up in the agitation so as to injure the texture; or portions of unchurned cream may become mingled with the butter, thereby not only lessening the quantity of butter from a given quantity of cream, but materially injuring its quality. Again, in order to preserve a nice Havor and color, as well as fine texture, the mass of cream while churning must not be allowed to rise to a high temperature.

It will be seen, then, to regulate all these points, the proper coustruction of the churn-dasher is important. Numerous experiments have been made with differently formed dashers, and fiually a form has been hit upon that gives much better results than the old form of dasher heretofore used. I give an illustration (Fig. 19) of the

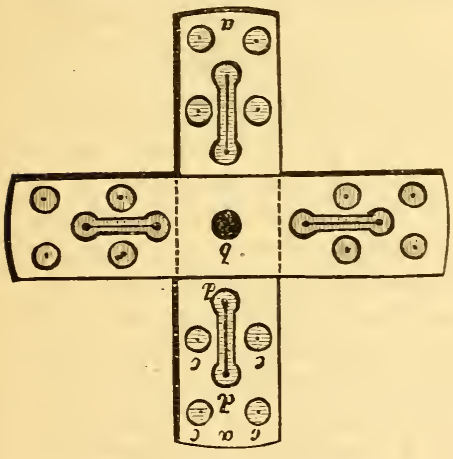

FIG. 19-The improved Churn-Dasli (lower side.)

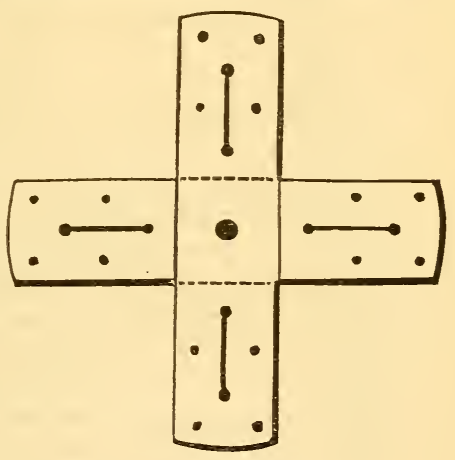

FrG. 20-The improved Churn-Dash (upper sidc.)

dasher, and its proportions as adapted to the "two-barrel churn." The two pieces $a \alpha$ forming the dash are 20 inches long by 6 inches broad.* They are halved together in the center so as to form a cross, the handle of the dasher going through both pieces at $b$. The holes $c c$ are made by boring with a $17-8$ inch bit into the arms, but not quite through. Then in the center of this cavity a 5-8 inch hole is cut through the arm. The holes $d d$ are inade in the same way, and a slot connecting the two is

* In this cut the engraver has not represented the right proportions, the pieces forming the dasher being too narrow for their length. 
cut partly through the timber, in the center of which : narrow slot goes entirely through the arm. This forms the lower side of the dash, the upper side being shown in Fig. 20.

In a recent tour among the butter factories, I saw the churns in operation with the improved dasher, and with other shaped dashers; all were worked at the same time, and with the same power, and it was plainly evident that the improved clasher did the best work, while

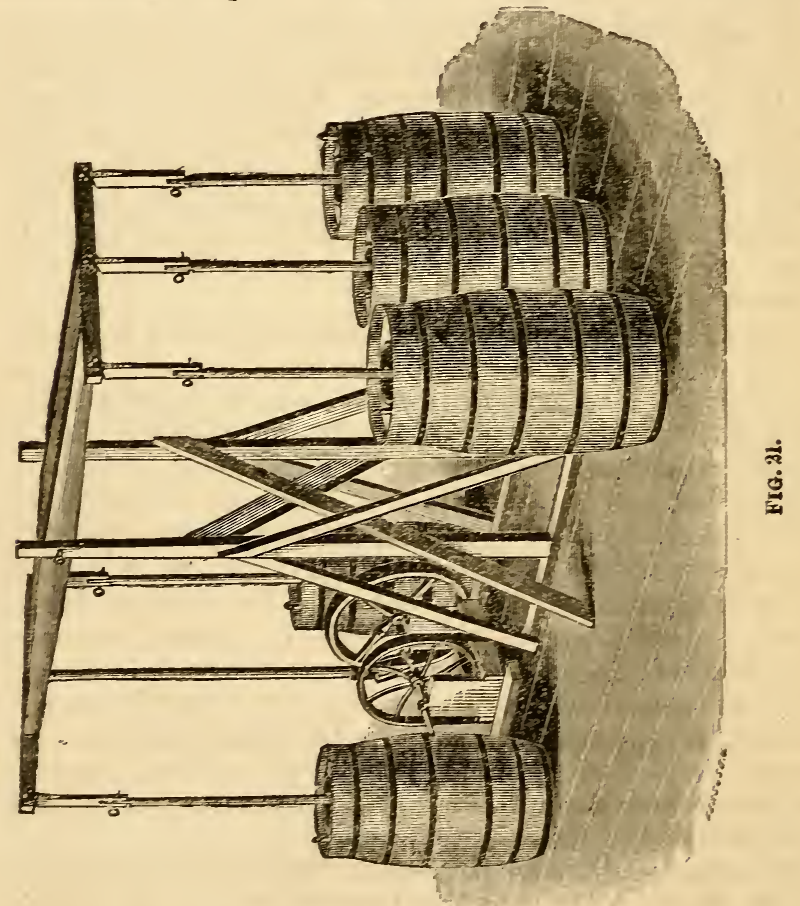

the temperature of the cream, which I tested from time to time, was more even and lower than in the other churns. In some districts the large dash churn is constructed with a hoop at the top 10 receive the churn cover. This causes considerable trouble in cleansing, as particles of cream and rilk are liable to work down 
between the hoop and staves, thereby bccoming foul, unless extra care and labor be taken in cleansing. In the Orange County factories a part of the staves is cut away to receive the churn cover, thus doing away with the cumbersome hoops, and rendering the churn neater in appearance, and more easily cleaned.

The cut on preceding page, Fig. 21, will illustrate the manner in which the churns are attached to the motive power.

Usually, four (of the dash-churns) churns are placed in pairs opposite, or two side by side, so as to be all worked by the power at the same time. From sixty to seventy quarts of cream are put into each churn, and each mess of cream then receives from twelve to sixteen. quarts of water, for the purpose of diluting it and bringing it to a temperature of about 56 degrees to 60 degrees. In warm weather cold spring water is used, and in cold weather warm water.

Some prefer diluting the cream with water and passing it through a sieve before putting it in the churns, in order that the particles of cream may all be of uniform size; since if the butter does not come evenly, but is mixed with small particles of cream, it will soon deteriorate, and will not make a prime or fancy article. This point is considered of great importance by the best butter makers, and it is claimed that the method of setting the milk in deep pails, by which a thin cream is obtained, rather than the thick, leathery masses skimmed from milk set in pans, renders it more evenly churned, and thus secures a better product. It is partly on this account, also, that it is preferred to have the churning occupy from half to threequarters of an hour, since it has been found that when the butter comes too quickly it is more or less injured.

In warm weather ice is sometimes broken up and put in the churn to reduce the temperature of the cream; but it is deemed better to chmm without ice, if the cream does not rise above 64 deg. F. in the process of churning, as butter made with ice is believed to be more sensitive to heat. It is, howerer, a less evil to use ice than to have the bntter oome from the churn white and soft. In churning, the dashers are so arranged as so go dowonward vithin a quarter of an inch of 
the bottom of the churn, and to rise above the cream in their upward stroke.

The temperature of the cream while being churned, should be kept below 65 deg.; for if at the close of the churning the buttermilk should be at that temperature or above it, the flavor and color of the butter will be injured. In cold weather, the temperature of

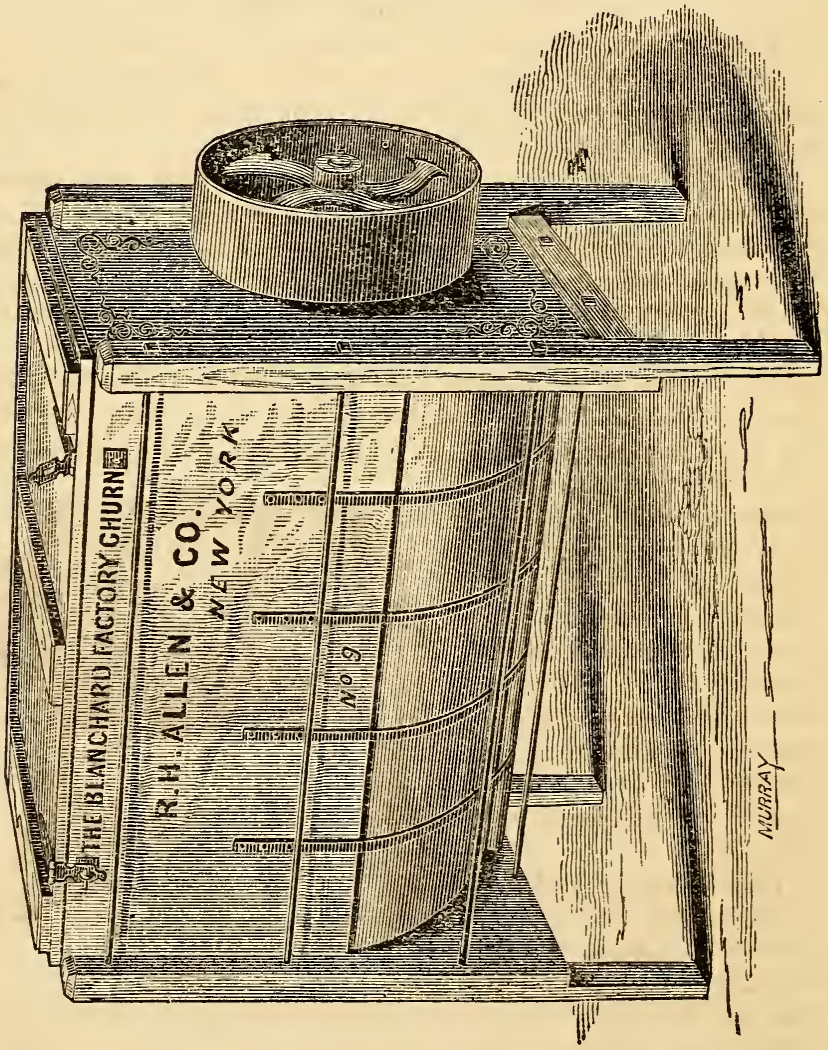

FiG. 22.

the cream, when ready for churning, is a little higher than in warm weather, about 62 deg. being considered the right point. Factorymen prefer that the churning 
should occupy on an average about forty-five minutes; a half-hour being the shortest space of time, and an hour the longest, that should be employed in tnis operation. When the butter begins to come, the churn is rinsed down with cold spring water. The butter should come of a firm or solid consistency and of a rich yellow color.

\section{OTHER FACTORY CHURNS.}

Recently the Messrs. Blancirards of Concord, N. H., have introduced a factory churn that has superior merits, and is coming rapidly into use. The illustration, Fig. 22, on page 100, shows its general form.

The dasher shaft is of iron, and upon the end which projects outside the churn, is an iron driving pully, which should make twenty-five or thirty revolutions per minute. The speed may be regulated according to the judgment of the operator. An ingenious arrangement allows the shaft to be withdrawn through the box near the driving pully, leaving the dasher free to be lifted ont as in their smaller churns. This gives the greatest possible facility for handling the butter. A glass is set in the cover, so that the progress of the churning can be seen, without stopping the motion of the dasher, or lifting the cover. In some factories the revolving barrel chum is used and gives satisfaction. I give an illustration of the form usually employed in Fig. 23.

The churning is sometimes done by horsepower. There are a variety of powers, but

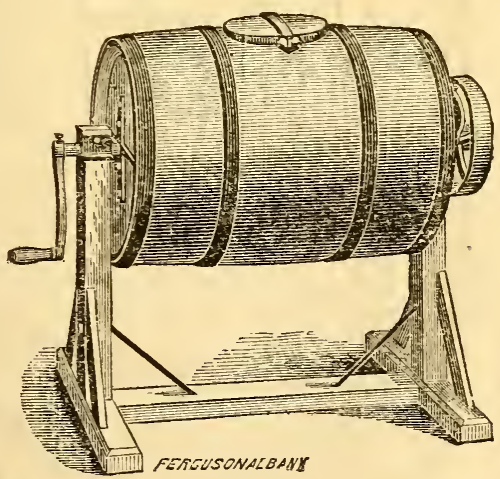

FIG. 23. that most commonly used at the old factories in Orange County is simply a large, circular platform or wooden wheel, built about an upright shaft, the end of which turns in a socket. The wheel sets upon an incline, so that the horse, by walking constantly on one side, keeps it in motion. At the upper end of the shaft, gearing is arranged 
so as to give motion to the churns. More recently a small engine in connection with the heating arrangement for the skim-cheese department has been used to supply power for driving the churns. I shall refer to these with illustrations in another place.

\section{EXPELLING THE BUTTERMILK AND SALTING.}

The bntter is now removed from the churns, and care is taken never to touch it more than is necessary with the hands. It is lifted with the ladle into elliptical wooden trays, and the buttermilk is rinsed out with cold spring water. In this proceeding the ladle is used lightly, while the water being turned over the butter is allowed to pass off at one end of the tray. This process is repeated two or three times, when nearly all the buttermilk will have been rinsed away.

Some use a sprinkler for washing the butter. The batch of butter, or the "churning," say of twenty to twenty-five pounds in weight, is laid upon the butterworker, and water applied from a sprinkler or small watering pot. It is provided with a rose nozzle so as to distribute the water over the mass in numberless small streams. The watering-pot is held with the left hand, and the butter worked with the right hand at the same time, by applying the lever, going rapidly over from one side of the mass to the other.

The butter being on the inclined slab or bed-piece of the butter-worker, the buttermilk flows off readily, and by a few movements of the lever the buttermilk is expelled. When the water flows from the mass without being discolored the process of washing is completed. The sprinkler should be of small size, or no larger than can be conveniently handled with the left hand in the manner above described. The water, falling in a spray over the whole surface of the butter, cools it and gives the proper degree of hardness for working with the lever, a point of considerable importance, espccially in hot weather. When the butter-milk has been expelled, the butter is ready for salting, and the butter-worker is used for incorporating the salt evenly through the mass. Salt is now added, and worked through the butter with the butter-worker, at the rate of 18 ounces for 22 pounds of butter. Great care is taken that the salt be pure, and of those brands that are 
known to be free from the chloride of calcium, as a trace of this impurity gives a bitter taste to the butter. For butter that is designed to be kept over for the winter markets, a little more salt is sometimes used, often as high as an ounce of salt to a pound of butter. Not unfrequently a teaspoonful of saltpeter and a tablespoonful of white sugar are added, at the last working, for 22 pounds of butter.

Considerable discussion has recently arisen about the use of saltpeter in butter, some holding that it cannot be healthful even though employed in small quantities, that it adds nothing to the flavor or quality of the butter, that it has no preserving properties, and hence should be banished from the dairy by all good butter-makers. Without entering upon an elaborate discussion of this question it will suffice, perhaps, to say that saltpeter has been used from time immemorial in curing meats, and of the thousands who thus annually employ it, I have yet to hear of a single authenticated case where it has proved injurious.

The butter-makers of Orange County claim that, by the use of saltpeter, butter will retain its flavor, and keep sound longer in hot weather than when it is not used. They say that many direct experiments have been made to test this point, and in every instance the samples of butter cured with saltpetre, kept sweet longer and were better saved than those samples where it was not used. For curing butter made in summer, therefore, the following mixture is often used, viz: For every 22 pounds of butter 16 ounces of salt, 1 teaspoonful of saltpetre, and a table-spoonful of the best powdered white sugar. In preparing this mixture, Ashton salt or best Onondaga factory filled, is crushed under a roller to free it from all lumps; it is then run through a sieve, and then saltpetre, after being reduced to a powder, is evenly mingled with the sugar through the salt.

In the matter of salt, however, the factories adapt the quantity to suit the taste of their customers, or for different markets. Of late years, light-salted butter sells best, and the rate of salting varies from one-half to threefourths of an ounce of salt to the pound of butter. The butter, after having been salted and worked, is allowed to stand until evening and is then worked a second time 
and packed. In hot weather, as soon as the butter is salted and worked over, it is taken to the pools and immersed in water, where it remains until evening, when it is taken out, worked over and packed. For this purpose a separate pool is provided, which is used only for butter ; it is called the "butter pool," and fresh spring water" constantly flows in and out of it, as in the pools for setting the milk.

\section{WORKING THE BUTTER.}

In working the butter, considerable skill and experience are required that the grain of the butter shall not be injured. The butter must have a peculiar firmness and fineness of texture and a wax-like appearance when fractured, which an improper handling, in expelling the buttermilk and working, will destroy. Care is taken, therefore, not to overwork it nor subject it to a grinding manipulation like tempering mortar, as this spoils the grain and renders the butter of a greasy or salve-like texture.

The butter is worked with butter-workers. The one

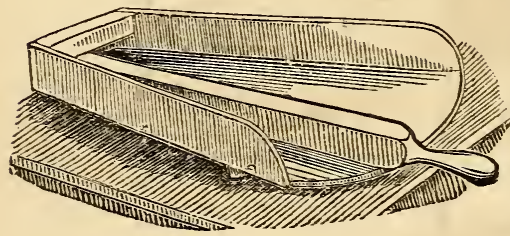
in most common use consists of an inclined slab standing upon legs, and with beveled sides about three inches high (see Fig. 24). The slab is four feet long by two feet FTG. 24. wide at the upper end and tapering down four inches at the lower end, where there is a cross-piece, with a slot for the reception of the end of the lever. There is also an opening at this end for the escape of the buttermilk into a pail below. The lever is made either with four or eight sides and the end fits loosely in the slot, so as to be worked in any direction. It is quite simple, but does good execution and is much liked at the butter factories.

The Champion Butter-Worker (Fig. 25) is a butter-worker, weigher and salt-crusher combined. The operation of this worker is on the same principle of a hand and ladle; while the scales are so nicely arranged that any one can do the weighing without lifting. This machine is furnished by Whitman \& Burreli, Little Falls, N. Y. 
CHAMPION BUITER-WORKER.

After the butter has been washed, a batch weighing 22 lbs. is laid upon the inclined slab, or bntter-worker, first described, and then spread out with the ladle. Pure Ashton or Onondaga salt, made fine by rolling, is now sprinkled over the mass and the lever applied, first be-

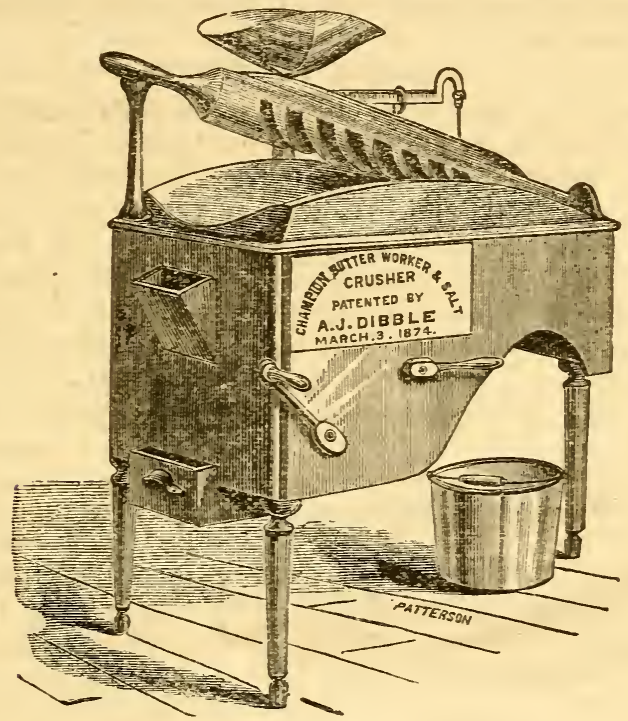

FIG. 25.

ginning at one side until the whole is gone ore:. Only a few manipulations of this kind are required to work in the salt and complete this part of the process.

As it is important that the buttermilk should be completely removed, this is facilitated during the working process by applying a slightly-dampened napkin to the surface, or by the nse of a damp sponge covered with a napkin for the purpose.

ADDITIONAL SUGGESTIONS IN WASHING, WORKING AND SALTING BUTTER.

Mr. S. E. Lewis of Oxford, N. Y., has some rery good suggestions in regard to treating the butter after churning: 
"When the butter comes," he says, "and as soon as the dash churns clean, take off the churn; do not gather the butter with the dasher in the churn (as is usually done); do not gather it at all, but have a hair sieve, which first wet in lot and then in cold water, so that the butter will not stick to it. Then have a piece of a board that will fit inside of the churn to hold the butter back; turn the buttermilk from the churn through the sieve. When the buttermilk is drained out, let the butter remain in the churn; then take your water, holding it up high as your head, and pour it upon the butter in a stream sufficiently large so that it will force its way through the butter; keep the stream moving about upon the butter. This will separate the little balls of butter; fill up the churn with water until what little buttermilk there was in the butter is diluted to that extent that there will be no necessity of changing the water, and the result will be that your butter is washed or the buttermilk all rinsed out of the butter without breaking, marring or injuring a single grain of the butter.

\section{WORKING IN THE SALT.}

"When it sufficiently hardens in the water, take it out for salting, using the ladle to get out most of it, then the sieve. Now comes the salting and working. For a butter-worker an inclined plane in the shape of the letter $\mathrm{A}$, with a round lever, is preferred. Spread the butter upon the worker, then put on half the quantity of salt you clesire to use, roll it in, then with a small, flat, wooden shovel, turn one-half of it over on to the top of the other half; put on half of the remaining salt, roll it back; do the other half in the same way, and then put on the balance of the salt; then work the salt in somewhat, taking particular care not to let the lever slip on the butter while working it. Always let the lever go on the butter in a rolling motion. If you allow the lever to slip on the butter, it will destroy the grain and make it look shiny. Set the butter away in a cool place at night; put it. on the worker; work it a little, then let it stand until morning, and work again just enough to be sure the streaks are out (the white streaks are parts that have not taken salt), then pack. The butter-worker should stand face to 
the light. The best butter bowls to use are the white oak butter tubs."

Mr. Lewis is the manager of a creamery, and he expresses the opinion that as much butter can be made on the plan of setting the milk deep as by shallow settings. He recommends that the cream of each milking should be churned by itself, or if the cream of different milkings is to be churned, the cream of such milkings should be mixed at least eight to ten hour's before churning. Enough milk should always be skimmed in with the cream to give the butter when it comes a clean, bright color.

\section{PACKING.}

The butter is packed in firkins, in half-firkins, and in Orange County pails. The pails are "return pails"that is, they are not sold with the butter, but are to be returned to the factory after the purchaser has taken out the butter. They hold about sixty pounds of butter, are of white oak, nicely made, and strongly hooped with heavy band-iron. They have movable covers that fit closely, and are fastened with wooden bolts or metallic clasps. The firkins are made of white oak, heavily hooped, and the sides neatly turned.

The greatest attention is paid to have the packages perfectly tight, 'so as not to permit the least leakage. White oak is regarded as the best material for packages, and the butter factories use no other. The firkins hold about 100 pounds each. The halt-firkin is simply the firkin sawed in two and provided with an oak head, which is nailcd on the top of the package after it is filled.

The firkin is prepared for use by soaking in cold water, after that in scalding water, and then again in cold water. It is then either filled with brine and soaked 24 hours or the inside is thoroughly rubbed with dry salt and left to stand for a short time, when it is considered ready for use.

In packing the butter it is pressed together as solidly as may be, and when the firkin is filled it is immediately headed up and a strong brine poured through a hole in the top head, to fill the intervening spaces. The orifice is then closed, and the firkin is set in a cool cellar until it is ready to be sent to market. When the half-firkin is filled, a dry cloth, cut so as to entirely cover the butter, 
is spread over it and covered with a thin layer of salt. The cover is then fastened on and the package is set away in a dry, cool place until it is taken to market.

The best wooden package I have ever seen is the Wescott Return Butter Pail, manufactured by Silsby Bros., Belmont, N. Y. It is made of the best kiln-dried white oak, matched and turned perfectly inside and outside. I give in Fig. 26 an illustration of this pail, and add the following sensible hints which the manufacturers send out with their packages:

"To neutralize the odor and sap of the wood, and to drive from the cells of the wood the air which taints the butter, the pails ought to be thoroughly soaked with hot brine made from the same kind of salt with which the butter is cured, and not used over and over again, until the bitter taste of the wood has destroyed the use of the brine, but thrown away after each pail is scalded. After the pail is thus prepared, pack the butter solidly, putting on the top of it a clean, white cloth, and cover the cloth with a layer of the same kind of salt, half an inch in thickness.

Each time your pails are returned from the city, scald and cleanse them thoroughly."

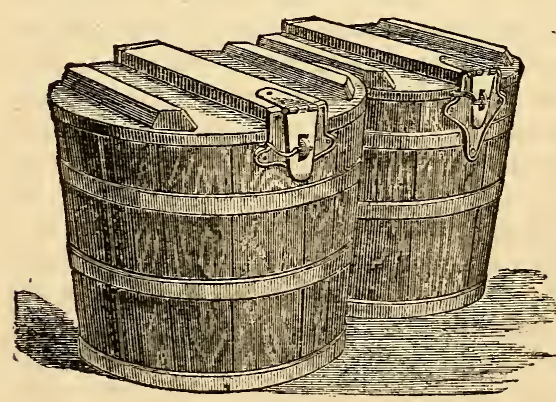

FIG. 26 .

Small return buttei pails similar in construction to "Wescots's Return Pail" and each holding five pounds have been used in sending "fancy butter" to market. These little packages, or tubs, are provided with a cover which fastens with a clasp. They are very neatly made of oak and hooped with brass or galvanized iron, which gives them a handsome appearance. They are, when filled, packed in cases, twelve packages in a case, in two tiers, one above another. A board is placed between the upper and lower tiers and is secured in the following manner : 
There is a cleat running round the box on the inside about the hight of the packages, so that when the flrst six packages are arranged in place the division-board goes down upon the cleat covering the lower packages, and upon this board the upper tier of packages is placed. The lid of the case is then brought down and fastened with a clasp, and the packages go safely to market without shaking or moving. The butter in each package is stamped with a mold, so as to leave the imprint of the maker's name under a rose.

Recently, Mr. Chunles H. White of White Station, Michigan, has invented a method for keeping butter sweet for long periods, which proves to be excellent and worthy of general adoption. His plan is to have tight and strongly hooped tubs of oak, with heads at both ends. The tubs are 14 inches in diameter at top and 9 inches at bottom, and about 16 inches high. Fig. 27 will illustrate their general form. A sack of white cotton is made to fit the tub for the reception of the butter. It is placed in the tub as it stands on the small end (Fig. 27), the sides of the sack being long enough to extend over the top of the tub.

The butter is packed firmly in this sack until within an inch and three-eighths of the top of the tub, when a circular piece of cloth is laid on the top of the butter, and the sides of the sack are brought over and nicely plaited down over the circular cover. A layer of fine salt is now laid on the top, the head is put in, and the hoops are driven so as to make a perfectly tight fit that will admit of no leakage. The tub is then turned upon the large head and the butter in the sack drops down upon the larger end, leaving a space between it and the sides and top of the tub, as will be seen by Fig. 28, representing a section of the tub filled with butter and standing on the large end. Strong brine is then poured into the tub at $a$, till it fills the intervening space $c c c c$ between the tub and the butter, when the hole is closed perfectly tight with a cork. The brine floats the butter so that it is completely surrounded with the liquid, and thus it is effectually excluded from the air. Butter packed in this way, and placed in a cool, clean, well-ventilated cellar, keeps sweet and sound for long periods, and will go to market in prime condition.

When the butter is to be used the tub is turned on the 
small end, the hoops are started, and the large head is taken off, when the butter may be lifted entirely out of the tub by taking hold of the ends of the sack. It may be placed upon a platter or large earthern dish, the cloth removed from the top, and the butter cut in desirable shapes for the table or for sale. If any portion remains or is not wanted for immediate use, it may be returned to the tub, and in this way it can be preserved for:future use.

Butter for the winter market is often packed in firkins holding from 60 to $80 \mathrm{lbs}$. The firkins are made strong

FIG. 27-Package for keeping Butter for long periods.

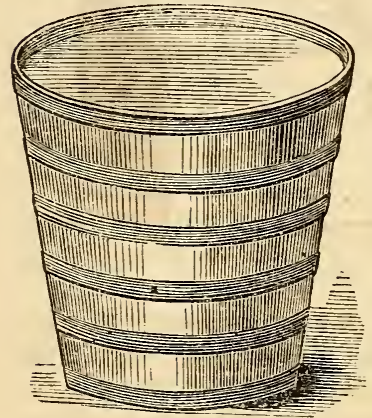

FIG. 27.
FIG. 28-Section of Package for keeping Butter for long periods.

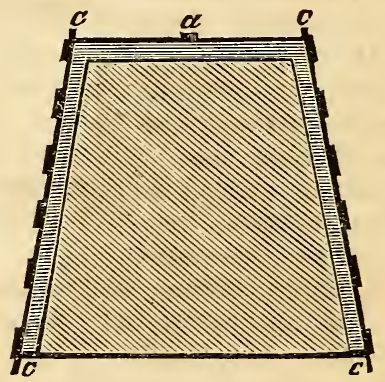

FIG. 28.

and tight, are provided with heads, and when filled are headed up and brine poured through a hole in the top head, so as to fill all intervening spaces. In packing butter for market, it is important to have a neat and wellmade package. If due attention has been given to the manufacture and to the packages, and if the butter has been preserved sweet and sound, there will be no trouble in marketing it at a good price.

\section{PACKAGE FOR BUTTER PRINTS.}

During the summer of $1874 \mathrm{I}$ was in Virginia and visited the butter factory of EDward J. Sirth, near Lincoln, Loudoun County. At this factory, which is on the pool system, the butter is accurately weighed in halfpound lumps and then pressed in a mold, receiving a neat stamp. The prints are oval in shape, about $2 \frac{1}{4}$ by $3 \frac{1}{2}$ inches and 2 inches thick, and after stamping, each print is wrapped in white muslin, the cloth being cut in small 
squares, the print laid upon it and the corners of the cloth coming up on the sides of the print. This gives it a very nice appearance.

The butter is made for the Washington Market and is shipped in boxes, having an ice chamber in the center. The boxes are 31 by $16 \frac{1}{2}$ inches and 15 inches deep. See Fig. 29. The ice chest is of tin, placed in the center of the box, and is $16 \frac{1}{2}$ by 5 inches, 15 inches deep. At the bottom there is a hole, which extends also through the box for the escape of water from the ice as it melts.

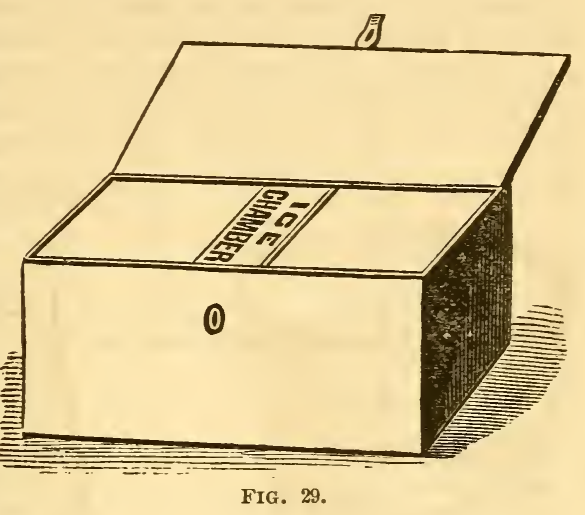

Movable shelves, with cleats on the edges, are fitted on each side of the ice chest, the one above the other, for holding the prints. The box holds 10 shelves, 5 on each side of the ice chamber, and the shelves, when in place, leave a space between each of $2 \frac{1}{8}$ inches, or just sufficient to clear the tops of the prints.

Each shelf holds 20 prints or 10 pounds of butter, and consequently, the box holds just 100 pounds. The whole package when filled, and the chamber packed and closed, weighs 224 pounds.

\section{CREAMERY FOR A SMALL NUMBER OF COWS.}

In the accompanying cut, Fig. 30, I give an illustration of the Union Creamery in Madison County, New York, which is designed to take the milk from 150 to 200 cows. I visited this factory during the latter part of 1874 . Skimmed cheese is not made at the establishment, the skimmed milk beingtaken away by patrons and fed to swine and calves. The milk is kept longer in the pools than at creameries where skim-cheese is made in connection with butter manufacture. 
The building is in the shape of an $\mathrm{L}$, the main structure being 36 feet long by 16 feet broad. Une side sets against a bank, the earth being excavated or cut down below the surface from three to four feet. The pool, P.R. as will be seen from the cut, is $13 \times 21$ feet and is reached from the delivery window by the passage way or walk P. W., which is three feet wide. Stout planks are thrown

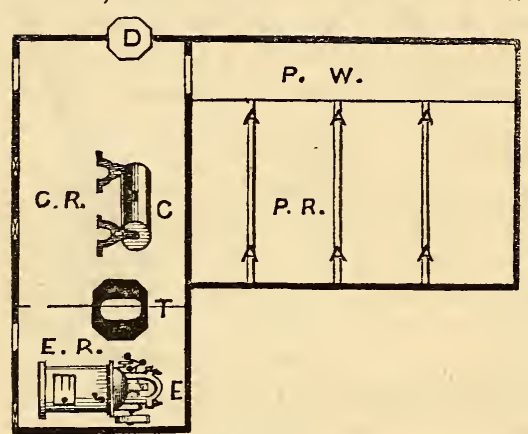

FIG. 30 . across the pool at such points as are desired A A. A A., in order to facilitate the handling of the milk. The principal objection to this arrangement is, that the temperature of the milk in the pool can not be kept uniform ; for as the warm milk is delivered morning and evening, the water in the pool must be raised in temperature more or less, according to the quantity of warm milk added. We think it would have been better to have separated the pool into parts or divisions:

The churn-room, C. R., is $12 \times 18$ feet, and in the wall between it and the engine-room there is a large wooden tank, T, about $2 \frac{1}{2}$ to 3 feet high, with hinged covers, one in each room, so that the water may be supplied in both apartmeuts from the same tank. The water in the tank is heated from the boiler, E, in the engine-room, E. R., by means of pipes. This arrangement is very convenient. $\mathrm{D}$ is the delivery window and $\mathrm{C}$ is the churn.

\section{TREATMIENT OF THE MILK.}

The milk, as it is received, is placed in pails, eight inches in diameter by twenty inches long, and these are immediately plunged in the water. The water in the pool is about eighteen inches deep and its temperature at the spring is from 49 to 50 degrees Fahr. About 650 pails are required for setting the milk, which is held in the pools from three to four days before skimming. The 
milk is kept this length of time in the pool nuder the impression that more cream will be obtained than when the milk sets only 48 hours.

The manufacturer, Mr. J. S. DART, in experimenting with milk set at different lengths of time finds that when it has set 48 hours and is then skimmed and the pails returned to the pool, enough more cream will rise to pay for keeping in the pool for the time named. After the cream is removed the skimmed milk goes to the patrons of the factory and is used for feeding calves and hogs.

\section{CHURNING AND WASHING.}

The churn used is the revolving barrel chmrn known as the Philadelphia. The churn holds 90 gallons, but only about 70 gallons of cream can be churned at a time. The cream is left in the pool until it becomes slightly acid, when from 50 to 60 gallons are placed in the churn, the temperature of the cream in summer being about 58 Fahr. and in cool weather from 60 to 62 Fahr. The churn is regulated so as to make about 40 revolutions in a minute, and so soon as the cream begins to swell the vent is opened to let out the gas. The churning occupies from an hour to an hour and one-half, when the butter should come in grains from the size of a wheat kernel to that of a pea. The buttermilk is then drawn off and the butter washed in the churn by pouring in cold water and allowing it to revolve for about one minute.

\section{WORKING AND SALTING.}

The butter now goes into the salting tray, which is 38 inches long by 20 inches broad and 6 inches high. This is placed on the floor under the churn, and the churn being opened the butter falls into the tray. For the New York market, three-fourths of an ounce of salt to the pound of butter is used, but for the home market one ounce of salt is employed. The Ashton salt is preferred, and it is worked through the butter as evenly as possible, a thin paddle, having a blade 7 inches long by five wide, being used for the purpose. The butter is worked as little as possible in salting, and is then thrown loosely into tubs which are immediately immersed in the pool and remain there until next day, when the butter is taken out and worked on a butter-worker. When the 
working is completed, as above described, the butter is packed in "return butter pails" and goes to New York City, the price paid at the factory being within two cents per pound of the best quotations for fancy butter in the city.

\section{RESULTS.}

During the month of Jine, 25 pounds of milk on an average yielded one pound of butter. In Angust, 24 pounds of milk made a pound of butter, and during September and up to the day of our visit the average was a pound of butter from 23 pounds of milk. The factory is a new one, costing about one thousand dollars

\section{PLAN FOR A LARGE CREAMERY.}

Factories on the pool system are arranged in different ways, but one of the most complete and convenient is shown in the accompanying figure. The plan was drawn on a large scale by H. Cooley Greene, Esq., of Pennsylvania, and was used in the illustration of his address before the American Dairymen's Association in 1872. In the cut, Fig. 31, the size is very much reduced, but will be readily understood from the description of the parts. Upright, $40 \times 60$ feet; wings, each $24 \times 40$; ground descends toward the right and rear ; AA receiving room, $3 \frac{1}{2}$ feet above the floor of main building; P P P pool in three apartments, separated by 3 -inch plank, which are tied by a cross plank 10 inches wide. The milk room opens by sliding doors to the vat room, VR which is open to press-room and churn-room, C. B is walking beam with arms for attaching 16 churns, motive power in engine house. $\mathrm{E} \mathrm{D}$ is curing room for new made cheese ; $\mathrm{S}$ store-room ; $\mathrm{O}$ office ; W wash-room ; 5 , sink on castors ; $V$ veranda, with pail racks; $p$ p steam jets for scalding pails, churns, \&c.; t t water tanks, lower one for cold and upper one for hot water, with faucets in either room; $T$ trap for elevating butter from cellar, which is under left wing; a a a are traps to drains for slops ; I is drain for whey and buttermilk. All liquids carried beneath the floor. O $\mathrm{P}$ open platform for airing churns, \&c. Second floor devoted to curing-rooms, separated by rolling doors at each side. 
THE CREAM VAT.

Among the new features of this factory is the cream vat. It is constructed on the same principle as the regular cheese vat, and holds about 200 gallons. Into this

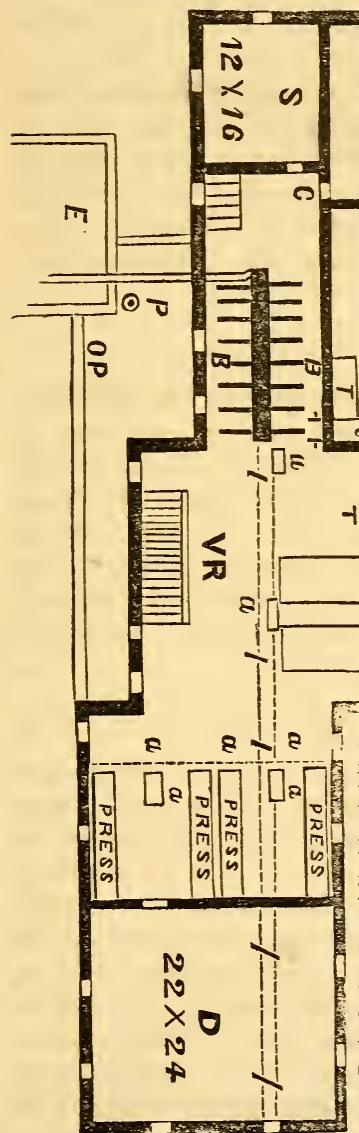

FIG. 31 . the cream is poured, thoroughly mixed and warmed or cooled, as required, by the steam and water connections. In describing the advantage of this vat Mr. GreEne says : "The process of skimming milk at most

lar to an ordinary skimmer handle, and contains nearly a quart. It is immersed in the milk, the cream flowing into it, and is thus dipped off. This operation is repeated till there is no cream seen upon the surface of the milk. 
The process is, of course, somewhat imperfect, as there is some milk taken with the cream. The milk is now turned into the vat for curds, and the pails are carried to the wash-room. The cream is poured into the cream vat through a strainer of finely-perforated tin, which not only thoroughly mixes it, but separates from it any flies or other foreign substances which one would not like to see in his butter. In this vat the cream remains till next day, when it is churned. Meantime, if the weather be cold, steam is applied to slowly warm the cream. If the weather be very warm, it is surrounded with cold water, that it may neither become too warm nor too sour. It is covered with a close-fitting frame, upon which is stretched a piece of muslin to exclude dust, heat and flies. In most creameries cream is kept in pails and set into water, but in the absence of the cream-vat there is no adequate means for warming the cream when too cold.

Its adrantages are:-First, Cheapness. It costs less than pails of the same capacity. Second, Economy of labor and time in handling cream. Third, It enables one to control the temperature of his cream more perfectly, and to give it uniformity of character. Fourth, It admits of straining the cream conveniently, while sweet and thin, and keeping it neatly thereafter."

\section{VENTILATED CARRYING CANS.}

There are quite a number of patterns of carrying cans, all very similar in construction to that made by the Iron Clad Can Co., New York City, which is one of the strongest and best in use.

Milk cans should have a ventilating cover. One of the best arrangements of the kind is a recent invention by Messrs. Dunlap \& Bissowetr, of Jericho, $\nabla$ t. It consists in a rentilating chamber, on the under-side of the can cover, about 4 inches in diameter and $2 \frac{1}{2}$ inches deep, and having a gauze wire cover which can easily be removed for cleaning, \&c. In the center of the chamber is the tube passing through the cover. Holes are cut on the rim of the chamber. By this arrangement the ventilation of the milk is secured while being carted from the farm to the factory, and all slopping avoided.

Wickoff's Ventilated Milk CAN is furnished by 
Whitman \& Burrele, Little Falls, N. Y. The nature of this improvement consists in the construction of the can with a cover, that will allow the free escape of the heat and animal odor of the milk, while the slopping and injurious agitation are prevented; which is attained by the formation of one or more air-chambers and rent in the cover. The operation is as follows: If the can is filled, or supplied with milk, say to dotted line I, the air in the chamber $\mathrm{H}$ becomes compressed, and this prevents the corer from sinking, and also prerents the milk from injurious agitation in its transit from the yard to the point of delivery;

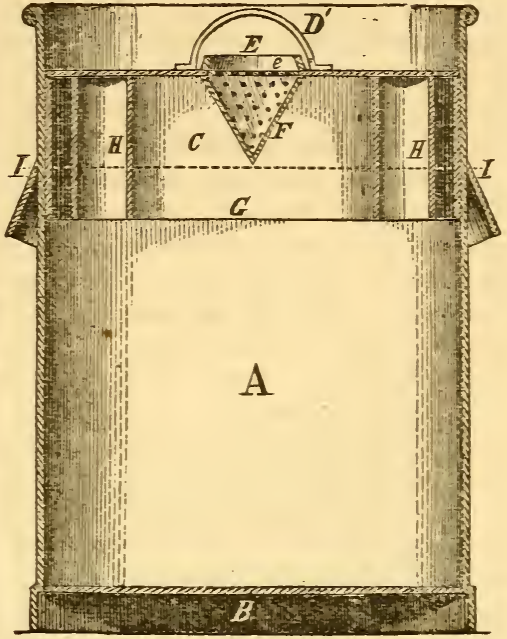

FIG. 32. and the vent $\mathrm{E}$ admits of the free escape of heat and animal odor, while the slopping of milk is prevented during its transit in the can.

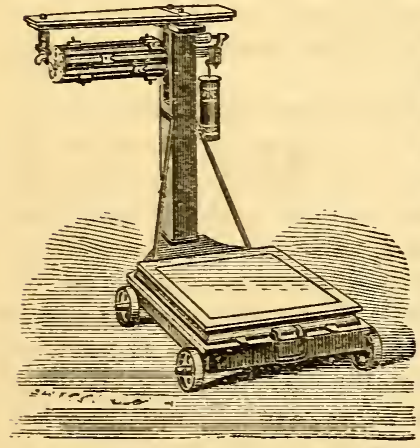

FIG. 33.

SCALES.

The most convenient factory scales are those recently invented by EDward F. Joxes, of the Jones Scale Works, Binghamton, N. Y. By an ingenious arrangement of the revolving bars and slides, the milk of several patrous can be weighed without dumping the milk at each weighing. These scales are very accurate, substantial, and not liable to get out of order. The cut, Fig. 33, grives an illustration of one. 
MEANS EMPLOYED FOR DETECTING DILUTED MILK.

The most unpleasant feature of the factory system appears when dishonest patrons attempt to rob the association by the delivery of watered milk. 'The laws of New York are very severe on persons found guilty of this misdemeanor, punishing them with heavy fines and imprisonment. The factory manager keeps watch over the milk as it is delivered, setting aside small quantities from time to time for observation and experiment with the hydrometer. Each factory is also provided with a set of small glass tubes, upon which numbers corresponding with the names of the patrons are pasted, As milk is delivered, a small sample is placed in the different

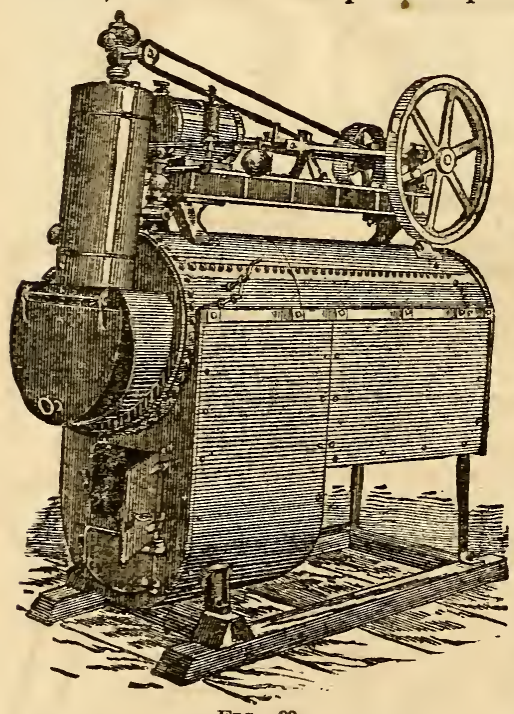
tubes corresponding with the name of the patron, and set aside. If the milk is not all right, the hydrometer and these samples give warning; the milk is then subjected to a more careful test, by the use of the cream gauges and per cent. glass.

Although there may be considerable variation in the specific gravity of milk from different cows, it has been found that when the milk of several cows is mingled together, and when the FIG. 33. milk of different herds of a neighborhood is compared, there is but little difference in the specific gravity of the several samples.

These tests have been effectual in bringing offenders to justice, and with the very strict law on the subject, but little trouble is now had on account of adulterated milk.

BOILER AND ENGINE.

Where considerable quantities of cream are to be 
churned and the skimmed milk is to be manufactured into skim-cheese, a boiler and engine will be found most convenient and in the end the cheapest. We give in the cuts Nos. 33, 34, 35, 36 and 37, illustrations of several of these which have been approved and are in use at the butter factories.

In Fig. 33 on page 118, we have a representation of boiler and engine manufactured by Joxes, FAULKNER \& Co., Utica, N. Y., which is largely in use.

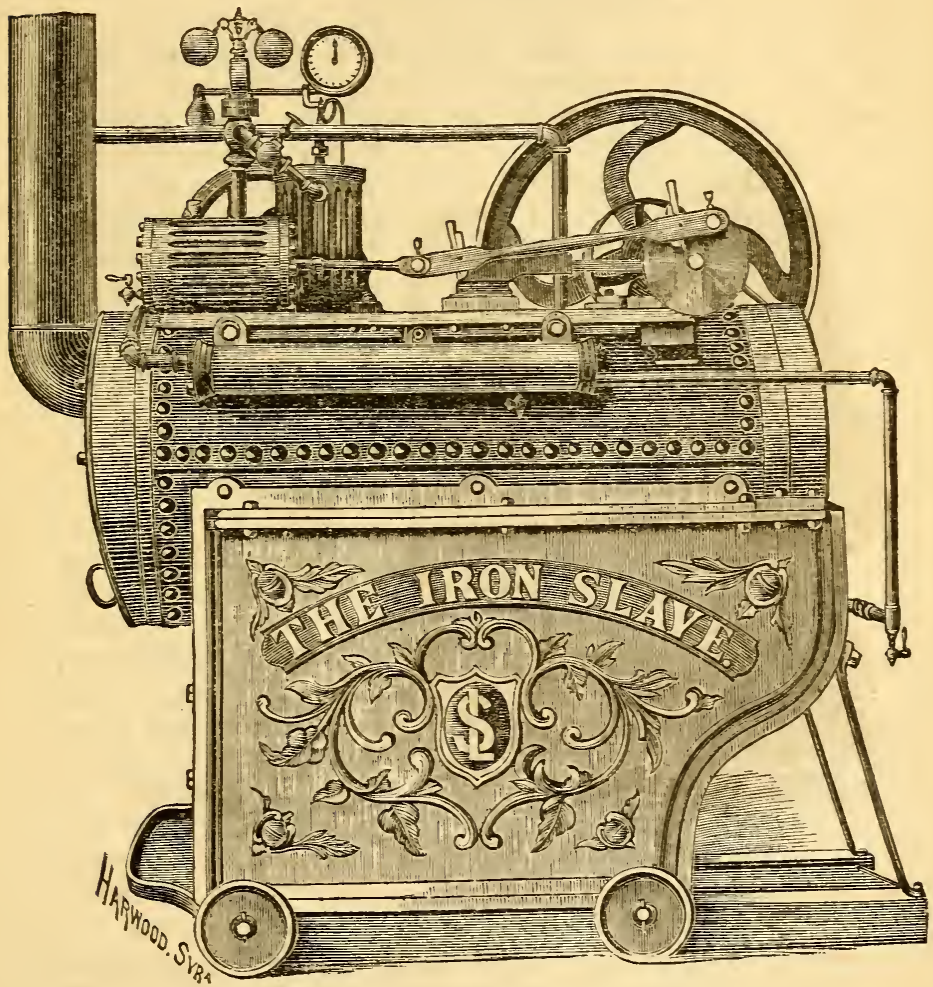

FIG. 34.

THE IRON SLAVE.

In Fig. 34 we have a cut of the portable steam 
boiler and engine furnished by Chas. Millar \& Son, Utica, N. Y.

ANOTHER PORTABLE BOILER.

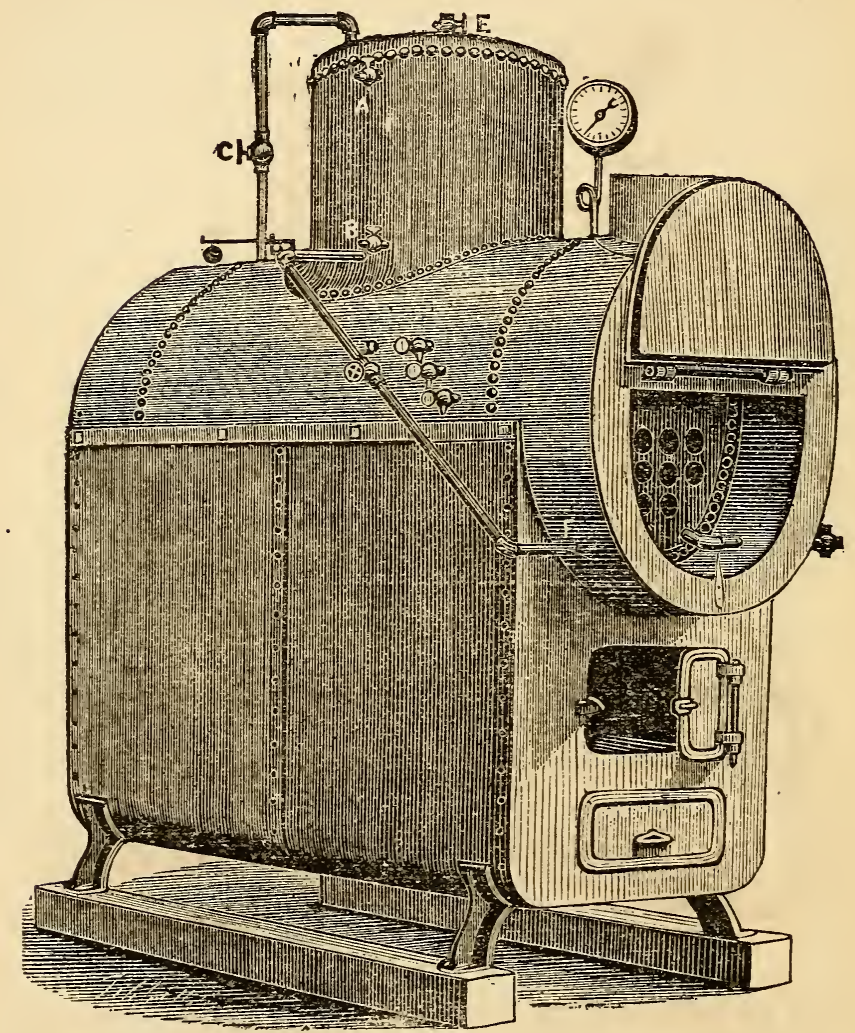

FIG. 35.

H. H. Roe \& Co., of Madison, Ohio, furnish a horizontal return flue tubular boiler which is shown in Fig. 35.

The same House also furnish engines adapted to these boilers. 
THE EAGLE STEAMER AND CALDRON.

This apparatus is manufactured by E. E. SiLL, of Rochester, N. Y., and is a steam generator and jacketed caldron combined. It can be employed both as a gen-

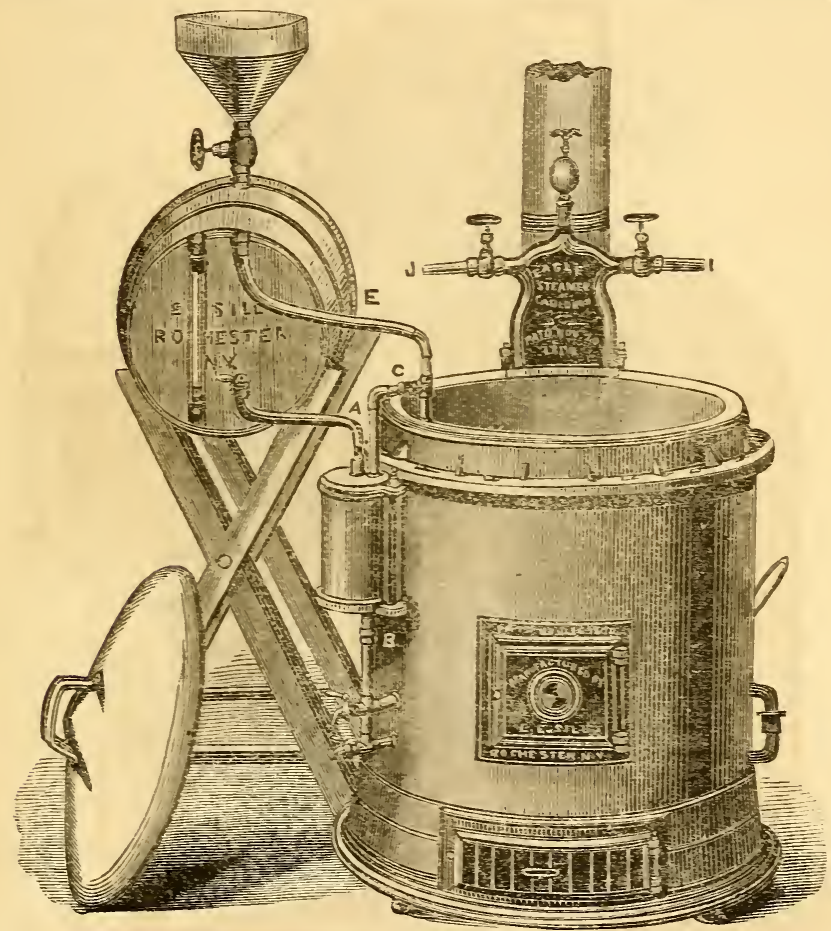

FIG. $3 \%$

erator of steam and an open caldron at the same time, or as a generator or caldron, and no detachment of parts is required to change from one to the other. This apparatus is designed especially for cooking food for stock, and is admirably adapted to the purpose. The cut, Fig. 36 , shows its general form.

THE ANDERSON BOILER.

Whitacax \& Burrell, of Little Falls, N. Y., are 
manufacturers of Axdenson's Patent Boiler and Tanks which they have introduced largely in factories and farm dairies. 'They furnish in connection with it, KIPP's new engines; the boiler and engine are represented ir Fig. 37.

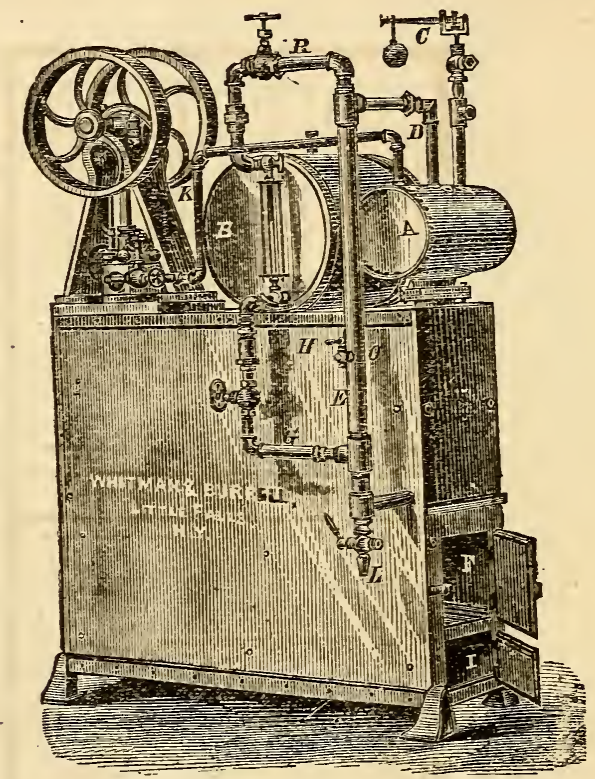

FIG. 37 .

PLAN FOR A BUTTER FACTORY OR CHEESE FACTORY COMBINED.

In concluding our remarks on creameries where deep setting is practiced we introduce the subjoined cut, Fig. 38 , showing ground plan of a butter factory erected by Gardser B. Weers, of Syracuse, N. Y. Referring to the ground plan, Fig. 38, it will be seen that in the arrangement the factory is quite as well adapted to cheese making alone, as to butter and skim-cheese manufacture. The adrantage of such an arrangement is that the factory may be turned at once to the making of whole-milk cheese or to butter and skim-cheese, as one or the other system may happen to be most profitable. 
The ground plan explains itself and needs no description. The upper story of the factory is for a cheesecuring room and may be divided off for other purposes as well if desired. It is regarded by many as a conrenient butter factory as adapted to the "pail and pool system."

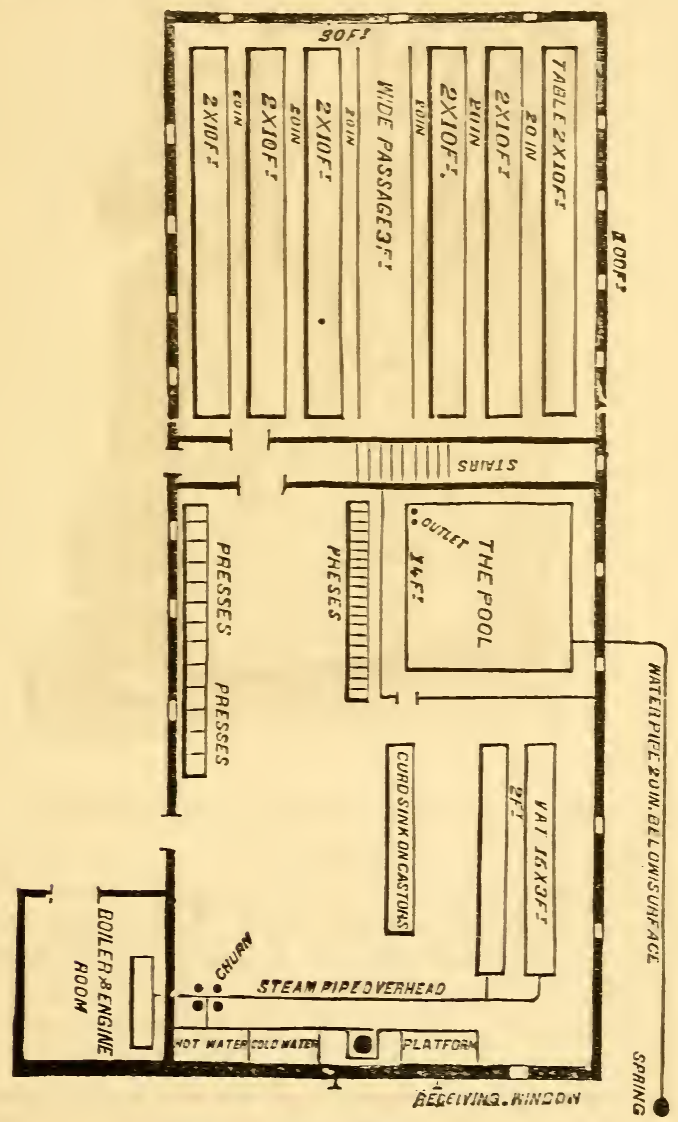

इTG. 38 


\section{CREAMERY PRACTICE-LARGE PANS SYSTEM.}

For farm dairies where cold spring water is convenient and plentiful, where only cheap dairy structures can be afforded, the large pan system presents many advantages. The pans, as is well known, are each made of a suitable size to take the entire mess of milk of the dairy at one milking, whether the number of cows be 5 , or 100 , and four pans complete the set or all that will be required to hold the milk until it is 36 hours old. It is claimed by some that if the temperature of the milk be kept at about 60 deg. Fahr. that the atmosphere of the milkroom may be allowed to go several degrees above that temperature without injury, and indeed, with advantage in the rising of the cream. Be this as it may, much better results are obtained in an ordinary milk-room by setting the milk in large pans surrounded with cold water than by the old plan in small pans standing in the open air.

In Franklin County, N. Y., where the large pan system has been largely introduced for factories, the average quantity of milk required for a pound of butter, taking the season together, has been from $20 \frac{3}{4}$ to $25 \frac{1}{4}$ pounds. Thus the Keeler factory of Franklin County reported in 1871 a pound of butter from $2070-100$ of milk; the Union fastory, a pound of butter from $24 \frac{1}{2}$ pounds of milk; the Cold Spring, a pound of butter from 22.31 pounds milk; the Berry, 25.10 pounds ; Moria, 23.12 ; and the Bailey Spring 22.55 pounds of milk for a pounds of butter. In 1872 a pound of butter was made at the Union, from 23.3 pounds milk; Barley Spring, 22.61 pounds; Berry, 24.26 pounds; Moria, 22.37 pound. In 1873 the quantity required for a pound of butter was at the Union, 23.9 pounds milk; Barley Spring, 24.28; Cold Spring, 22.47. These are generally better averages than are made under the process of the "pail and pool," but it must be remarked that under the latter plan it is not desired to take all the butter from 
the milk, as the skimmed milk is to be turned into skimmed cheese. But where the large pan system is practiced the skimmed milk is usually employed for feeding domestic animals, and all the butter is taken out that can be.

The first invention of the large pans was made by the late Dr. Jexnings, of Fredonia, N. Y., and consisted simply of a shallow vat of tin placed in a wooden vat with space between the two for the reception of cold water. I tested this pan on its first introduction, and fiom experiments then made was highly pleased with the principle. Various improvements have been made in the construction of the pans so as to make them more efficient and convenient, and I gire illustrations of some of the most approved patterns now before the public. Usually, one surface foot of pan bottom will be sufficient for two cows; so that any one may calculate pretty accurately what will be needed for his dairy. The sides of the pan are about five inches high. The way to use them is to put one milking of the entire dairy into one pan, adjusting the faucet in the supply pipe so as to use just water enough to extract the animal heat from the milk, and keep it at the desired temperature while the cream is rising-say from 60 to $62 \mathrm{deg}$. At the time the fourth pan is wanted for use, the first will be ready to skim; then stop the water from running into the pan that a sufficient quantity of water may run out while the milk is skimmed, and run off to enable the milk-maid to clean the pan.

\section{THE JEWETT PAN.}

As given in the engraving, Fig. 39, one of the series of pans, is represented as broken away to show the internal arrangement. These pans are provided with a space, between their top and bottom walls. Within this space are a number of compartments communicating with each other at alternate ends, in such a manner as to form one continuous channel, zigzag in its course, having an inlet at through which warm or cold water, as needed, is received; such water, after flowing through the tortuous channel formed by the partitions, being discharged at the outlet. A fancet is shown through which all the water in the chammel can be drawn off. 
When the cream has raised and has been skimmed, the milk is then run off through the pipe $d$, which communicates with the main discharge pipe, $\mathrm{F}$, which may be placed under the floor or not, as circumstances will permit; or if desired the milk can be conveyed in movable

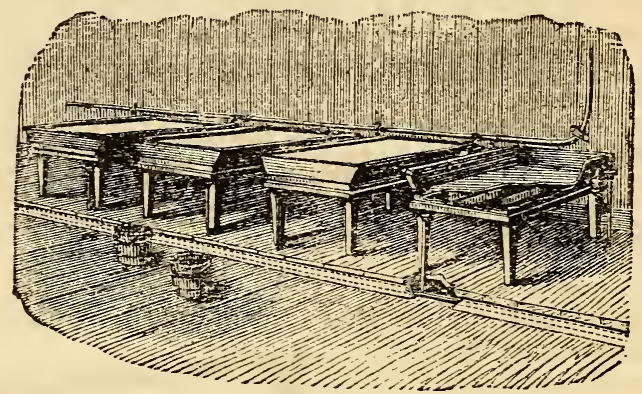

FIG. 39.

horizontal pipes from the pans into an adjoining room on the same floor. The pipe seen attached to the side of the room and above the row of pans is the source of supply from which water is conducted to the base of the pans. For cooling, the water is received from a spring or reservoir; but for warming, from boilers or other appropriate apparatus.

These pans are manufactured by L. R. Townsend, of Maloue, N. Y.

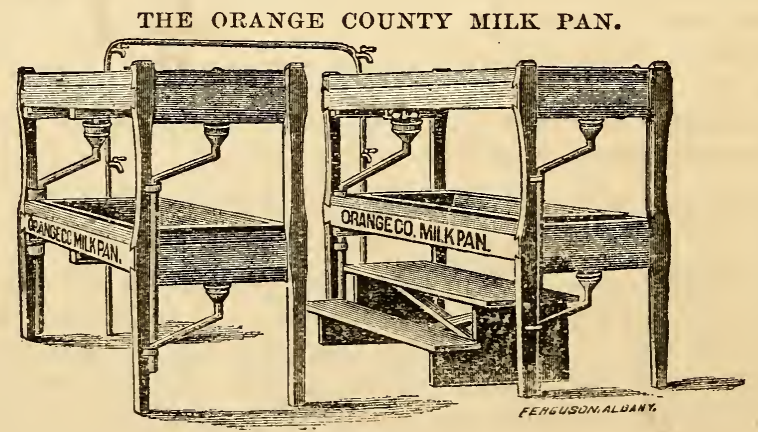

FIG. 40.

This is manufactured by the Orange County Milk Pan Company, of Franklin, Delaware County, and is highly 
approved by many. They are arranged in four single, or two double racks, whichever best suit the size of the dairy-loom. I give a cut of the double rack arrangement in Fig. 40.

When arranged in double racks, the upper pan is reached by means of a moveable platform, which is kept under the rack, and when wanted is drawn out. By use of the double rack a set for thirty cows can be used in a room $8 \times 10$.

It has an arrangement for cooling with ice, having space at each end of the Pan in the Pat, where ice may be stored, and, as it melts, the water passes off down through the Regulator Pipe.

\section{COWLES' MILK PAN.}

Is the invention of Setu F. Cowles of Coventry, Vt, and furmished by $\mathrm{W}$. R. Colby, of Stanstead, Canada. The distinguished feature of this arrangement, see Fig. 41 , is the manner in which the milk is removed from the pan. It is the only pan that empties over the top and thereby avoids the use of corks, which sometimes prove troublesome in getting sour and

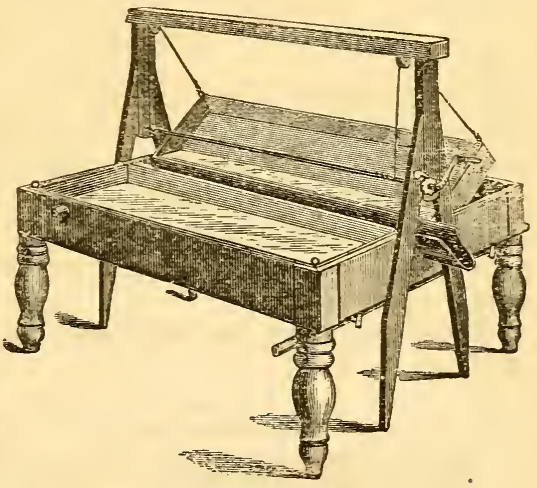

FIG. 41. allowing the milk to leak.

PLAN OF BUTTER FACTORY ON THE LARGE PAN, OR "SHALLOW SETTING" SYSTEM.

The factories on the shallow setting system are usually less elaborate than those where pools and pails are in use. In Fig. 42 is an illustration of the general features found in these establishments. For the milk of 100 cows only four pans would be required. The pans occupy more space than on the pool system, but less water is needed to do the same work.

The plan of the factory, Fig. 42 will be readily under- 
stood. The main building is $60 \times 30$ feet and the wing $10 \times 14$ feet. W is the work-room, $14 \times 22$ feet, and $\mathrm{S}$ the sink; $\mathrm{P}$ is the churn-room, $8 \times 14$ feet, and $\mathrm{C}$ the churm; $\mathrm{E}$ is the engine-room, 10x14 feet, and $\mathrm{B}$ the boiler and engine. There are 12 pans, set-opposite to each other, six on a side, which will accommodate the milk of 300 cows. The pans are $130 \times 57$ inches, and are set not quite two feet apart and with one end nearly or quite against the wall, as represented in Fig. 1. $\mathrm{T}$ is a tank for sour

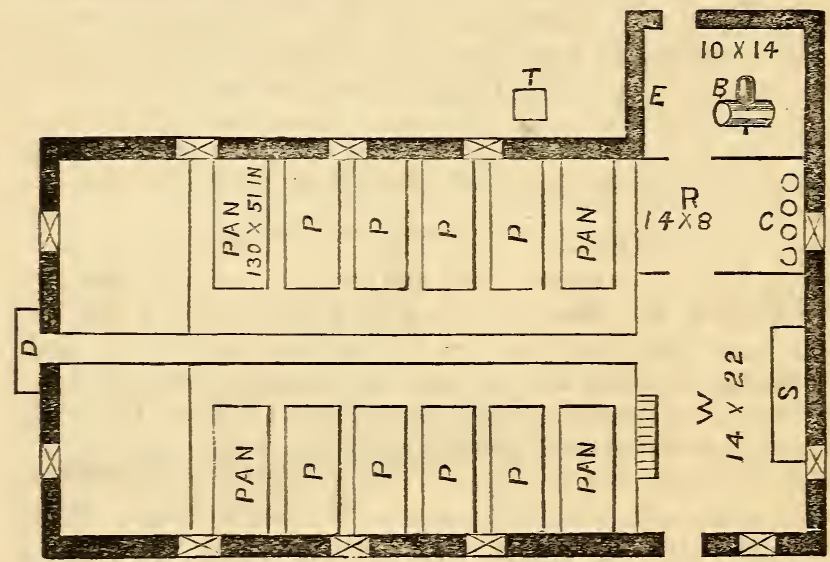

FIG. 42.

milk; $D$ delivery window. There is a track for a hand car running through the center of the building between the pans. Underneath the structure is the butter cellar. In this arrangement there is no provision for making "skim-cheese," thongh of conrse when it is desired the building may be extended in length, and thus room made for the manufacturing department.

\section{FACTORY BUTTER BOX.}

Mr. Lrwis of Chenango Co., suggests that in case there is not a very good butter room in a factory, a long box, tight at the bottom, with a cover to it, should be made. Place a rack in the bottom, some three inches from the bottom of the box. Then in warm weather put your butter in the box, and have water running into one end of the box and out of the other, under the butter. 
This will keep it cool and hard until it can be worked and packed.

MAKLYG PREMIUM BUTTER ON THE SHALLOW SETTING STSTEM.

At the Central New York Fair, Utica, in 1874, the first premium on creamery butter was awarded to the Cold Spring Creamery, East Hamilton, Madison County, N. Y. About the middle of September I risited the Cold Spring factory and obtained from the manufacturer the process of manufacturing at this factory, where shallow setting is practiced and it may be of interest in this connection. The factory is a small one, $20 \times 30$ feet, taking the milk of only 90 cows. There are nine patrons and milk is delivered morniug and evening, the most distant patron living about one-half mile from the factory.

\section{PLAN OF SETTING THE MILK.}

The Jewett pans are used at the Cold Spring Creamery. The size of the pans is $11 \times 4$ feet, six inches deep, and four pans complete the set. The pans are of the ordinary size for 150 cows, but the manager of the Cold Spring fictory thinks they are noue too large for 100 cows. The milk is set four inches deep in the pans.

The milk during summer is held in the pans until it is 24 to 36 hours old, and is generally allowed to sour. When the milk begins to lopper at the bottom and the cream is wrinkled it is skimmed. The pans stand with one end butted against the wall, and at this end are the pipes for admitting the flow of water under the milk. The temperature of the water in the spring is 56 degrees, and it is desired to keep the milk at about 60 degrees while the cream is rising. In the spring and fatl, or during cool weather, a coal stove in the room regulates the temperature so that the milk stanis very uniformly at 60 degrees.

CHURING.

The churning is done every morning, Sundars excepted, the Saturday's cream being churned Saturday night. The dish churn is used, barrel and a half size, and it is operated by horse power. Mr. Holves think no churn equal to the dash for making a nice grained butter. During the hottest weather the cream in the churn is tempered to $5 \mathrm{~s}$ deg., but at the time of our visit, the 
17 th of September, the temperature of the cream when the churns are started is 60 deg. About an hour is occupied in churning and when the butter begins to come the motion is deadened or made slower and four quarts of cold spring water are added to each churn. Enough water is added so as to raise the liquid mass to cover the dash to prevent it striking the cream. Then just so soon as the butter is formed the churns are detached from the power and the butter gathered by hand.

The buttermilk is now drained off and the butter thrown into a large tub with cold spring water, where it is washed by working it gently with the ladle. Washing in two witers thoroughly expels the buttermilk, when it is immediately salted at the rate of three-quarters of an ounce of salt to the pound of butter.

\section{THE SALT WEIGHER.}

Mr. Howmes has a very handy implement for butter makers, which may be denominated the "butter and salt scales." It is simply a pair of scales so arranged that by placing the butter in a bowl on a standard and by adding salt to the dish on the end of the scale yard until the scales are balanced, you get the exact quantity of salt required for the lump of butter. It is arranged so that the scales may be set for salting at the rate of from a quarter ounce to $1 \frac{1}{2}$ ounces of salt to the pound of butter. . It is a simple and cheap affair, and should be in the hands of every butter maker, as it saves time and trouble in weighing and calculating the amount of salt for a given weight of butter.

The salt is worked through the butter while in the washing tub, the ladle being used for that purpose, when the butter is removed to the cooling vat or where the vessel holding it may be surrounded with cold spring water and it remains there until next morning, when it is thrown upon the butter worker and worked over and then goes to the packages. The butter is put up in Wescott return butter pails and goes to New York City, and the price received at the factory is two cents less per pound than the highest quotatious for fancy butter in that city.

BUTTER FROM A GIVEN QUANTITY OF MILK.

During the summer, under this system as above des. cribed, 100 pounds of milk yield four pounds of butter; 
but as the season advances a pound of butter is obtained from a less quantity of milk. At the time of our visit the ratio was one pound of butter from 23 of milk.

\section{CREAMERY REPORTS.}

The following reports from creameries where skimcheese is made in commection with butter manufacture, and where only butter is made will be of interest in this connection. These reports show the advantages of the respective systems :

REPORT OF 1872 AND 18\%3.-BUTTER AND SKIM-CHEESE.

\begin{tabular}{|c|c|c|c|c|c|c|c|}
\hline CREAMERIES. & 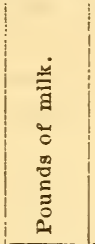 & $\begin{array}{l}\dot{0} \\
0 \\
0 \\
0 \\
0 \\
01 \\
0 \\
\infty \\
0 \\
\Xi \\
0 \\
0\end{array}$ & 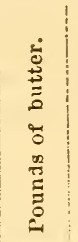 & 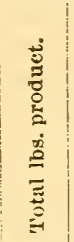 & 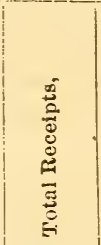 & 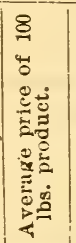 & 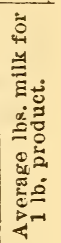 \\
\hline 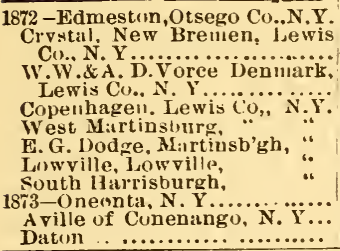 & $\begin{array}{r}2,592,589 \\
707,32 \\
705,705 \\
623,786 \\
1,213,815 \\
732,602 \\
1,831,373 \\
582,163 \\
576,453 \\
2,017,199 \\
1,562,538 \\
\end{array}$ & $\begin{array}{r}181,528 \\
68,692 \\
69.583 \\
59.900 \\
125.054 \\
15.158 \\
19.738 \\
60 ., 621 \\
84,784 \\
16,736 \\
130,329 \\
\end{array}$ & $\begin{array}{r}873 \\
1,954 \\
1,107 \\
2,75 \\
2.063 \\
2,912 \\
1.121 \\
20,418 \\
530.04 \\
26,374 \\
\end{array}$ & $\begin{array}{r}71,537 \\
61,007 \\
127,785 \\
77.521 \\
198,550 \\
61,742 \\
\end{array}$ & \begin{tabular}{|r}
$\$ 35,08914$ \\
8,24279 \\
9.09158 \\
$7,5358 \pi$ \\
15.64758 \\
9,91076 \\
$24,3378 \pi$ \\
7,91613
\end{tabular} & $\begin{array}{ll}\$ 14 & 81 \\
11 & 85 \\
12 & 71 \\
12 & 25 \\
12 & 24 \\
12 & 78 \\
12 & 25 \\
12 & 83\end{array}$ & $\begin{array}{r}9.87 \\
10.22 \\
9.96 \\
9.45 \\
9.7 \\
9.43\end{array}$ \\
\hline
\end{tabular}

REPORT OF 18:3.-BUTTER.

STATEMENT OF SIX BUTTER FACTORIES USING THE LARGE MILK PANS FOIR THE SEASON OF 1873, AND THEIR POST OFFICE ADDRESS.

Cold Spring Factory, Malone, Franklin (Jo.. N. Y., W $\mathrm{m}$, ],yttie, Proprietor........... Bailey Spring Factory. Ch:ı teaukua, Frankïin Co.. N. Y. Ira Benmett, l'roprietor... Union Factory. Bangor, Frankliu Co., $\mathfrak{N} . \dddot{Y}$, Stock Co. R. Roice, Eec'r.

Belmont Factory, Belmont, Franklin Co., N. Y. Kirby \& Adums, Proprieturs... ......

Cold Spring Factory. Last Hamilton. Madison Co. N. Y. Üsher Bris., Proprietors.

Vondburre Fartory. IV undburne, snllivan Co., N. Y. Wm. Bernard, Proprictor,..

\begin{tabular}{|c|c|c|c|}
\hline 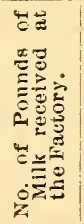 & 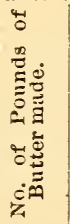 & 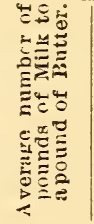 & 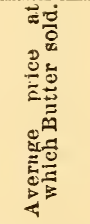 \\
\hline 764,009 & $3:, 011$ & $224 i-100$ & $3353-100$ \\
\hline 676.214 & 27.817 & $2428-100$ & $3326-100$ \\
\hline 42,695 & 17,765 & $23 \mathrm{i}-1 \mathrm{CO}$ & 33 \\
\hline 472.768 & 21.142 & $2236-100$ & $501 / 3$ \\
\hline $2 \mathrm{~S} 2,3 \mathrm{SO}$ & 11,466 & $236-10$ & $3327-100$ \\
\hline 139606 & 5,731 & $242-5$ & 34 \\
\hline $2.759,68$ & & $23_{11}^{75}$ & 3) $\begin{array}{c}81622 \\
118462\end{array}$ \\
\hline
\end{tabular}

Average Number.. 
THE DAKE SYSTEM FOR IMPROTIYG FARM AND DAIRY BUTTER.

About eighteen years ago a plan for manufacturing cheese on a large scale was inaugurated in Ohio. Its general features were as follows:-The milk was converted into curds at the farm dairies in the usual manner, and then each dairyman took the fresh curds daily to a central factory, where they were weighed and credited at a certain rate per pound. The central factory then mingled the different curds together, salting and pressing them into cheese of uniform size and weight, when they went to the curing room, and from thence to the markets. This plan was adopted previous to the establishment of our present factory system, and high hopes were entertained as to the nltimate success of the morement. The practical working, however, proved defective. The curds furnished by the different dairymen were not alike, but varied in texture and quality, some being too soft, others too hard scalded, to say nothing of those more or less sour and otherwise imperfect. Under these conditions the fermentation of the cheese during the curing process was not uniform through the mass, and the result of the whole procedure was that an inferior product was turned ont, which of course went at low price. Meanwhile the present factory system began to spread throughout New York and to take root in Ohio, and the manufacture of cheese from curds collected together, as referred to, was abandoned for the more rational plan of that now in general use.

A somewhat similar plan to the above has been recently inagurated in Wisconsin and other parts of the West for the manufacture of butter. The milk is set for cream at the farm dairies, and after being churned is taken to the factory, where it is weighed and each mess properly credited at a certain price per pound, and the different parcels are then mingled together, to go through the several manipulations of working, salting and packing.

\section{THE DAKE PROCESS.}

The originator of this system is Dariel W. DAKE of Beloit, Wis., and his butter factory and its machinery are represented to be entirely different fiom anything heretofore known in this line of the dairy. As soon as the 
butter arrives fresh from the farmers' churns, four or five hundred to one thousand pounds are put in a vat, which is about eight feet long br two feet broad and eight inches deep. Here the butter is cut with a wooden ladle into small pieces, and moderately cold water poured orer the mass until covered. A wooden hoe is then taken and the butter hoed from one end of the vat to the other twice, by which time the water has tempered it to a consistency for easy working throngh the machines. These machines are described in the Milwaukee Journal of Commerce as follows:

The first machine used is simply a wire screen covering the bottom of a hopper, and through which the butter is rapidly forced by a hand lever or crank. A thousand pounds of butter can be run through this machine in from three to four minutes, and it comes out of an exact consistency-hard lumps all cut up and thoroughly prepared for the next process. If the butter is white, as in winter, it is given a little color, then salted, and afterwards put twice through machine number two. This second machine thoroughly and evenly distributes. the salt and the color, if any is used, and at the same time extracts all the brine and buttermilk. Br this process it is said that two men can prepare, handle, salt. color and pack away in tubs from three to five thonsand pounds per dar. Again, it is claimed that the butter prepared comes out uniform in color and texture, althongh it is made from the cream of fifty different herts and on as many different farms. And it is claimed that Eastern butter dealers who hare handled the Dake butter for an entire season, speak of it as a decided improrement over farm dairy butter as usually made at the West.

\section{PHILOSOPHY OF BUTTER IIAIIG AID BUTTER KEEPISG.}

\section{CAUSES THAT DELAT BUTTER FROM COMIT.}

Difficulty is sometimes experienced late in the fall on accomt of the churning occupyiug an unreasonable time. Some of the causes which delay the butter from coming 
are as follows: The milk may have been kept at uneven temperatures and the cream may have been held too long from souring. Sour and sweet cream may have been mixed and not properly stirred so as to be of the same condition as to acidity throughout.

The cream from farrow cows may have been mixed with cream from those that are not farrow. The milk may have stood too long before skimming. The cream may not have been sufficiently warmed, or the cows may have lacked salt while being fed on dry food. One or more cows may have been indisposed and the milk in consequence be imperfect or feverish. Some of the cows may be near the point of drying off and the milk is not good, and should not have been saved, and especially should not have been added to the milk of others which is good. Poor keep, neglect and cruel treatment of cows also have their influence on the quality of cream and affect its churning.

In the first place milk, when set aside for cream, should be kept at a pretty uniform temperature, say at about 60 deg. Fahr. If milk be constantly changing from one temperature to another, according to the variable change of the atmosphere, or if cream be raised on one portion of the milk at one temperature and on another portion of the milk at a different temperature, the churning is liable to be more or less affected. Again, the temperature of the cream, when it goes to the churn, should be regulated by an accurate thermometer, say at about $58 \mathrm{deg}$. to 60 deg. Fahr. It is important to have an accurate thermometer. Some instruments are worthless on account of inperfect graduation. I have seen thermometers hanging side by side in the same temperature showing a variation of from $s \mathrm{deg}$. to $10 \mathrm{deg}$. It is needless, perhaps, to say that a thermometer varying $10 \mathrm{deg}$. from the true graduation would be likely to cause trouble in churning, if the cream was tempered according to the instrument, because cream that goes to the churn too cold or too hot will not readily be converted into butter ; and when the butter does come it will, from too long churning, be of inferior quality. Again, if cream is allowed to get too sour there is liable to be trouble in churning. If the cream be taken off from milk at different times, or several messes added together to make a churn- 
ing, the cream should be well stirred in the cream pot at every addition, in order to mingle the messes thoroughly. Then, when the mass has acquired a slight acid condition, it should go to the churn.

Cream is sometimes refractory in churning on account of the bad condition of water with which the cows are supplied. 'This is apt to occur in hot weather, when water is scanty and cows are compelled to slake thirst from stagnant pools or firom sloughs and mud holes, where the water is filthy. I have known cases to occur where great difficulty was had in making butter on account of bad water, but which was removed by changing the pasture or giving them a range where good, sweet running water was obtained. In one instance coming under my observation, there was great trouble in churning during hot weather, while the cows were drinking from filthy pools; but on the dairyman's sinking a well and pumping water for his herd the trouble ceased altogether. In order to test the matter and see if the bad water was the cause of the dificulty, he withheld the well water from his cows, and the trouble with the cream returned.

I have seen cases where the cream would not readily churn when the cows were raced from the pasture and overdriven by dogs during hot weather. The milk at such times becomes feverish, and the cream undergoes a change which is prejudicial to the butter forming properly. If attention is given to the kind treatment of cows, if they have an abundance of nutritious feed, plenty of good, clean water, regularly salted, and the milk kept at a uniform temperature of about $60 \mathrm{deg}$. while the cream is rising-in fine, if the cream goes to the churn at the right temperature, the butter ought to come in the churn in from thirty to forty-five minutes, according as the floats are rotated. We do not believe in very quick churning-from a half to three-quarters of an hour is soon enough for the making of extra fine butter.

\section{CHURNING THE MILK.}

It is claimed by some, that churning the whole milk makes more and better butter than to set the milk and churn the cream. A good many experiments have been made in Germany, to test this question, and Peterser says if the process be properly conducted, butter made 
by churning the whole milk is of infinitely finer flavor than that made from churning cream alone, and this he affirms is the universal verdict whenever both systems have met with fair trial. He gives the average amount of milk required to make a pound of butter by both systems, thus showing that when the cream is churned alone it takes from 16 to 17 litres of milk to make a pound of butter, but when the whole milk is churned about 14 litres is suffiicient. A litre is a little over $1 \frac{3}{4}$ pints.

In 1869, Hr. James ZoLler of Oswegatchie, N. Y., was requested by a committee of the New York State Agricultural Society, to make experiments to test the quantity of milk required to make a pound of butter when only the cream was churned, as compared with the whole milk churning, and he gave as the result, the following: When the milk was strained in pans and the cream churned, 208 quarts of milk yielded $17 \frac{1}{2}$ pounds of butter ready for packing, and when the whole milk was churned the same quantity of milk made $19 \frac{1}{4}$ pounds of butter ready for packing, being a gain of about 10 per cent. over churning the cream. The milk was allowed to sour but not loppered when it was churned. A temperature of about 65 degrees is said to be the best for chnrniug whole milk if sweet, but the usual temperature employed is lower, from 60 to 63 degrees Fahr.

In the Dutch process the milk is put into deep jars in a cool place, each mess or portion milked at one time being kept separate. As soon as there is the least appearance of acidity, the whole is placed in an upright churn to be churned. When the butter begins to form in small kernels, the contents of the churn are emptied into a sieve that lets the buttermilk pass through; the butter is then formed into a mass. In the Scotch method the milk is allowed to stand undisturbed until it has soured and become loppered, and when it has arrived at this state it is fit to be chumed. It is put in the churn and agitated a few minutes merely to break the coagulum, and is then brought to a temperature of about 70 degrees and churned. In some sections the milk is churned sweet, either a few hours after milking, or the night's and morning's mess of milk mingled together and churned in the afternoon. It is so much more work to churn the 
milk than the cream that whole milk churning is not very widely practiced.

\section{THE BEST TEMPERATURE FOI CHURNING CREAM}

Is from 55 degrees to 60 degrees Fahr. Some years ago a series of carefully conducted experiments were made in Scotland, to determine the temperature best adapted for making butter, the crean being churned at Valrious temperatures, ranging from 57 to 70 degrees. When the cream was churned at 57 degrees and not higher than 60 degrees, the butter was of the very best quality, rich, firm and well tasted. From 62 degrees to 70 legrees the butter was more soft and spongy, and at the highest temperature it was decidedly inferior in every respect to butter made in churning at the lower temperatures. The experimenters thence concluded that the best temperature to commence the operation of churning is abont 55 degrees, and at no time in the operation ought it to exceed 65 degrees, while on the contrary if at any time the cream should be under 50 degrees, the labor will be much increased without any proportionate advantage being obtained. This agrees with the American practice. It must be observed however that

\section{THE AGITATION OF THE CREAM IN CHURNING}

should be regular, neither too quick nor too slow. If the agitation is too quick the butter will make and unmake itself before the churner is aware of it, as too rapid motion induces fermentation, which, when it has reached a certain point, is entirely destructive of anything like the possibility of making even moderately good or welltasted butter. If, on the other hand, the motion be too slow, the agitators in the churn fail to produce the desired separation of the component parts of the cream, and the consequence is that after a good deal of time spent in lazy action, the churner is just as far from his butter as he was at the beginning of his labors.

WHAT SHOULD BE THE APPEARANCE OF THE BUTTER.

It has been well remarked by Mr. Stephens that when butter is properly churned, both as to time and temperature, it becomes firm with very little working, and is tenacious, but its most desirable state is that of waxy, when it is easily molded in any shape, and may be drawn 
out a considerable length without breaking. It is only in this state that butter possesses that rich, nutty flavor and smell which impart so high a degree of pleasure in eating it and which enhances its value manifold.

It is not always necessary to taste butter in judging of it; the smooth, unctuous feel in rubbing a little between the finger and thumb, expresses at once its richness of quality; the nutty smell indicates a similar taste, and the bright, glistening, cream-colored surface shows its high state of cleanliness.

\section{WASHING THE BUTTER.}

In the matter of washing and salting butter, Prof. S. W. Johnson of Sheffield Scientific School, Yale College, has made some very useful remarks, which we quote. He says : "To prepare butter for keeping, without danger of rancidity and loss of its agreeable flavor, great pains is needful to remove the buttermilk as completely as possible. 'This is very imperfectly accomplished by simply working or kneading. As the analyses before quoted show, salting removes but little besides water and small quantities of sugar. Caseine, which appears to spoil the butter for keeping, is scarcely diminished by these means. Washing with water is indispensable for its removal. In Holland and parts of Holstein, it is the custom to mix a considerable amount of water with the cream in churning. The butter is thus washed as it "comes." In Holland it is usual to wash the butter copiously with water besides. The finished article is more remarkable for its keeping qualities than for fineness of flavor when new. The Holstein butter, which is made without washing, has at first a more delicious aroma, but appears not to keep so well as washed butter. Swedish butter made by Gussander's method, in which the cream rises completely in 24 hours, the milk being maintained at a temperature of 60 degrees to 70 degrees Fahr. is when prepared without water, the sweetest of all. If, however, it is to be kept a length of time, it must be thoroughly washed before salting."

\section{PHILOSOPHY OF SALTING.}

"Immediately after churning the mass consists of a mixture of butter, with more or less cream. In case very rich cream (from milk kept warm) is employed, as nuch 
as one-third of the mass may be cream. The process of working completes the union of the still unadhering fat globules and has, besides, the object of removing the buttermilk as much as possihle. The buttermilk - the presence of which is objectionable in new butter by impairing the taste, and which speedily occasions rancidity in butter that is kept-cannot be removed by working alone. Washing, as already described, aids materially in disposing of the buttermilk, but there is a limit to its use, since if applied too copiously, the flaror of the butter is impaired. After working and washing there remains in the butter a quantity of buttermilk or water which must be removed if the butter is to admit of preservation for any considerable time. To accomplish this as far as possible, salting is employed. The best butter makers, after kneading out the buttermilk as far as possible, avoiding too much working so as not to injure the consistency or "grain" of the butter, mix with it abont three per cent of salt, which is worked in layers and then left standing for from 12 to 24 hours. At the expiration of this time the butter is again worked, and still another interval of standing, with a subsequent working, is allowed in case the butter is intended for long keeping. Finally, when put down, additional salt (one-half per cent.) is mixed at the time of packing in the tubs or crocks. The action of salt is osmotic. It attracts water from the buttermilk that it comes in contact with, and also takes up the milk sugar. It effects thus a partial separation of the constituents of buttermilk. At the same time it penetrates the latter and converts it into strong brine, which renders decomposition and rancidity difficult or impossible. Sugar has the same effect as salt, but is more costly and no better in any respect. Independent of its effect as a condiment salt has two distinct offices to serve in butter making, viz:-First, to remove buttermilk as far as possible from the pores of the butter, and, second, to render innocuous what cannot be thus extracted."

\section{CONCERNING THE MANNER OF WORKING BUTTER.}

When the grain of butter is injured the butter spreads like grease, and the more it, resembles grease the more is the grain injured. Good butter that has a perfect grain will not stick to the knife that cuts it. Butter that has 
no grain is brittle, and when broken presents a jagged surface and will not spread with that smooth, waxy appearance belonging to good butter. Care, therefore, should be taken not to spoil the grain by over working. In working butter the hands should not come in direct contact with the butter. Gather it together with a wooden butter ladle in the tray or butter bowl, turn off the buttermilk and wash with fresh spring water. Gash it around the whole circumference, making charnels lowest at either end, so that the buttermilk can readily run off. Do not grind it down against the tray, after the manner of tempering mortar, for in this way you will be likely to injure the grain. It is not well to attempt to work out all the buttermilk at once. But very little manipulation is required in washing out the buttermilk; then salt with pure fine Ashton or Onandaga salt and set aside in a cool place for twelve hours, during which time the action of the salt will liberate more of the buttermilk. Then work a second time either with the ladle or butter-worker, using precautions not to overwork or grind the butter by rubbing down against the tray, or slab if on a butter worker, and then the butter is ready for packing.

\section{CONCERNING BUTTER AND HOW TO IREEP IT.}

We need to know much more than we do about the proper preservation of many kinds of food, but especially of butter, which so easily deteriorates from a luxury into a state intolerable for human consumption.

I condense an account of several preserving processes that have been adopted in different countries for butter preservation, giving simply the main features of each.

\section{IN GIRARD'S METHOD}

the butter requires to be well worked, so as to extract from it all the milky particles, and when this is satisfactorily done the butter is spread out and a quantity of brandy or alchohol is poured over it, or is then kneaded together or worked up so as to effectually mix the two substances together. It is now made up into balls and these are wrapped in paper which has been previous'y steeped in brandy or alchohol spirit. This is afterwaru folded in another paper which will exclude the air as 
much as possible. For long sea voyages these packages are recommended to be packed in air-tight packages.

\section{BELIN'S PROCESS}

is first to beat up the butter between two linen cloths within three days after it is chmrned, in order to remove the whey or other matter which might cause rankness of flavor. The butter is now enveloped in paper prepared for the purpose by being coated with albumen made from the white of eggs. For every egg whose white is beaten up, about fitteen and a half grains of chloride of sodium (common salt), and half that quantity of salt of niter (saltpeter) is dissolved in this albumen, but the niter need not be used except the butter shows signs of rancidity. The paper, however, is not to be considered ready until it has been, before and after its preparation, subjected to a great heat by means of a hot smoothing-iron, or some other contrivance. For long preservation, the rolls are to be kept in a dry place, especially if the weather is hot.

\section{REDWOOD'S PROCESS}

consists chiefly in covering the butter with paraffin.

\section{BRINING BUTTER.}

Butter is often effectually preserved from the summer to the winter time by mixing it with salt and by merely inclosing hmps of it in canvass wrappers and putting them in jars containing a quantity of brine. The brine does not enter into the substance of the butter or render it in any way disagreeable. In the preparation of brine for butter, it is best to heat the brine scalding hot, skimming it, and then allowing it to cool and settle, pouring off the clear, cold brine, which is then fit for use.

\section{PRESERVING BUTTER IN FRANCE.}

In France the butter is often melted down and purified with honey, sixty grammes of honey to each kilogramme of butter. If these are carefully mixed, a very superior flavor is said to be obtained. Another method is to take one part sugar, one part niter and two parts salt, and reduce them by grinding to a fine powder. Two ounces of this mixture are kneaded into about two and a quarter pounds of butter. 


\section{SUGAR AND SALTPETER METHOD.}

These substances are regarded by many old and experienced butter makers as important aids in the preservation of butter. I have referred particularly to these preservatives, naming the proportions to be used as thought best by Orange County dairymen. I now present other mixtures: To ten ounces fine salt add two ounces saltpeter and two ounces best brown sugar. The different ingredients are to be evenly mingled together, and an ounce of this mixture nsed for every pound weight of butter and well worked in. Butter so treated, if closepacked and kept in a cool, well-ventilated place, will, it is said, keep sound for several years.

\section{ANOTHER RULE}

is, to mix one ounce of finely-powdered white sugar with one ounce of saltpeter and two ounces of large-grained English salt, and, after incorporating them well together, one ounce of the mixture is used to every pound of butter. The mixture must be well worked into the butter, which is then closely packed in clean earthen ware jars or crocks. These are then set aside and kept in a very cool place, and the butter, it is asserted, will remain in good condition for years, and has borne a voyage to the East Indies and still been serviceable. Butter thus packed, it is recommended, should stand untouched for two or three weeks after being packed, or it will taste rather unpalatable; but after that time it is said to acquire a fine, marrowy flavor.

\section{RESTORING RANCID BUTTER.}

Rancidity is caused by the presence of butyric acid, and such butter should be well washed with good, new milk, in which substance the acid is freely soluble. After this treatment it is to be washed with cold spring water.

\section{ANOTHER PLAN}

is to beat up a quarter of a pound of good, fresh lime in a pail of water, and after allowing it to stand for an hour, nntil the impurities have settled, pour off the clear portion and wash the rancid butter in that.

When the cream has been long kept before churning, when the ntensils have been unclean, or when the provender of the cows has been in bad condition, it not unfre- 
quently happens that the butter is found to have acquired a most disagreeable flavor. This mupleasant taste and smell is caused by an acid, and it is customary in some places to put a few drams of some acid-neutralizing alkali to every three pounds of butter; sometimes half a pint of vinegar is added to each gallon of cream for the same purpose.

\section{PACKING ROLL BUTTER FOR MARKET.}

Late fall and winter butter sometimes sells best in rolls. The trouble with roll butter, however, is that it often is not properly packed, and from lack of knowledge in this particular the butter assumes a ragged or untidy appearance, and in consequence sells at a low price. If roll butter could be sent to market in perfect form, it would not unfrequently command from two to five cents per pound more than when packed in firkins.

The Montreal produce dealers give the following instructions to dairymen concerning the packing of roll butter for that market, and the suggestions may be of service to dairymen in other sections when a considerable quantity of roll butter is to be prepared for shipping. They say:- "Use none but the very best barrels, and be sure that they are not burnt or dirty inside. The end intended for the head should be turned down, then take out the bottom head and cut a piece of fine white muslin the size of the head and place it on the bottom of the head of the barrel-which will be the head when opened. Commence to pack the finest and smallest rolls first, taking care to pack each roll on its smallest end. Be careful and select rolls that will pack snug, so there will be no space for the rolls to shake about; continue packing in this way until the barrel is almost full, then shake the barrel well to settle the rolls, and then fill it as snug as possible. In packing the last layer pack the rolls on their ends, if possible, but if there is not room it will not matter if they are packed on their sides, if they will pack sung and fill the barrel full. The great object is to have the rolls packed close and tight, so that they wil not shake about and break.

"Each roll must be wrapped in a piece of white muslin or cheese capping, and it should be large enough to cover the roll entirely. The muslin must be soaked in strong 
brine before using and must be put on the roll wet. It is impossible to send rolls to market in good order without wrapping them in muslin, and no matter what the muslin may cost it will more than pay the cost in the increased price the rolls thus packed will bring. Before heading the barrel, pour on two quarts of strong pickle; cover the last layer with a piece of muslin the same as that put on the head, drive down the hoops well and secure with nails. Then turn the barrel over two or three times so as to let the brine work in between the rolls; mark the top in plain letters, 'Roll Butter,' also the gross weight, tare of the barrel, and the address of the party to whom you send it, and the initials of the shipper. Rolls should be made oblong in shape and not weigh over 2 to 4 pounds."

PACKING ROLl, BUTTER IN JARS, PREPARING BRINE, ETC.

To three gallons of brine strong enough to bear an egg add a quarter of a pound of nice white sugar and one tablespoonful of saltpeter. Boil the brine, and when it is cold strain carefully. Make your butter into rolls, and wrap each roll separately in a clean, white muslin cloth, tying up with a string. Pack a large jar full, weight the butter down, and pour over the brine until all is submerged. This will keep really good butter perfectly sweet and fresh for a whole year. Be careful not to put upon ice butter that you wish to keep for any length of time. In summer, when the heat will not admit of butter being made into rolls, pack closely in small jars, and using the same brine, allow it to cover the butter to the depth of at least four inches. This excludes the air and answers very nearly as well as the first method suggested.

\section{ROLL BUTTER IN TIN CASES.}

Roll butter is sometimes sent to market in tin cases, or in small cylinders, each of the size suitable to receive the roll and opening in the center, thus allowing the butter to be easily removed. These cases preserve the form of the roll so that it arrives in market in as perfect condition as when it left the dairy. The cases are placed in a box, a number together, when shipped to market, and after the butter is removed the cases are returned to the butter maker. This is a nice way for marketing roll butter, which often commands fancy prices on account of its nice appearance. 
THE METALTC BUTTER PACKAGE.

Metalic packages have been used for a long time by foreign shippers in sending butter to warm climates, and with complete success. But it is only quite recently that an effort has been made to introduce their use among butter manufacturers. A common fault of wooden butter packages is that they are too loosely made and do not exclude the air from the butter. It is useless to try and keep butter sound, however well it may be made, unless proper attention be given to the packages and the packing. Soft and resinous woods rnake poor packages, as a flavor from the wood is apt to be imparted to the butter. The large demand for packages has nearly exhansted in the dairy districts the kinds of timber which ear be safely. used for butter, and as a result very much butter that might otherwise be good is injured; causing loss to both producer and shipper. Again, the absorption of moisture from the butter by wooden packages leaves the surfaces dry and exposed to the air, and causes the rancid taste so common to butter that has been held in wood for any length of time. But there is another oljection which has been urged against wooden packages, and this is the question of soakage, which has long vexed both buyer and seller. These objections would be obviated by the use of a suitable metalic package, and the ingenuity of inventors is now being exercised in this direction.

THE ENAMELED PACKAGE.

In the subjoined cut, Fig. 43 , we have the form of an enameled package invented by J. C. Tilton, of Pittsburgh, Pa.

It is made of malleable iron and the inside enameled with porcelain, the lid being fastened in a peculiar way so as to be perfectly tight. It is provided with

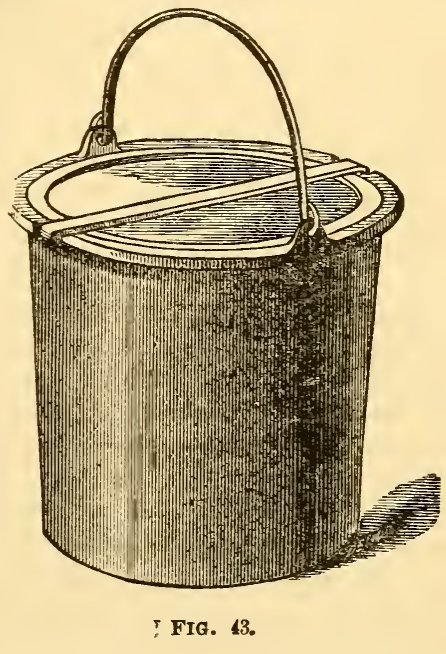


a bail to facilitate handling, and can be used for other purposes besides butter. It is a very strong and substantial package, and would seem to be well adapted for the purpose for which it is intended.

\section{A METALIC PACKAGE WITH WOODEN COVER}

Is manufactured by the Metalic Butter Package Co.,

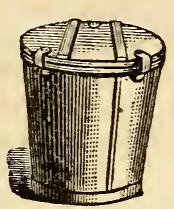

FIG. 44.

New York City, the general form of which is representer in Fig. 44. These packages weigh but 5 pounds, and can be put up in bales containing 20 packages each and shipped to any part of the country for a limited freight, as they occupy little space, while the covers, which are made of wood, can also be baled and shipped with them. This package. is made larger at the top than bottom, and can be readily stripped if desired, leaving a clean, smooth surface, with no waste of butter from black, dirty staves, often an objection in wood packages. The light weight also of this package as compared with wooden packages makes an important saving in freight which can be eredited to the profit of merchant or producer.

\section{THE EMPIRE BUTTER PACKAGE}

Is the invention of Chas. W. Grannis, of Gowanda, $\mathrm{N}$. Y. One of its main features is being double throughont. The outer surface is composed of wood, the inner surface of tin or wood as may be prefered. The two surfaces are placed apart, the spaces formed may be left unfilled or may be filled with fine charcoal, the latter is thought preferable as it is a protection against heat. 'The tin or inner lining is coated to gnard against rusting. This coating is entirely impervious to the juices of the butter, or boiling water, and is as sweet and clean as glass. The cover is composed of two entire circles secured together with the grain running crosswise which prevents warping.

\section{STONE'S TIN PACKAGE.}

This is simply a package in shape of the common tin pail, hut is surrounded with wood for protection. It is coated with a preparation of paraffin which, with the manner of securing the cover, are its chief features. 
THE METALIC PACKAGE DEMANDED BY THE TRADE.

Many dealers in butter say there are serious objections against the return butter pail. These pails have to be looked after and shipped back to the right parties, and the work is very annoying and perplexing. 'They ask for a metalic package that is sufficiently well-constructed to keep butter in good order during its transit, and at the same time so cheap that it may go to the consumer without the necessity and trouble of being returned. Such a package has not yet been introduced, but it is confidently believed by dealers and shippers that a metalic package miay be made to meet these conditions.

\section{SWEDISH SYSTEVI OF BUTTER-MAKING.}

Among chemists, who have had much to do in studying the nature of milk and its products, it has been known that for a number of years the experiment station of the Royal Agricultural Academy of Sweden in Stockholm, has been occupied with chemical investigations upon milk, its composition and alteration and the products obtained from it in the making of butter and cheese. I need only to refer to the ably conducted researches of Prof. Alexander Muller and his assistant Dr. Eisenstuck, to show that there is no higher authority recognized upon the subjects they have investigated. The Swedish Government, with wise forethought and praiseworthy liberality, has fostered these scientitic investigaltions concerning milk and its management in dairy prac tice, and the result is that some of the old notions in relation to butter and butter-making have been abandoned, and a new order of things inaugurated. And among these, the most remarkable change is the setting of the milk in ice water for the purpose of obtaining the cream. The fact that Swedish butter, under this process, has risen to that superior excellence that it equals, and not unfrequeutly out-ells all the choice brands brought into the London market, whether of home or foreign make, 
will be to most minds sufficient proof that the Swedish process is not without merit. I know from personal observation and experience how fastidious the better classes of London are in regard to their selection of fine grades of butter, and American dealers know, to their cost, how difficult it is to realize high prices on butter in England without it possesses the highest excellence in attributes that go to make up fine quality. Swedish butter has been quoted in the London market during the past year (1874) from 160 to 170 shillings sterling, and upward, per cwt., while the best American and Canadian in that market has brought only from 90 to 110 shillings.

\section{SIVEDISH METHOD OF TRRATING THE MILK.}

Experience has prcved that cream cannot generally be kept longer than 50 hours in the summer and from 70 to 80 hours in the winter, without affecting the quality of the butter. The milk is carried to the tactories every night and morning immediately after the milking, from the farmers not more than $1 \frac{1}{2}$ English miles distant. It is measured by the woman in charge of the place, who enters the quantity delivered. According to her book, the farmers receive payment at the end of every month for the quantity of milk delivered during the previous month.

\section{COOLING TANKS.}

For cooling the milk square cisterns or oval tanks are used, both being 24 iuches in depth. Their other dimensions depend upon the quantity of milk to be strained at one time, and upon other circumstances. Cisterns, manufactured at the carpenter shop of the company, are made of plank two inches thick, and inside nine feet long, and three feet wide. Such a cistern is large enough for cooling about 115 2-10 imperial gallons of milk. A loose grate, provided with a three to four inch wooden wedge is fastened to the bottom, inside the cistern. The pails for setting the milk are placed upon the grate, thus allowing the ice water perfect access under the pails.

\section{PAILS FOR SETTING THE MILK.}

The milk pails or tubs are made of iron and steel plate, and thoronghly and carefully timned inside and out. Originally, when the milk was cooled by water 
from the wells, these pails had a diameter of 18 inches and a depth of 24 inches.

\section{QUICKER THE MILK IS COOLED THE MORE CREAM.}

By long and careful experiments it has been ascertained, that the more speedily the milk is cooled down, the more completely is the cream separated from it. The consequence is, that not only is much colder water now used for cooling the milk, but the pails for setting it have also been reduced to the smallest diameter consistent with the other management of the milk, namely, about 9 inches, with a depth of 20 inches, holding about 3 5-14 imperial gallons.

\section{OVAL SHAPED PAILS.}

In order to be able to use the original pails, their bottoms have been taken away, and their sides pressed together, giving the pails an oval shape, with a small diameter of 7 inches and providing them with new bottoms. The cooling power of these pails has thus been greatly increased, and many farmers prefer them to the smaller cylindrical ones, as being comparatively cheaper and the milk in them more easily skimmed.

\section{ICE WATER METHOD.}

Besides changing the form of the pails in which the milk is set and cooled, other attempts have been made to quicken the cooling by using iced water instead of wellwater. The temperature of the well water is not lower than that of the soil, or from 42 deg. to 44 deg. Fahr. whereas the temperature of water in which ice chopped in small pieces is permitted to melt, may easily be reduced to 35 deg. or 36 deg. Fahr. Cold wells are not always to be found, but on the contrary are very rare in some districts, whereas ice may be had in this northern country at a very small expense. The ice water method is therefore now used at all the milk-houses as well as by nearly all the farmers who furnish the company with crean. While constant change of the well water, where such is used, is required in order to retain a low temperature, the ice water does not require to be changed more than a few times every year. The surplus water arising from melting of the ice. is let out by a small pipe placed at the upper edge of the tank. 


\section{THE QUANTITY OF ICE REQUIRED.}

At the milk-houses, it is calculated to be equal in measurement to the quantity of milk for the cooling of which it is intended; but with proper management two-thirds onght to be sufficient. The ice intended for the cooling cisterns is chopped in pieces of about three to four inches square, whereby its cooling power is greatly increased.

THE MORE THE ORIGINAL HEAT IS RETAINED WHILE BEING DELIVERED, THE MORE CREAM.

The milk should be delivered as soon as possible after the milking is done, and carefully transported, and it has hitherto been considered advantageous to cool the milk during the process of milking, and before being delivered. However, it has recently been stated that the more the origin:l heat is retained until the milk reaches the factory, the more cream will the milk yield, as the cream begins to rise as soon as the milk begins to get cold, and the straining and transportation of the cool milk causes a very injurious interruption in the rising of the cream, which consequently will'be imperfect. This seems very probable, but can only be proved by careful experiments. It is, however, a fact, that the shorter distance the milk is transported the more cream does it yield; other circumstances, as quality, treatment, etc., being the same.

\section{HIGHT OF THE ICE WATER.}

As soon as the milk is strained into the pails, they are placed in the ice water cisterns at a distance of about three inches from each other. Experiments have been made to ascertain the proper hight of the ice water, but have not led to any positive results. It may, however, be stated, that during the summer season and when the temperature of the milk-room is comparatively high, the surface of the milk should be on a level with the surface of the water, the upper layer of cream being thus kept as cool as possible; whereas during the winter season, or when the temperature of the cooling-room is low, the surface of the milk should be a few inches above that of the water.

THE TEMPERATURE OF THE COOLING-ROOM ought to be kept as low as possible during the summer 
season, but if possible never below 50 degrees Fahr. during the winter.

\section{THE TIME REQUIRED FOR THE CREAM TO RISE}

depends principally upon how soon the milk is cooled, but also upon the temperature of the milk as well as upon that of the ice water and of the room. If a milk pail (say of three gallons) be placed in the ice water cistern immediately after the milking and the temperature of the water does not exceed 35 degrees Fahr., the milk may usually be skimmed after a lapse of 10 or 13 hours; but it is better and safer to permit the milk to stand from 18 to 24 hours. At this low temperature the cream rises very suddenly, but is at first very thin, and requires a longer time to become firm.

\section{TREATMENT OF CREAM.}

The cream which is not sent to the butter factory immediately after being skimmed off, ought to be put into the ice-water bath without delay. It ought not to be kept more than two days during the warmer season and three days during the winter before being churned, as otherwise it will become bitter or acquire a bad taste easily detected in the butter. It may be considered as a fact that the fresher and absolutely sweeter the cream is, the better will be the butter.

THE CREAM OBTAINED FROM MILK COOLED BY ICE-WATER

is, as above stated, thin, and generally not as settled as that which rises from milk set in bowls or flat vessels, and kept in a comparatively warm room; and as a smaller quantity of butter is obtained from thin cream than fiom thick, the opinion is often expressed that the first-named method gives a less satisfactory result than the latter. It will be easily understood, howaver, that this is not the ease, if the merit of one or the other method is estimated by the quantity of butter obtained from a certain quantity of milk instead of cream. Nevertheless, it is true that the thin cream obtained by the ice method will give more buttermilk, as well as somewhat less skimmed milk, than that obtained by the well wate: method, the cre: m--etting in both cases being equally as perfect; but the loss, in itself insignificant, is more than covered by the finer 
quality of the butter, the better skim-milk, and the smaller expense for vessels and buildings required for the keeping of the milk during cream-setting, besides the other advantages of the ice-water method.

\section{SWEDISH BUTTER MAKING.}

A temperature of the cream of $57 \mathrm{deg}$. to $60 \mathrm{deg}$. Fahr. has been found the most suitable for making butter, but it depends somewhat upon the quality of the cream, the nature of the season, and the temperature of the air, \&c. The churns, which are best adapted for working by steam or water power, consist of a barrel somewhat conical at top, resting on a frame, and vertically moveable on trunnions. In this barrel a churn-staff, provided with two wings, rotates at a speed ' 120 to 180 revolutions per minute, depending upon the size of the churn, which generally contains from 17 to 60 gallons, according to the quantity of cream to be churned. The butter is obtained in about 45 minutes. It is separated from the buttermilk by means of a strainer, then placed in a tub of tin and carried to the next room, where it is further prepared. The butter obtained from each separate quantity of cream is then worked by hand in a beechwood trough of oval form, in order to separate the buttermilk. It is then tested by the managing dairymaid and classified according to its taste and other qualities in three classes, and afterwards weighed, the weight and quality being noted in the factory journal. Before churning the cream, fluid annatto is added in quantities suitable to the different seasons, giving the butter the color which is required for different markets.

\section{SALTING AND PACKING.}

The assorted lumps of butter are separately and carefully worked together, during which operạtion a certain quantity of salt, varying from 2 to 5 per cent. is added. The salt used is refined in Sweden, and is as pnre and dry as possible ; one quarter to one-half per cent of sugar is also added. When the butter is ready it ought to possess a waxy firmness. perfectly uniform in appearance. It is then packed in casks of beechwood, previously well saturated with brine, and containing from 60 to 100 pounds of butter each. Before closing the casks the name of the dairy where it has been manufactured is 
pressed in the butter, and finally the butter is covered by a piece of gauze, and thereupon a little salt. The mark of the company and the net weight in English pounds are painted on the cover if the butter is of the first quality. The casks containing second class butter are only inarked with the initials of the dairy, and third class butter is sold on the spot or returned to the respective deliverers of the cream. The butter is sent at least once a week to the market it is intended for.

KEEPING QUALITY OF SWEDISH BUTTER.

During the summer butter was placed for some time in a dry, cool cellar, and after two months it bronght the same price in London as fresh butter sent at the same time.

\section{PARISIAN BUTTER.}

For the Russian market, as well as for some home demand, what is called Parisian butter has been manufactured. Perfectly sweet cream, which is heated to from $176 \mathrm{deg}$. to $194 \mathrm{deg}$. Fahr., and then permitted to cool again to the usual temperature before being churned is used for this kind of butter, which is otherwise made in the nsual manner, but without adding annatto or salt. By the heating of the cream, the butter obtains a slight almond taste and seems also to keep longer.

\section{BUTIER-MAKIYG AT THE CHEESE FACTORIES.}

Within the last three or four years a good quality of butter has been made at some of the cheese factories. The plan adopted is to spread out the night's milk in the vats used for making cheese, allowing a stream of water to flow under the inner vat, or to flll the space between the inner and onter vats. The milk is by this means reduced to about 60 degrees, and what cream rises during the night is skimmed off in the morning and made into butter.

The morning's milk is then added to the skimmed milk as it comes to the factory, and is made into cheese by the 
usual process, except that a lower heat and less salt is used than for the whole-milk cheese.

By careful manipulation and skill, very nearly as good a product of cheese is made as at the factories making whole-milk cheese; at least, with good milk and high skill, experts are unable to detect the difference.

At one of these factories, which I visited in 1874, the delivery of milk for the day amounted to 6,839 lbs. The cream taken from the night's mess of milk made $87 \mathrm{lbs}$. of butter, and when the morning's milk was added to the skimmed milk it made nine cheeses of $\imath 2 \mathrm{lbs}$. each.

In some factories, in order that the night's milk may not be massed together in too large quantities, resort is had to a large, shallow pan set in a wooden vat with space between the two.for water. The milk is set in these pans from two to three inches deep, and a stream of coid water kept flowing in the space between the pan and the vat during the night.

\section{WHEY BUTTER.}

At the whole-milk cheese factories a process has been adopted for taking the butter out of whey and preparing it for table use. Whey butter is not equal in flavor or texture to the product manufactured at the butter factories. Still, by this process, whey butter may be made quite palatable, and, when fresh, it commands a fair price.

I have seen whey butter side by side in the markets with that made from cream in the usual way at farn dairies, and dealers have selected the former in preference to the latter, not for a moment suspecting its origin. Indeed, so fine have been some of the samples, and so neatly were they put up, that it has been sold when quite fresh at the Little Falls market for the same price as ordinary brands of butter made in the farm dairies.

Whey, butter soon deteriorates in flavor, and should be consumed when freshly made. We give description of apparatus and process of making as follows :

Apparatus.-The apparatus is a copper-bottomed vat 12 feet long by 3 feet wide and 20 inches deep. These dimensions may be varied to accommodate the size of the dairy. The vat sets over a brick or stone arch, and is accommodated to the use of 18 or 20 -inch wood. The floor is a slightly inclined plane toward the back of the 
vat. The vat and arch should be placed a little lower than the milk-vat, so as to enable the whey to be easily drawn off by means of a syphon.

The Process.-After drawing the whey from the curd into the vat over the arch referred to, one gallon of acid is added to the whey for every 50 gallons of mi!k, if the whey is sweet. If the whey is changed, a less quantity will be sufficient, and if the acid is not sharp, one pound of salt should be incorporated with it.

The acid having been added in the above proportions, heat is immediately applied to the mass until it indicates a temperature of from 170 to 180 degrees Fahrenheit. The cream now begins to rise and is skimmed off with a tin sooop; and when it has all been removed, it is set in a cool place and left to stand for 24 hours. It is then churned at a temperature of from 56 to 68 degrees, according to the temperature of the weather, and is then worked and salted in the ordinary manner of buttermaking. This process gives on an average 20 pounds of butter from 500 gallons of whey.

Making the Acid.-The acid is made by taking any quantity of whey after extracting the cream, heating it to the boiling point, and adding a gallon of strictly sour whey for every 10 gallons of boiling whey, when all the caseine and albuminous matter in the whey will collect. in a niass, and may be skimmed off. The whey is now left to stand for 24 or 48 hours, when it will be ready for use as acid.

\section{ANNATTO AND ANNATTOINE.}

The butter factories prefer to give color to their butter by having the cows well fed, and by getting up the cream as quickly as possibly after the milk is drawn. Sometimes, in winter, a little coloring may be used, and for this purpose, as well as for coloring the cheese, nothing has giving so much satisfaction as annattoine, or the dry extrict of annatto.

It is cut or made ready for use in the following manner : 1. Put two pounds of annattoine in four gallons of clear, cold water, and let it stand in this state one day, stirring thoroughly meantime, so as to perfectly dissolve the annattoine. 2. Then put two pounds strongest potash and one pound sal-soda in three gallons of cold water. 
When this is perfectly dissolved and settled, pour off the clear liquor and mix the two preparations (Nos. 1 and 2) together. 3. Let this compound stand two or three days, until the annattoine is cut or dissolved perfectly by the potash, stirring occasionally meantime. 4. For cheese, use about a teacupful for a thousand pounds of milk. Do not mix with the rennet, but put it in a little milk, and then mix in the mass of milk in the vats by. stirring it in thoroughly, just before the rennet is used.

If, a day or two after the preparation is made, the annattoine does not seem to be perfectly cut, so that specks can be seen, it is certain that the potash was not strong enough. Adding more of a stronger solution of potash will remedy the trouble.

When annattoine is used for coloring butter, a portion of the prepared liquor is added to the cream at the commencement of churning. It gives a very rich color, and may be used in winter-made butter with advantage. For winter butter a large tablespoonful of the preparation for five quarts of cream just before churning is the usual practice. Nichols' (English) liquid annatto is an excellent preparation for butter.

\section{THE SKIM-CHEESE DEPARTMENT.}

I have referred to the manufacture of "skim-cheese" as a part of the butter-factory system. I have said that the cream is dipped from the milk while it is sweet, and that the latter-then goes into the milk vats for making "skim-cheese."

It should be remarked that at the butter factories the quantity of milk to be manipulated is usually much smaller than at the cheese factories. In making a fancy product it is found advisable that the delivery of milk be kept within moderate bounds, say from three hundred to five hundred cows. The factory milk-vats are all essentially alike in form and size. They hold from five hundred to six hundred gallons each. 
There is a great variety of heating apparatus, boilers, steamers, tanks for hot water, and what are termed "selfheaters," that is with fire-box attached to and immediately below the milk-vat. This kind of heater was at one time very popular at the small butter factories where churning is done by horse-power, as it consumes but little fuel, is easily managed, and does as good work as the best.

In the more recent practice the tendency is to fit up the factory with a steam boiler and engine, because then an efficient and convenient power is at hand to do the churning, while steam can be employed for heating the vats, for cleansing dairy utensils, for warming the apartments by means of piping, and for other purposes connected with creamery operations.

As the "self-heaters," however, are useful in farm dairies and often may be desirable in small creameries, I give illustrations of those in popular use. As their operation will be readily understood from the cuts, it will be unnecessary for me to give a description of the various parts and operations of each.

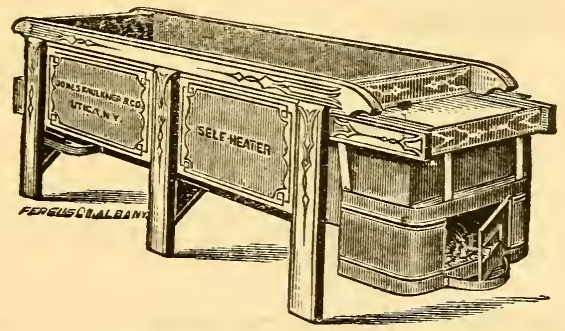

Fig. 45.-JONES \& FAULKNER'S NEW SELF-HEATING VAT.

In large creameriès steam has been and will probably continue to be the most popular method of heating. I have given illustrations of the most approved engines and boilers for factory use. The vats used in connection with steam are all nearly of the same character-the outer or wooden vat of clear, well-seasoned pine, the inner vat of large tin, imported expressly for this purpose. They are of different sizes, from 12 to 16 feet long and from 3 to $3 \frac{1}{2}$ feet wide, 19 inches deep, and holding from 450 to 630 gallons. 


\section{GANG PRESS.}

'The old style of press is being superseded by Frazer's patent, which is less cumbersome, more convenient, doing more work with less labor. (see page 160.)

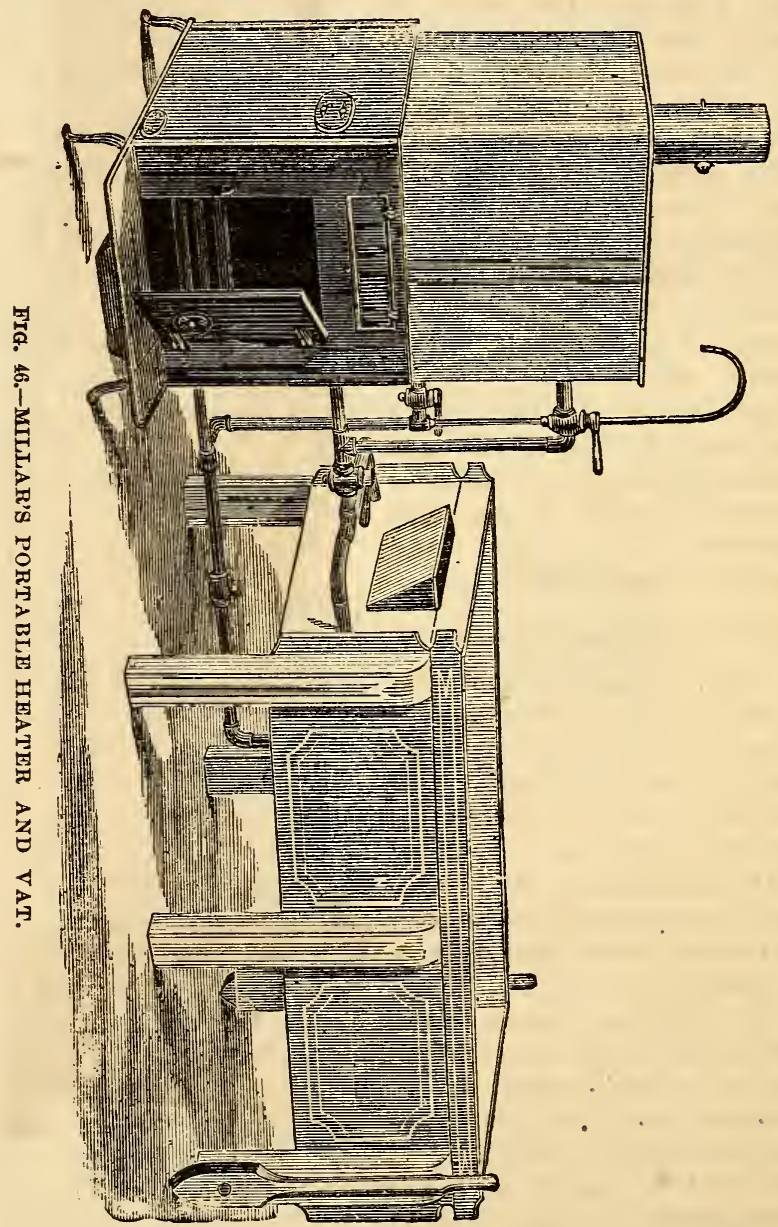

In this Press one screw is made to take the place of twelve to twenty, if necessary, each cheese receiving its 
full power; the bandage is easily and perfectly adjusted in the hoop before putting in the curd, and the hoops having bottoms, the curd is easily measured or weighed in, in even quantities, and when the hoops are prepared for press, the whole column is as quickly and more easily put to press than even one can be by the old method.

All press-boards and presscloths, with the necessary labor of cleansing, are done away with. No turning, trimming or after bandaging is required, but when once put to press they are allowed to remain under a constant pressure till finishe $\bar{d}$ and ready for the shelf.

SKIM-CHEESE MANUFAC'TURE.

The limit assigned for this book will not allow a lengthy description giving all the details of cheese making. This subject is very fully discussed in my large work entitled "Practical Dairy Husbandry," to which readers seeking extended knowledge must be referred.

In making cheese from skimmed milk the leading points of difference in the process from that employed for whole milk cheese are that the milk is set at a lower temperature and more rennet is employed. The "scalding " or " cooking" of the

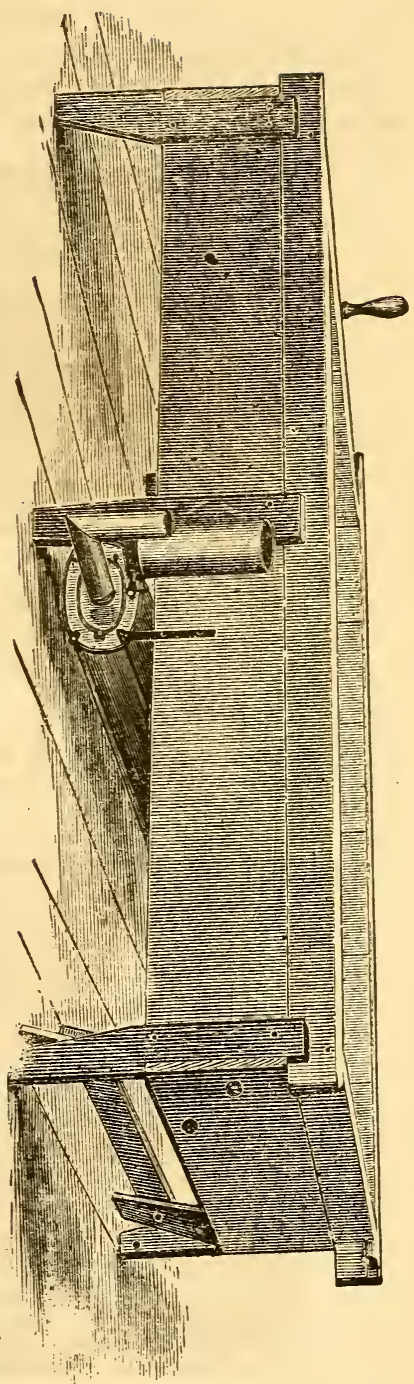

FIG. 47.

H. H. RoE'S VAT AN1) HEATER. 
curds, so called, is at a lower temperature than for whole milk cheese and the salting is less, but in curing skimmed cheese, the temperature of the curing room may be allowed to range higher. The reason why more rennet is required in skimmed milk than in whole milk, was first explained in my address before the Canadian Dairymen's Association, in which I detailed some of the investigations of Dr. Bastian.

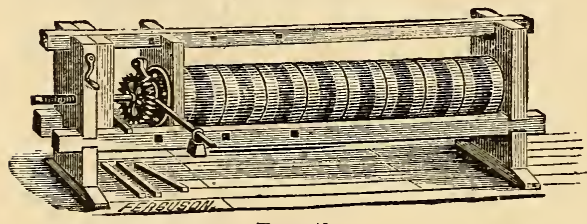

Frg. 48.

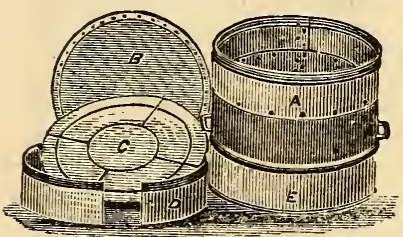

FIG. 49.

From experiments in this direction it appears that the fat globules are especially concerned in the transformations $\mathrm{or}^{\circ}$ changes which we wish to bring about by the addition of rennet to the milk and that if a large share of the fat globules are removed from the milk, the designed transformation is weakened, and more of the fermenting liquor or rennet will be required to supply the power lost by abstracting the fatty portions of the milk.

\section{SETTING.}

In setting skimmed milk a temperature of about 80 degrees Fahr. but sometimes lower, is employed in making it ready for the rennet, of which a larger quantity should be used than for whole milk cheese, the proportion should be graduated according to the amount of cream which has been remover, or as the milk is more or less rich.

\section{CUTTING AND SCALDING.}

It is cut with the perpendicular and horizontal knives in the usual manner as for whole milk cheese, and the process of working is similar; only the scalding heat should not be allowed to go higher than 86 degrees to 90 degrees Fahr. The curds are allowed to take on an acid condition and are salted at the rate of about $2 \frac{1}{4}$ to $2 \frac{1}{2}$ - pounds salt to the 100 pounds of curd; though it must be 
remarked the quantity of salt must be regulated according to the amount of moisture in the curds.

SIZE OF CHEESE.

Of late years the teudency has been to make skimcheese of smaller size than those usually made at the whole-cheese factories, because there is a demand in the market for small sized cheese which the whole-milk factories do not supply, consequently a small, fancy shaped skim will not unfrequently find a readier sale and better prices simply on account of its size. I have known half skimcheese, that is a cheese made from milk the half of which (the night's mess) was skimmed, to sell at the Little Falls market, at the same prices as those obtained for the best fancy whole-milk factories, and these rates were obtained for the whole season. The cheese was of good quality, but the rates were maintained on account of the smaller and more desirable size as compared with the fincy whole-milk cheese, offered at that market.

The best temperature for curing whole-milk cheese is at about 70 deg. Fahr. For curing skim-cheese the temperature should be several degrees higher, in order to keep up the necessary fermentation by which the proper changes may be brought about for breaking down the caseine and effecting a more complete assimilation of the moisture, so as to make a mellow and plastic article of food.

\section{IMPROVING SKIMINED MILK FOR CHEESE MANUFACTURE.}

Since the wide-spread introduction of creameries, and the general tendency to increase the production of butter through the creamery system, fears have been entertained that skim-cheese manufacture would be carried to excess. Already the leading cheese merchants of the country complain that there is an over-production of this class of goods. They say that often the markets are crowded with these inferior goods, mush to the detriment 
of whole-milk cheese, dragging down prices. An excellent reputation has now been established for American cheese in the markets of Britain, and the demand abroad for good cheese at good prices is sufficient to meet all surplus above home wants in American production. But poor cheese is not wanted abroad, except at very low rates, and the handling of such cheese is attended with great peril to dealers. They say, therefore, that an increase of skim-cheese manufacture must in the end destroy the good name of American cheese in the foreign markets, and they therefore urge that in creamery practice, butter only should be made, and the skimmed milk be sent to the farm to be used in feeding domestic animals.

Mr. H. O. Freeman of Sherburne, Chenango County, $N$. Y., seems to have hit upon a plan for avoiding all the difficulties named-of converting the skimmed-milk into a palatable and healthful article of food, and which sells for a good, fair price, both at home and abroad. And though it miy lack the flavor and quality of our best fincy whole-milk cheese, still it is meaty and possesses none of the characteristics of the ordinary skim-cheese, but compares favorably with much of the whole-milk cheese on the market. I have been using the so-called "oleom urgarine" cheese on my table and I agree with Prof. CaLDwell and other's who have used it in their families during the past year, that the cheese is palatable and makes a good, healthful article of food. I am informed that dealers who have handled the so-called oleomargarine cheese during the past year, have met with good returns in its sale, both at home and abroad, and that no complaint has been entered against it in the markets or by consumers; and that they have faith in the process, is indicated by their becoming stockholders in a company for prosecuting its manufacture.

Oleomargarine has been for the most part employed in the manufacture of this cheese, but whey butter or any low grade of butter, if clean and purified of its rancidity, may also be used successfully.

As much interest has been manifested concerning this new process for improving skimmed cheese, I give an illustration, Fig. 54, of the Ridge Mills Creamery, near Rome, Oneida County, N. Y., and the process of manu- 
facturing. This creamery has but just been erected and goes into operation the present season, 1875, for the first. It has many improvements and may be regarded as one of the model creameries of the State.

Referring to the ground plan, Fig. 50, the main structure is 75 feet by 40 feet, and the curing rooms 100 feet by 25 feet. The wing, or engine and boiler-room is 26 by 26 . $A$ is the receivingroom, and 1 the weighing cau; $\mathrm{B}$ is the cooling-room, and 2 the cooling-vats; $\mathrm{C}$ is the make room, 3 the cheese-vats and 4 the churd-sink; D is the press-room and 5 Frazer's gang presses; E is the butter-room and 6 the cream-vats; 7 the churns ; F, engine, boiler and fuel room; $\mathrm{G}$, cellar under curingroom; H, boiler; I, engine; $J$, cold water tank; $K$, hot water tank; $L$, vessel to melt the oleomargarine by steam.

Fron $A$, the receiving-room, the milk keeps moving towards its destination for cheese; and this, after

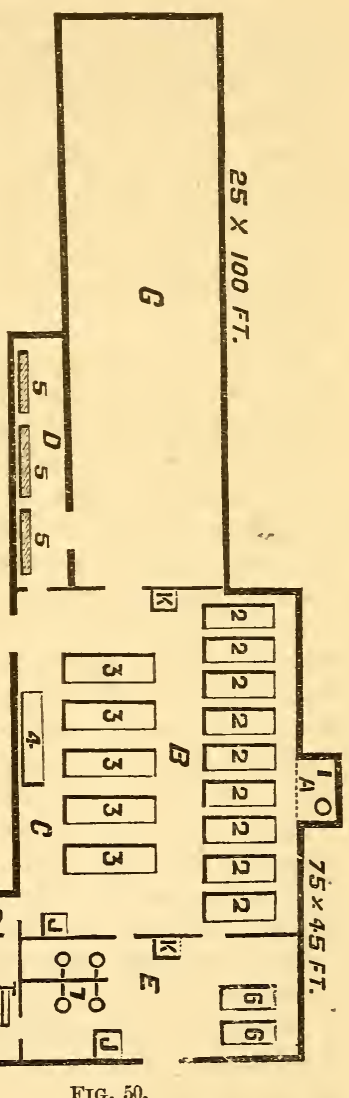

FIG. 50 .

being taken from the press, is readily hoisted to the curing rooms. The cream, when separated from the milk, also takes its separate course and forms a distinct manufacture from the cheese. The room $B$, has a raised floor of 2 feet above the make room, (see Fig. 51). So that after the 
cooling vats are skimmed the milk is readily drawn off into the cheese-vats through a faucet in the bottom of the cooling-vat, and conducted by tin conductors into the cheese-vat. The manner in which this is effected, is illustrated in Fig. 51, which gives a sectional end view of the factory.

The cooling vats are similar to a cheese-vat in con-

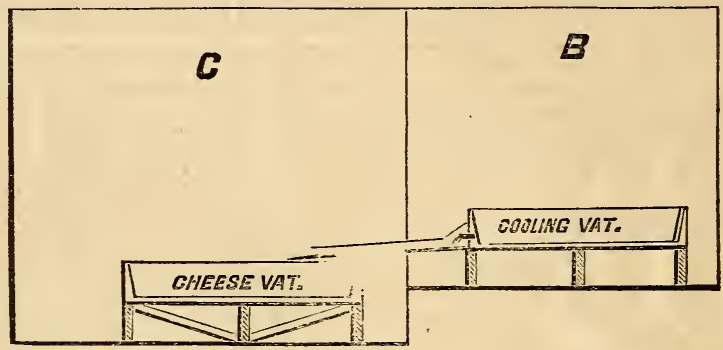

FIG. 51 .

struction, with the addition of a tin cover, setting on top, over which a thin layer of cool water is run and the cool temperature caused by it falling upon the milk cools the latter quite rapidly. This cover is lifted up by weights

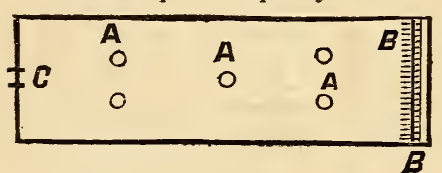

FIG. 5:. when the milk is to be skimmed and the vat washed preparatory to receiving the fresh milk. The subjoined cut illustrates a face view of the cover, Fig. 52 .

The water runs in througin a plpe at the end, B B. the pipe being perforated, and distributes the water in a shower. The water after passing over the top, runs into the wooden vat and surrounds the tin vat on the sides and bottom, running off as fast as it runs in over the top of tin cover. The five holes, A A A, represents five ventilators, say two to three inches in diameter, to allow the escape of warm air.

The depth of this cover is from two to three inches and, as before stated, the water running over it is not deep, say one-fourth of an inch. The Ridge Mills Creamery, like all those owned by the American Dairy and Commercial Company, is built on principles which ensure, as far as a wooden structure can, the equal temperature of the whole 
building. " It is filled in on all sides with saw-dust and the top story ceiling is covered with the same to the thickness of some six inches. The curing-room is warmed by steam pipe, supplied from a 14-horse power boiler. Mr Freman

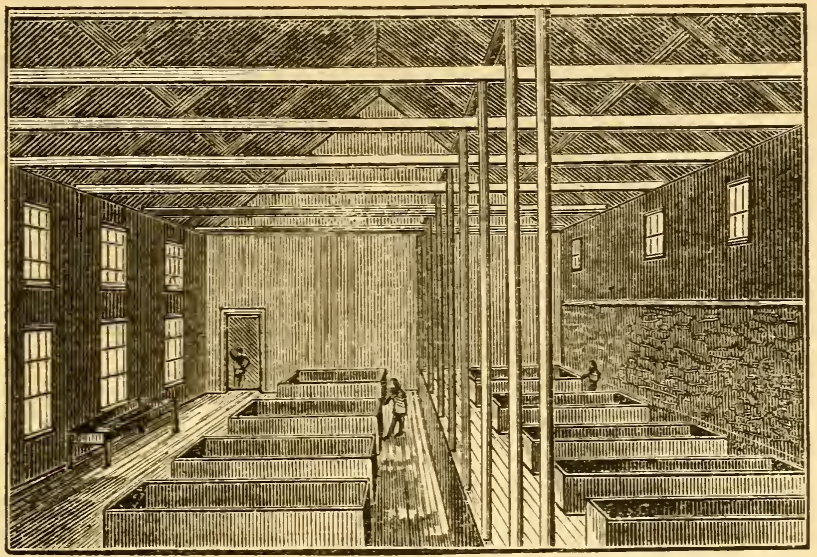

Fig. 53-Iterior View OF RIDGe MILls CREAMERY.

thinks a great mistake made by many factories is the inadequate power of the boiler, and that too many place a boy in this department to do a man's work. Mr. Freman gives the following details in regard to the mannfacture of oleomargarine cheese.

TWO METIIODS OF SETTING MILK.

We use two methods of setting milk.

First. In some of our factories we set in tin coolers, $9 \times 20$, placing them in pools of cool spring water from 24 to 48 hours, according to season of year and temperature of atmosphere.

Second. In other four factories we nse a cooling vat holding about 3,500 pounds of milk, similar to a cheese vat, except there is a corer upon the same,over which water is run and returned under the vat. In this cover there are ventilators to enable the warm air to escape, as it is. driven ont of the milk.

AMOUNT OF BUTTER TAKEN FROM THE MILK.

Taking the season through, we obtain fully three 


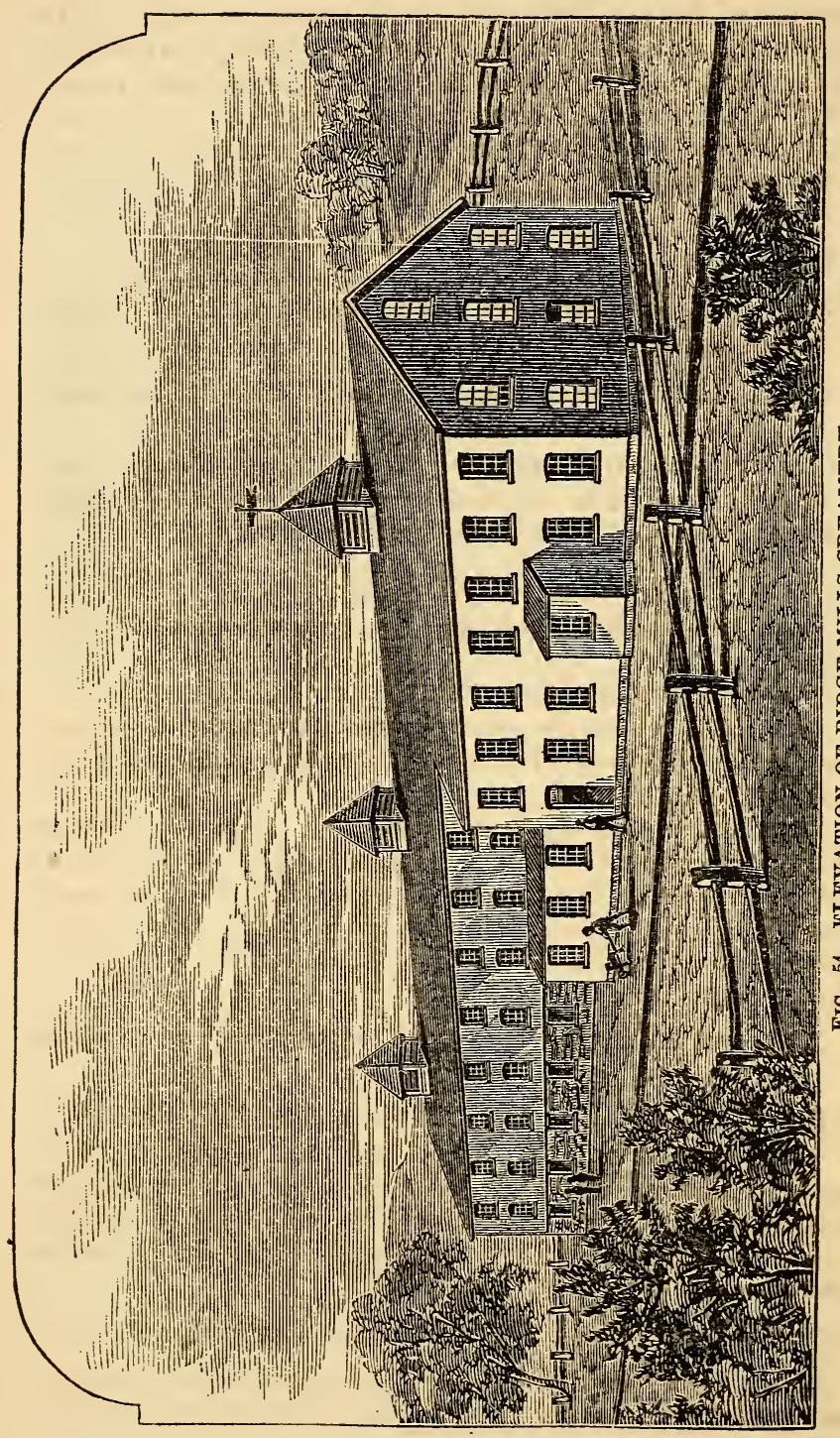


pounds of butter from each one hundred pounds of milk received. In some locations we can obtain more butter, but the above is a safe, estimate. At the McLean creamery, Tompkins Co., N. Y., the result for the past season of 1874 , was one pound of butter from each 32 41-100 pounds of milk.

\section{MILK NOT ALLOWED TO SOUR.}

The cream is talken from the milk before it sours, in order to properly preserve the skimmed milk for manufacturing into cheese.

AMOUNT OF OLEOMARGARINE ADDED TO THE SKIMMED MILK.

To every one thousand pounds of skimmed-milk, there is added ten pounds of oleomargarine, and the prodnction of quality of cheese has been described.

\section{PRODUCT MADE.}

From one hundred pounds of pure unskimmed milk we obtain :

First. 3 pounds of butter.

Second. $6 \frac{1}{2}$ pounds cured cheese, to which is added, one pound oleomargarine, which weight is retained in the curing of the cheese.

In other words, after repeated trials of making on the same day cheese from full skimmed milk as usually practiced, and cheese from full skimmed milk with oleomargarine added, it has been found that the latter when cured fully outweighs the former by the amount of oleomargarine added to the latter.

A LESS WEIGHT OF MATERIAL OBTAINED THAN FROM FULL MIL CHEESE.

In making butter and cheese from the same milk, there is not so great a quantity of material obtained from, say 100 pounds of milk, as in making full cream-milk cheese, since the buttermilk contains caseine to a greater or less extent, and we do not use the buttermilk in the manufacture of cheese.

SOUR CREAM MAKES MORE AND BETTER-KEEPING BLTTER.

It has been found that souring cream before churning increases the production of butter, and also produces a 
keeping quality of butter. The sour buttermilk may add to the quantity of cheese, but the quality is not such as commends itself to the consumer.

\section{COST OF OLEOMARGARINE.}

The oleomargarine costs in New York city from 14 to 15 cents per pound, and therefore, if the cheese made from skimmed milk and oleomargarine should sell for 14 or 15 cents per pound, the cost of fat, added, would amount to nothing, as it has been proved the fat increases the weight of the cheese fully as much as the quantity used.

\section{MODE OF MANUFACTURE.}

The mode of manufacture of oleomargarine cheese is very simple, and differs but slightly from the manufacture of all other cheese. The skimmed milk is placed in the usual cheese vat and heated to 92 degrees Fahrenheit, when the oil, fat, or whatever you may choose to add, so long as it is "fat"-having first been melted in a separate vessel,-is added to the skimmed milk and stirred from 3 to 5 minutes, or until an emulsion is effected, when remnet is added sufficient to cause coagulation in from 8 to 10 minutes, and thus the fat added is made to enter into the composition of the curds while the latter are in a nascent state. The curd is then cut and worked in the manner of all careful cheese factories, and such fat as is expelled by cutting off the curd rises on top of the whey and is skimmed off before the latter is drawn, and is used the following day.

SET AT HIGHER TEMPERATURE AND COAGULATES MORE

\section{QUICKLY.}

You will observe that we set at a higher temperature than is usual in the factories of this country, and it is found necessary to do so in order to produce the proper emulsion of the skimmed milk and fat. We also set quicker; but the higher temperature requires but little more rennet to accomplish the quick setting than the ordinary heat applied to milk for slow setting. 


\section{N D EX.}

A eration............................. 66

Annattoine........................ 155

Annatro, Nichols'................. 156

Boiler, Anderson.................. 122

- - and engine, Jones \& Faulkner......................118-119

- - und engine, Roe's............ 120

_ - and engine, Charles Millar. 119

- - and engine, Irun Siave.... 119

Butter........................55-60

- - additional suggestions in working, washing and salting $10 . \mathrm{j}$

- - Artiticial ...................... (i0

- - Associated ditirying.......... 89

- - Amount from given quantity milk at Cold Spring Fuctory.. 130

- - Brining...................... 141

- - Box for factory ............... 128

- Cause of rancidity in.......... 60

- Causes that delay coming.... 133

- - Churning and wasling....... 11.

- Coloring..................... 156

- Composition of ................. 56

- Composition of fatty acids of 5 - $;$

- - Concerning and how to keep 140

- Concerning the keeping

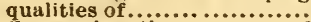

- - Concerning the manner of working.................... 139

- Consumption increases as quality improves...............

- Crop, number of cows required for....................

- - Crop...........................

- - Dake process.................. furm dairy................. 13:

- Fxplanation of rancidity iil.. 57

- - Factory, plan of first......... y3

- Hactory plan of for large pans....................127-128

- - Flavoring oils of............ 55

- How rancid may be purified. 58

- Keeping qualities of Swedish 153

- Making at the cheese fuctories.

- - Making, Colvert's process of 69

- - Making, points concerning.. 86

- Making premium on Shallow

- Setting System

- Making Swedish....................152

- milk, expelling.................. 102

- more from churning milk than cream................. 136

- - more obtained by nixing milk of different cows........

- more olein in summer..........

- - Parisian...................... 15:

- Philadelphia................. 68

_ - Philosophy of making and keeping.
Butter Preservation of, Girard's - pounds of milk required for at Factories................ 124

- - Preserving of, in France..... 141

- Preserving, sugar and saltpeter....................... 142

- - Preserving unother rule.... 14:

- Preservation of ............... 140

- Preservation of, Belins' process........................ 141

method .................. 1411

- - Preservation of, Redwood's process..................... 14

- Price of, advancing ubruali.

- - Prof. Caldwell's views un the composition of ............... 5

- Rate of consumption.......... 6

- Restoring rancid............ 142

- - Salting and packing, Swedislı system................ 152

- - Table, showing experiments 5 !

- Saltpeter and sugar for preserving, in Orange Co......... 103

- Washing the...................138

- What the appearance of, should be.................... 137

- - Whey........................ 154

- Whey, process of making.... 155

- - White specks in.............. 87

- - Vorking in. salt.............. 106

- - Working the................ 104

- - Working and salting ai Union Factory.............. 113

- - Worker.......................104-64

- - Worker, Chinipion.............. 10.5

- - Worker, Eurekı................64-65

Cans, Carrying ventilated.............116

Wickuti's ventilating........... 11

Churns and Chuming.............. 9ti

Churns.......................... 63

Churn, Barrel......................... 101

- Blinchard..................6.6.6.

_ - Blanchard's Factory........100-101

- Dash and walking-beam..... 98

- Disher....................... 9

- Factory.......................... 101

- Powers...................... 64

Tornado..................... 6it

Whipple's rectangular....... 64

Coecal Extremities or follicles....... 39

Colostrum or first drawn milk of the cuw................... 37

- Cumposition of.............. 3s

Composition of milk, cream and butter.....................

Cows breathing foul air............ 17

- Brief summary of items in the cire of milch................ 15

Care of $\ldots \ldots \ldots \ldots \ldots \ldots \ldots \ldots . . .14$

Cure of .......................... 1!

Cleansing the blood of........ 19 
Cuws, docility of temper, how acquired........................ fects the milk.............. Jerking out of stanchions...... Jerking out of stanchions..... Number required for the butter crup...................... Should be fill fed.............. Small breed, richest milk.... The average butter product wf ............................ The, for butter darying ...

- View of udaer of..............

- Water after salting...............

Circése. Skim. cutting and sealding.

- Skim, coloring.................

- Skim department of...........

- Skim, miluufucture.............

- Skim, setting..................

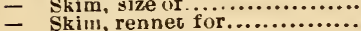

- Oleomargarine....................

- Oleomargarine, amount of

- Oieomarggirine, butter taken from milk..................

- Oleomarrarine, milis not allowed to sour for.............. 167 Oleomargarine, milk set at

higher temperature......... 168 oleom rgarine mode of minu-

facture ................... 168

- Olenmargarine. setting the

milk................. 169

- Oleumatianine, weight less

than full milk............... 167

-- oleomargarine. product mande 167

Press, Frazer's Gimg....... 158-160

Cream, Analyses ot, different authorities .................... Agitation of in Churning..... 137

- Agitation of ................. 1378

- Composition of....................

- Cumposition of different simples of....

- Churning, the best temperi-

ture for................... 137

- Cliurning at Cold Spring

Creamery.................. 129

- Gruge per cent................ 11

- Obtiined from milk couled by

ice wil ter. Swedisl system... 151

- Of first drawn milk poorer

than that of last drawn...... - Percentige uf, in milk.........

heat is retained ............. 150

- Striliner..................

- Sour, makes more and better

butter..................... 167

- Temperiture of, when churns are started..................

Time required to rise. Swedish

system.................... 151

- Treatmeit of, Swedish sys-

tem...................... 15

Cresmery, Cooling Vits for........ 164

- For a small number $n \dot{f}$

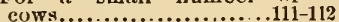

- - Interior view of ............... 165

_ Larre pan system............... 124

- Piil and pool system......... 92

- Plan for a large.............. 114

- - Rldge Mills................... 16.

- - Ridge vills, elevation........ 166

-. - Ridge Mills, plan of .......... 163

- - Reports........................ 131
Ditirymen Questions for ............

Uairying, Winter................... _ Mr. Buies; practice.............

Dairies. Farm .................... 61 Dairy-rum, IVilkinson's descrip9 tion of....................81-85 Dairy Wilkinsun's Gulf Stream.... 78

- Plan of Gulf Stream .........82-83 - Wilkinson'sSuper cooling duct 81 - Wiikinson's, reversing the circulation..................... 80 - Wilkinsen's, action of the duets...................... 79 Wilkinson's. Sälubrity secured 80

Fuctories Oryanizing.............. 89

Factory, Butter bux.............. 111

- Plan for a butter ara cheese combined .............122-123

- Plall of butter on the large ur shalluw setting system... 127 17he new departure in management................ 90

Fat, Composition of liquid in marrow...................... 56

- More the less space of time intervening between milking... Fats. Stearine and Oleine in......... 56 Feeding........................... 26. Garget, Saltpeter for............... 19 Glycerides........................6 60 Grass and grain feeding.............. 20 Grisses are social................ 29

Grass, different orier of seeds for pastures than meadows....... 30

- First turning to............... 19

- June, wire, meidow, fescue, and orchard.................. 28 Virieties esteemed for butter dairying ....................... 27

Hoven, Remedy for.................. 20

Ice-water, light of, Swedish........ 150

- - Methor. Swedish............ 149 Ire, Quantity required, Swedish..... 150 Mammary Gland, mode of action of 43 Margarine,Siuposed composition of 59 Milk, A mount of butter and cheese in, tiables of .................12-13

- Best from young animals...... 40

- Butter in.................... 54

- Cellar with ice-house attachment......................... $7^{2}-7 t$

- Churning the ...................... 135

- Milk Cellar, (rozier's........... 74

- Coming in....................... 19

- Composition of new...........46

- Composition of Skimmed...... 50

- Concerning acidity in........ 86

- Considered in its physiological and clicmical relations......... 35

- Death from using impure....... 22

- Diseased from tiltiy stables and diseased vegetables....... 21

- Diseased, nature of the poison uncertain.................... 22

- Devonshire plan of scalding... 77

- Difference in composition of in different animals........... 47

- Deep and shallow setting of... 88

- Fitty mitter of ............... 46

- Forcing air into..............6. $60^{\circ}$

- Globules, largest in Jersey cows...................... 45

- Globules, microscopical appearance of .................. 36

- How affected by brutal treat ment of cows..............20-25

- Influence of insufficient food.

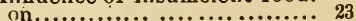

- Manugement of, carried to the creamery.................... 116 
Milk, House, Farm duiry.

- Millner of treating......... 65

- Means employed for detecting diluted..................... 118

- Percentage of cream and butter in.

- Poisoned by..... imalcui........

- poisoned by violent emotions or shocks of the nervous system.........................

- Ruom artificial heat in. counteracts the influence of thunder sturms... ...........

- Quicker couled, the mure crean....................... 149

- Ronm, heating the............. 75

- 8calding the.................... 76

- Secreting fullicles and ducts arritngement of................

- Skimmed, amount of oleomargarine adjed................ 167

- Skim, improving for cheese.... 161

- Vats. factory................... 156

- Swedislı treatment of........... 148

- Tibles of ........................12-13

- Testing of each animal......... 10

- 'I'heory of souring............. 54

- Typhoid fever germs communlcated through........... 24

- Treatment of.................... 112

- Uniformity in the composition of.......................... 52

- Pan, Cowles........................... 127

- - Jewett's....................... 126

- - Orange Co............... 126

- Setting for cream at Cold Sprin. Cre:umery................ 129

Oleomargarine. Cost of............. 1 168

Overstocking ......................... 30

Package. Empire butter............. 14t

- - Ice for butter prints......... 111

- The metalic demanded by the trade................. 147

= - Metalic euameled butter... 145

- - Stone's tin.................... 146
Package, Roll butter in tin crses... 144 - - Roll butter for market..... 143 - - Ro!l butter in jars, prepar. ing the brine, etc.......... 144

- Butter.......................... 107

- - White's butter................ 110

- - for butter prints .........110-111

62

- Butter, Philäelphia..............

- Butter, Wescott's Return....., 10s

- Cleansing...................... 62

- for setting miiik, Swedish sys-

tem........................... 148

- and Cream Dipper................ 95

- Oval-sluaped. Swedish system. 149

P:uns, Bunnell \& Brown's Iron Clad $76-77$ Jewett....................... 125

Results from the Union Creamery.. 114

Salt weigher........................ 130 Salting after expeiling butier-miik 102 cows...................... 17 Philosophy of, for butter.... 138

Sciles, Fuctory .................... 117

Secretion.............................. 38

Spring House ........................ 67

Sto - Pennsylvania......... 68 Important considerations in

the care of ................. 26

Stenmer and Culdron, Eagle.......... 121

Tanks, Cooling, Swedish .............. 148

Temperature of Cream for churning at Cold Spring Factory 130

- Controlling in dairy rooms 67

- cooling roum, Swedish... 150

Vaccintc Acid........................ 59

Vat, Cream............................. 115

- and Heiter, Roe's................ 159

- Jones \& Fuulkner's............... 157

- Portable Heater, Miliar's...... 158

- Self-heaters..................... 157

Ventilation........................... 18

Vault, Construction of .................. 72

- - Dry system....................

二- Locationn............................. 72

- Milk, and churn room.......... 73

Water for Cows...................... 19 


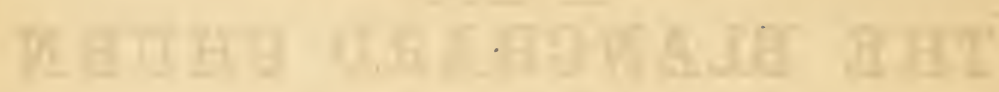

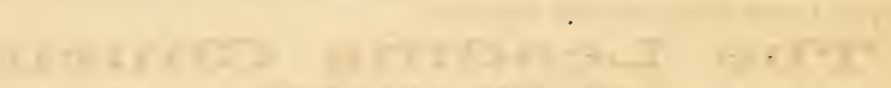




\section{"cet THE bEst."}

\section{THE BLANCHARD CHURN}

Combines more good qualities than any otber now made. It has passed the experimental stage, and has boen proved, and im-proved, and ap-proved, duriug the past tuenty-five years, until it is now

\section{Tine Ineading Olaurin OF 'THE: COUNTIRY.}
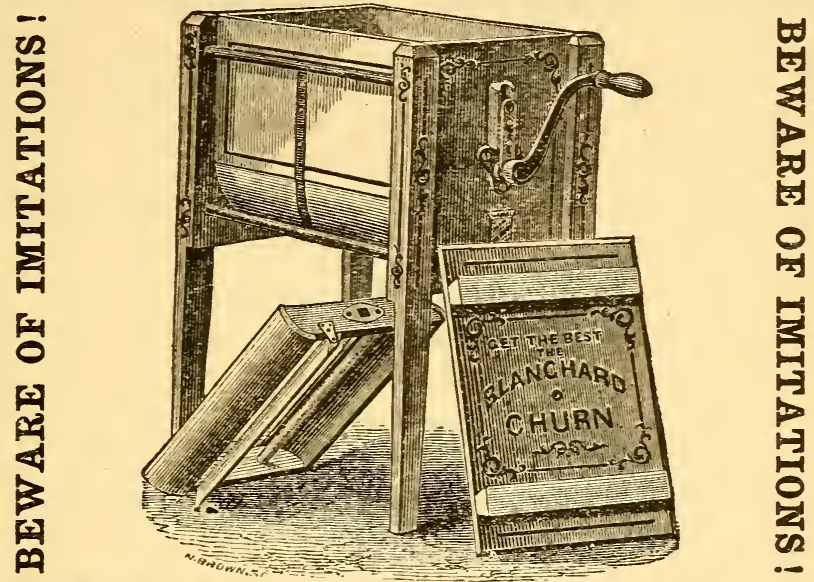

Orer 75,0?0 of these Churns are now in successful operation.

They always do their own talking when they are once introduced.

No other Churn is made of as good materials, or as faithfully. We challenge comparison.

It cannot get out of order because it is so simple

Because it is so siniple and thoroughly made, it is very durable.

It has no cog wheels or gearing.

it works the Butter free from buttermilk in the Churn, without any change of dasher, quicker and better than it can be done by hand. It works in the salt in the same way. it is a

\section{PIRTבCY AUTOMATIC BUTIPR-MATER. SEVEN SIZES MADE.}

No. 3. for about 2 gallons of cream......\$6.00| No. 7. for about, 18 gallons of cream... \$12.09

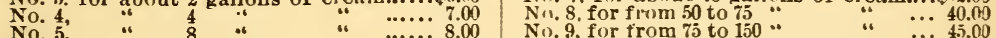

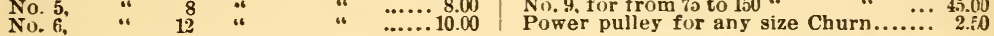

The Nos. 8 and 9 are Factory Churns, to be used with power, and are every way adaptf:d for use in Factories or large Dairies. They are "the best" made.

In offering this Churn to the public, we do so in perfect conflence that it is, without question or qualification,

$$
\text { The Very Best Churn Made. }
$$

We guarantee it to be FXACTLY AS REPRESENTED. Should it prove to be ntherTise or not to give ENTIRF SATISF AC'IION, it may be returned to us at OUR EXPENSE. F GIVE THEM A TRIAL..ES

For Churns, Agencies, or full descriptive Circulars, address

THE SOLE MANUFACTURERS, PORTER BLANCHARD'S SONS, Concord, N. II. 


\section{DAIRYMEN, ATTENTION !}

We call the Attention of Parties interested in Butter and Cheese Factories to the
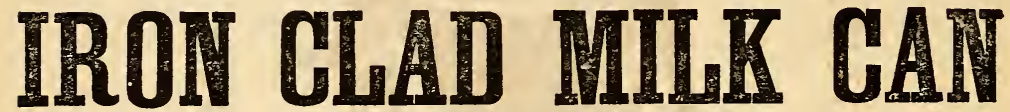

The only recommend they need is to say that there are now in use in the

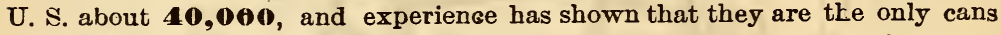
ever made that will stand the hard usage they are subjected to, in transporting the milk from the Dairy to the Factory.

For Sale by all the Principal Hardware and Tin Dealers

\section{in the conntry.}
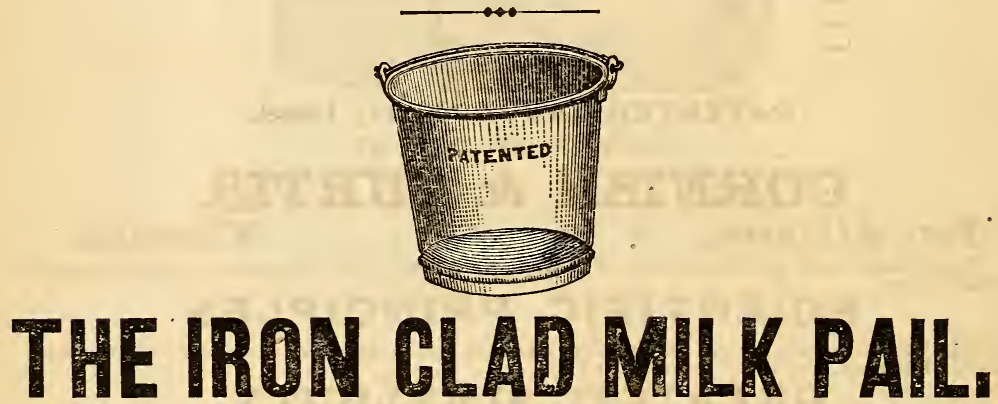

IMPROVED.

We call particular attention to the above Pail, as it is superior to anything of the kind ever manufactured. Instead of making them of tin, in the usual way, they are put together of IroN, the cylinder being in one piece, and much heavier than the common stock used; after which they are linned, making them as one solid piece. By this process we are able to fulnish the most durab'e Milk Pail ever manufactured, for the same price of the common tin one. Send for a sample.

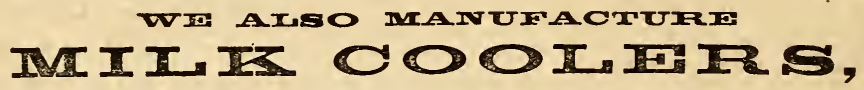

And all goods connected with the Butter and Cheese Interest.

Circulars, etc., sent to any party addressing the

IROAT CIAD CAIT CO., 23 Cliff st., INew York. 
" IHE BEST IS NONE TOO GOOD."
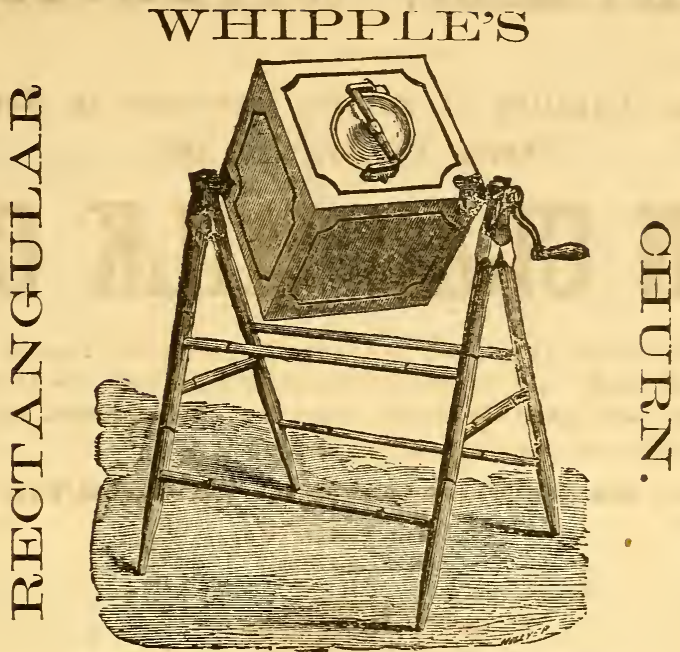

PATENTED JANUARY $21,1868$.

MANUFACTURED ONLY BY

\section{CORNISH \& CURTIS,}

\section{Fort Atkinson,} to all those

\section{SCIENTIFIC PRIRCIPLES}

essential to the production of the greatest quantity and kest quality cf butter with the least. labor. Presents a rare combination of the

\section{GREATES⿱彐⺀ SIIPIICITY,}

with the maximum of effiriency. for although it is onlv a cubical box, suspended at Ita diagonal corners. yet the successiv: operations of churuing. washing and salting the butter and cleansing the churn, are performod by simpiy

\section{期}

Made of the best material, by competent workmen, it cannot get ont of order, as it has

\section{NO GEARIHG, DASHER, OR AMITATORS}

of any kind, and flfty per cent. in lubor is saved by doing without them.

In confirmation of the foregoing, we are kindiy pernitten tu refer to the followin? named gentlemen, each of whon has given the "IRC'TANGUCA R" a thurough trial: Hon. X. A. WILlARD, Authur of this Bonk; II n. STEPHEN FAVII.. Pres. Nurtliwester! Dairymen's Association: D. IV. DAKE. Pres. National Butter and ligg Association: G. li. Nolkow. Dairy Editur Western Rural. and wide:y and f. vorably kwown as a Lecturer on Dairv Husbandiy; 'Hester HAzEN, Pres. Wisconsin Dairvmen's A sociation.

Hundreds of other references, frim prominent dairymen in all sec.lons of the country. might be given, if space permitted.

Five sizes made, ranging in cilpacity from four to thirty-five gailons, and in price from $\$ 7$ to $\$ 20$.

SAMPLE CHURNS sent for exilnination and trial to towns where we have no Agents, at regular WHOLESALE RATES.

We make no consignments on commission, neither do we slip Churus to le paid f,s when sold.

for Churns, Agencies or Descriptive Circulars, send to the Sole Manufacturers,

CORNISH \& CURTIS, Fort Atkinson, Wis. 


\section{STEEI AND IRON PLOWS.}

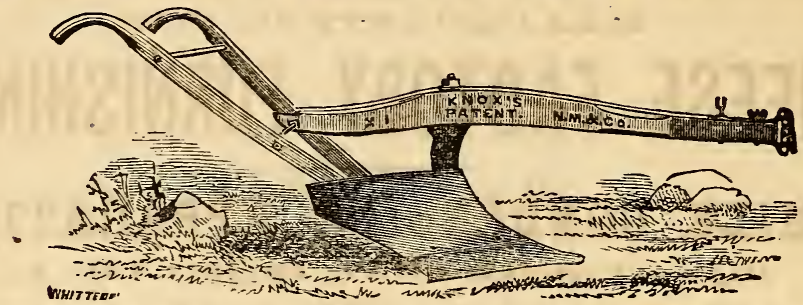

Knox's Patent and Improved Eagle. Hakes' Improved Swivel for Side Hill and Level Land. Boston Steel

Clipper. Sessions and Knox's Patent Hard Steel. ILapes' Improved Subsoil.

\section{THE AMERICAN HAY TEDDER,}

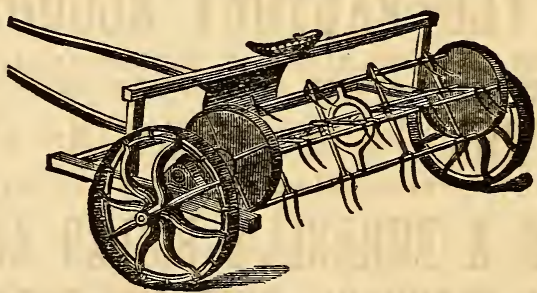

Enables the most important Agricultural product of America to be cut, cured and stored in the barn in one day. It improves the quality and increases the value of the hay crop. Its use prevents all risk of damage from storms and sudden showers. The Machine is simple, durable and of light draft. It was awarded the New England Agricultural Society's only First Prize, at the Great Field Trial at Amherst, Mass., as being superior to all others, and the best and only perfect machine for tedding or turning Hay.

\section{IMADE OINIT IBT AMES PLOW COMPANY,}

Manufacturers of Agricultural Implements and Machines, Dealers in Seeds, Fertilizers and other requirements of Agriculturists and Agrieultural Districts. Factories at Worcester and Ayer, Mass.

Warehonses, 53 BEEKHAN STREFT, New York, and QDINCY HALL, Boston. ORDERS FILLED PROMPALY.

Price Lists and Descriptive Circulars on application. 


\section{FARMERS AND CHEESE FAC'TORYMEN :}

IIEADQUARTERS FOR

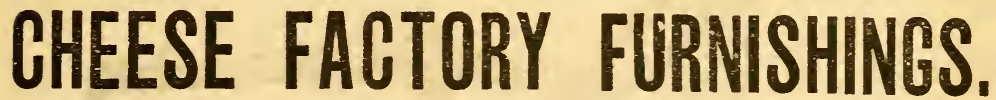

\section{MILK CONDENSING APPARATUS,}

Highest Premium Hoilers, Engines, Vats, dre.

FAIRBANIIS' SCALIS. EXYRA INDUCIMIINTS.

GANG PRESSES, SCREW PRESSES,

PATENT CURD KNIVES-Lower than Ever Before.

PATENT CURD MILLS, CURD RINGS, CURD SINKS,

RENNET and ANNATTO JARS, THERMOMETERS,

ALL GLASS AND TIN GOODS.

CHURNS AND EVERYTIING FOH BUTTER FACTORIES.
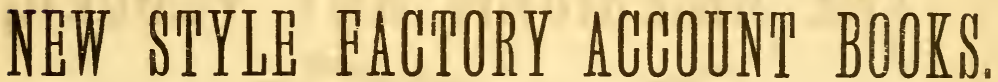

THE FINEST IMPORTED BAVARIAN, ENGISH AND IRISH RENNETS,

SALT, ANNAT'TO, ANNA'T'TOLNE, AND ANNA'T'TO SEED, BANIDAGE, \&c., \&C.

\section{PATENT CHEESE BOX HOOPS, RIMS AND HEADING,}

These are superceding all others heretofore sold.

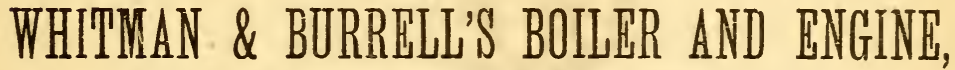

\section{ÁRE STANDARD, BEST AND CHEAPEST.}

HIGHEST AWARDS, LARGE SILVER MEDIL, at American Institute Fair, 1873 and 18\%4, also at Seven' State Fairs and Exposilions.

Simpler, will last lunger, afer, and more economical, than any others. Explosions impossible.

Satisfactory Trial given to any responsible parties.

\section{FRENCH BURR STONE GRIST MILLS,}

Warranted best in in use, for Flour or Coarse Feed.

CHEESE and BUT'TER FACTORY APPARATUS and FIXTUTES, IRON PIPE, HOSE, BELTING, dec., de.

As we manufacture and import our goods from Europe. WE WILL NOT BE UNDERSOLD. Our Goods are the BEST IN THE MARKET. Terms Liberal.

SPECIAI. - On SCALES. CURD KNIVFS, BOILERS and ENGINES AND IRON PIPE we can di much better by our customers thin any other parties in the tride. ALsO ON CHWESE BOXES.

Serd for new and handsomely illustrated Circular giving directions for making finest Herkimer Co. Clieese ind Creamery Butter-for Condensing Milk, preparing Rennets, Aunattoine, and important and interesting to farmers.

WHITMAN \& BÜRELL, Little Falls, N. Y. 


\section{WARRIOR MOWER.}

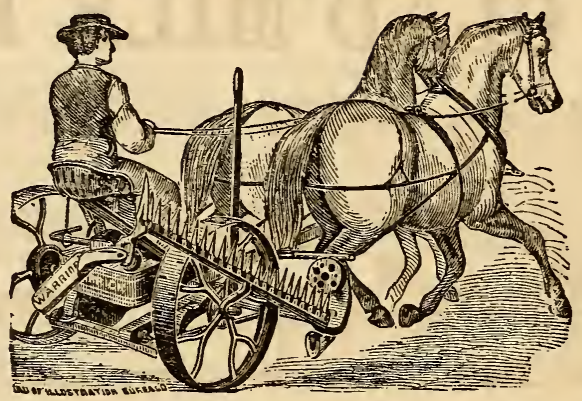

The Mower tested by 12 years, practical use, has proved itself to be thoroughly rellable. and has never falled to give entire satisfaction.

The Warrior Mower Co. formed in 1868, for the special purpose of mannfacturing this machine, located its works in one of the best grazing districts in the country, Iittle Falls. Herkinier Co., New York. They determined at the outset to spare no care ur expense necessary to produce a thoroughly practical and reliable machine. Abundant and voluntary testimony from all parts of the country, warrant the assertion that they have siacceded tu the letter in carrying out their intentions, and that they do furnish a Mower unequaled for durability, lightness of draft, ease of operation, and quality of work.

IV A RRIOR MOWER COMPANY:- $\quad$ LITTLE FALLS, N. Y.

GENTS-Having on several orcasions seen your Warrior Mower at work, and having heard it highly spoken of by practical 1:armers who have used it, 1 judge it to be an excellent machine, which must favorably recummend itself to those desiring a first-class mower.
D.r. Send for Circular to the
X. A. WILLARD.

IV ARRIOR MOWER Co., Litule Falls, N. Y.

\section{RANDALI PULVERISING HARROW.}

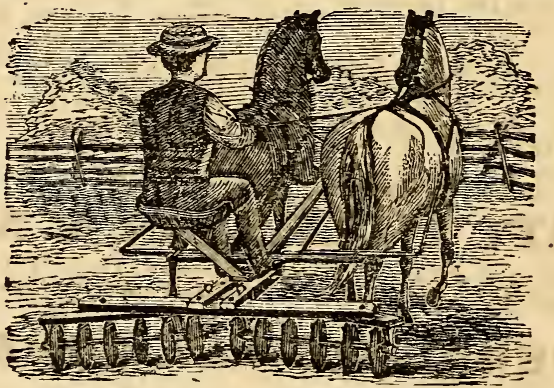

FROM THE SECRETARY AND 'TREASURER OF THE VERMONT DAIRYMEN'S ASSOCIATION

Georgia, Vermont, December 15, $18 \% 4$.

THIS WARRIOR MOWER COMPANY :-Gents: The Rundall Hinrrow, bought if your Mr. liramer last spring. we find all it was recimmended by hlm to be. We esteen it the most valuuble implement for working the soil of which we have iny knowledge. An intelligent neighthor, to wlum re lent it, says that he accomplished more in i wo d: y: with it, in subduing a piece of $t$ witch grass, than he ever accomplished hefore in a week with the best implement at his command. Others of our neighbors endorse his commendation fully.

$$
\text { Very truly yours. }
$$

o. S. BIISS.

With the least expenditure of time. THE RANDALL HARROW secures bv the most perfect thilage, the earliest and most profitable results, in greatly inerensed yield of crups. It cuts, sifts, mashes, grinds, twists, rolls, and breaks all the soil over which it passes, thoroughly pulverising it.

Send for Circular to the 


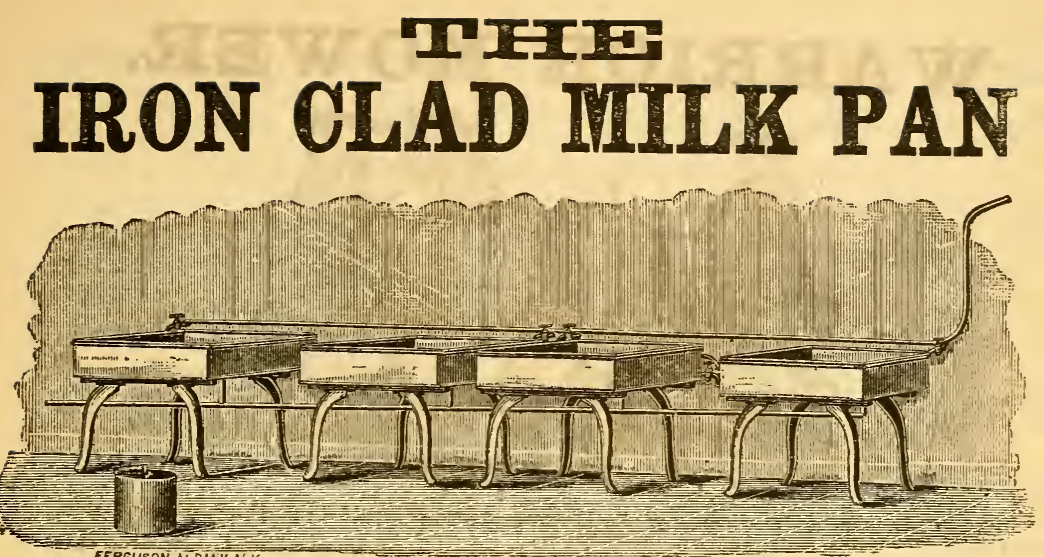

FERGUSON, ALEANY,N. Y.

\section{Has taken First Premium over all other Pans whenever shown in competition with them. Received First Premium at the Great Central N. Y. Fair, held at Utica, October 6th to 14 th, 1874 .}

The following from the Report of Committee on Milk Pans, at State Dairrmen's Convention, beld at Binghamton, December 9th and 10th, 1874:

"The Special Committee on Milk Paus. bave to report that there was on exhihition by BuNNELL \& BRow , of Guilford, Chenango Co., N. Y., the Iron Clad Mi i Pans, by the Orange County Milk Pan Co., of Franklin, Delaware Co.. N. Y., a Pai. manufactured by them, also the Jewett Milk Pan sold by the agency at Delbi, $N$. Y. The committee are only able to report from appearancer, and from these it would seem that the Iron Clad Milk Pan is superic $r$ in many particulars to the others on exbihition."

The duy is not far distant when

\section{EVIEIR I D AIR IIMAIV}

who keeps five cows or nמwards, will use some kind o $f$ Large Milk Pans. The IRON CLAD PAN is conceded hy every dairyman $w$ bo bas c samilied the diflerent kinds i i pans, to be

\section{SUPERIOR TO ALL OTHERS.}

Ther are the only pan in the market that can he used in conl weather to advantage. as they have a steam heating anparatus attaches 1 to them when so desired, by meal is of which the mik can he raised to anv degree of temperature l.y injecting steam in 1 ? water in the vats. Br using the Iron Ciad Pans more butter, and of a better quali'y can be made, with one-fourth tha labor tnan whea small pais are used. Send fir descriptive circulars and price-list, to

\section{BUNNELI \& BROWN, Patentees and Manufacturers, Guilford, Chenango Co., N. $Y$.}


WAS AWARDED THE GOLD MEDAL AT THE

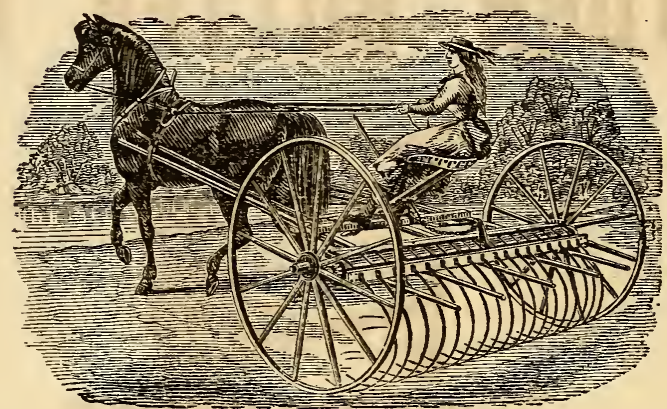

\section{GREAT NATIONAL FIELD TRIAL,}

Near Philadelphia, Pa., 1874.

\section{Axs0, \\ AMERICAN INSTITUTE MEDAL, \\ Same Year.}

The Horse Rake and Mower are important Implements on the Dairy Farm. Wher the Revolving Rake was first introduced, it seemed that perfection had been reached in the way of gathering hay; but soon the Sulky Steel Tooth Rake put in an appearance, crowding out the former, and now the "W WSN ER", steps in and is bound to supersede all others. The Inventor, J. E. WISNER of Friendship, N. Y. (owner of one of the finest Dairy Farms in Wester $\mathrm{N}$. Y.), is a practical farmer, and has invented a Rake that is self-operating-a slight pressure of the foot engaging both wheels for discharging the hay, and yet either wheel works independent of the other, so that it will opcrate equally well while turning to the right or left, making it the most perfect Rake in the world, snd its success is unparalleled in the history of Harvesting Implements.

\section{J. M. CHILDS \& CO.,}

UTICA, N. Y.,

Are General Agents for the "WISMER" SELF-OPERATING RAKE, BUCKEYE Mo WER, and Dealers in First-class Agricultural Implements and Farming Tools, keeping the largest and best assortment in New York State.

Corraspondence sollcited. 


\section{WESTCOTT'S PATENT WUIITE OAES}

RETURN BUTTER PAIL.

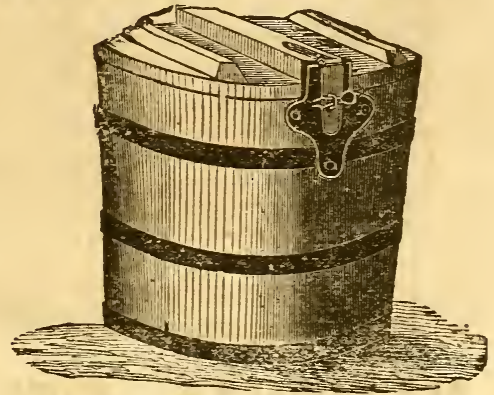

Tis now eight years since this Package was introduced to the public, and experience has proved it to be in all respects the best, and most profitable to use, as the testimony of many of our leading dairymen bears witness.

The object of those who dovote their attention to the production of Batter $\mathbf{i}$, of course, to make money as in any other business, and any aid in increasing the profits of Butter making should be welcome to those directly interested.

By reference to Produce Market Reports it will be ascertained that

\section{PAIL BUTTER BRINGSS FROM 3 TO 7 CENTS MORE}

per pound than any other in New York City market, or an average of 5 cents per pound.

Now, as each pail holds $50 \mathrm{lbs}$., this makes a profit of $\$ 2.50$ on a pail once filled; $\$ 30$ on a dozen, or $\$ 250$ on a hundred,

\section{BESIDES SAVING THE PACKAGE FOR FUTURE USE,}

and time, otherwise necessary to procure new ones.

The charge for returning pails being nominal (about 10 cents each) the profit of using becomes $\varepsilon$, demonstrated fact.

In addition to the Westcott Pail, of $\pi$ hich we are exclusive manufacturers, we also make White Oak Butter Firkins, Haif Firkin Tubs, 25 pcund Butter Pails, and Oak Water Pails, to which wo respectfully invite 1 he attention of the trade, confident that our long experience, extensive facilities and favorahle location, justifies us in promising complete satisfaction to all who may favor us with their commands. Address

\section{SILSBY BRO'S, Belmont, Allegany Co., N. Y.}




\section{THE METALIIC}

\section{BUTTER

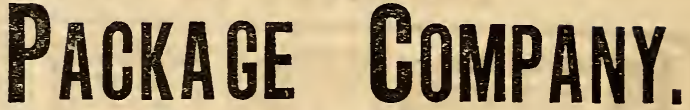

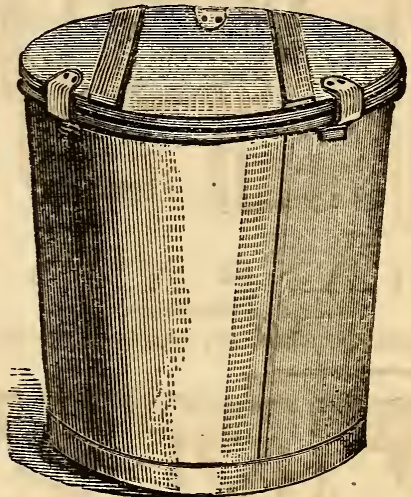

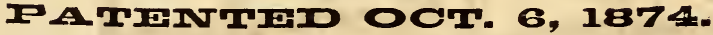

We offer this package to the produrer as a substitute and IMPROVEMrenr, on Il styles of Butter Packages now in use. Its merits are

\section{HEAPIRSS, STRENGTH, WNIPORMITY III SILE, LIGET WHIGHT,}

nd it abolishes the los 3 by SOAKAGE.

Owing to the demand for the special woods required to make the ordinary ackage, the dairy districts have been drained, thus forcing makers to use inferior ackages, and as a result of this the flavor of the wood is imparted to the butter, hich deteriorates its selling value. The Metallic PACKAGE, does away with this. ur package does not absorb any moisiure from the butter, thus ireventing ancidity. No allowance for Soakage has to be made on our Package, the weight $f$ the package being uniform before and after use. It does away. with the vexed uestion of TARES.

Common wood packages weigh from 12 to $25 \mathrm{lbs}$. ,

The Metalic Package weighs only 5 lbs., which is a saving of 25 per cent. on Freight alone. The Fasienings and Covers are simple, Complete, and Duruble.

The Butter can be readily stripped, with no waste occasion ed by discoloratinn f wood staves! The package is as strong as the ordinary wouden tub or Pril, eeps the flavor of the butter longer, and is

\section{AS CHEAP AS THE COMMON KINDS.}

For full particulars, testimonials, etc. Address

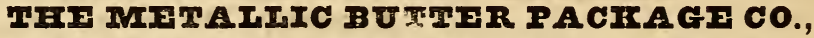
150 Chambers St., ITew Zork. 


\section{CONSTRUCTED UPON CORRECT AND SCIENTIFIC PRINCIPLES IMPROVבD IIN 1873-4.5.}

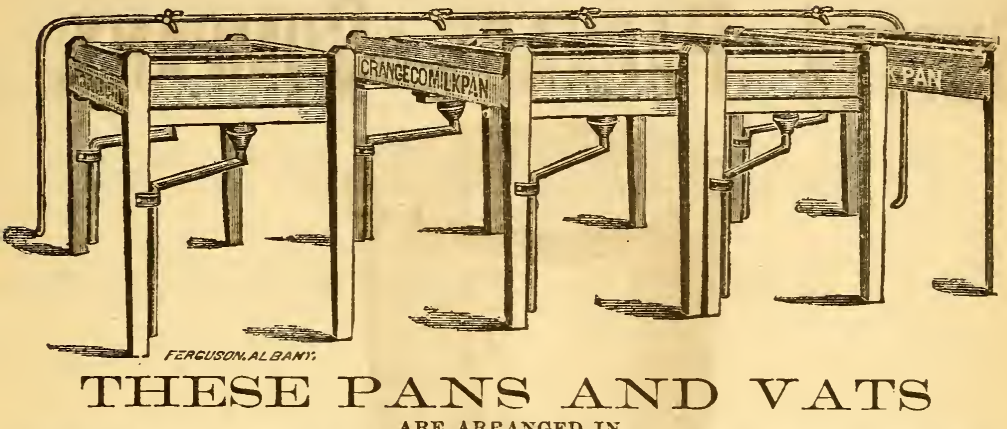

ARE ARPANGED IN

Four Single, or Two Double Racks, whichever best Suits the Size of the Dairy Room.

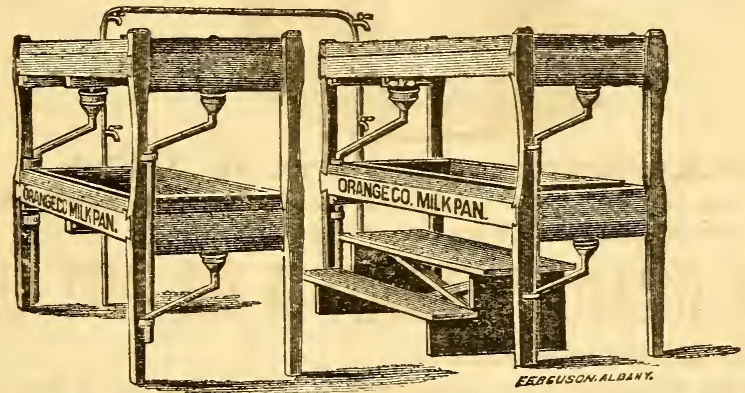

\section{THE ORANGE COUNTY MILK PAN}

(MANUFACTUKED UNDER DOUGLAS'S PATENTS.)

THE SCPERIORITY OF THIS PAN CONSISTS,

1st. In the ense with which the temperature of the milk is controlled, the water coming in contuct with the bottom and sidcs, uniformly and quickly cooling the milk and raising the creuII.

2d. Tlie simple and perfect arrangement for controlling the quantity of water used by mears of the "Patent Water Regulatir"

3d. The convenient manmer of letting off the milk without disturbing tlie water used; an oval form of bottom uakes it easy in washing.

4 th. (an be readily taken from the vat to clean the bottom of pan and insile of water vat, which is.necessary to remuve the slime and gediment deposited by the witer, several tiues in each season.

5th. 'Tliey are most duruble and complete in themselves, needing no benclies ur tubles, it being impossible for u pan or vat to sag wut of shave, or strail the joints.

The sucess that the pan his met with, during the past season, in the States of Vermunt. Massachusetts, Connecticut, New York, Pennsylvania and Ohio, is very tluttering, givilig entire sitisfaction.

T'o turuish the best. most complete and dorable milk pan, to the dirirylug public, is the intention of the Orange County Milk Pan Co. The attention of those interested ill creameries, and all butter makers are invited to its merits.

CORRESPONDENCE REQUISTED AND QUESTIONS CHEERFULLY ANSWERED.

Address ORANGI CUU Eranlilin, Delaware Co., IV. $\mathbf{I}$.

HLLUSTRATL CIRCUIAIR SENT UPON APPLICATHON. 


\section{EI. II. IROE de $00_{-7}$}

MANUFACTURERS OF

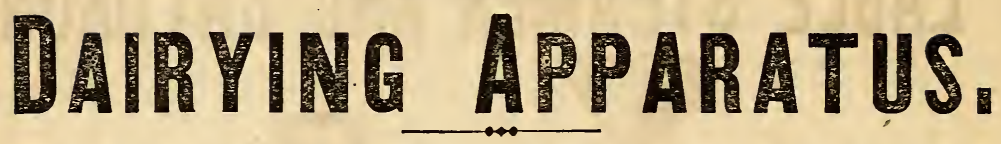

VATS WITH HEATERS ATTACHED A SPECIALTY.

Made in Eleven Sizes.--Guaranteed to Work Satisfactorily.

Vats with Steam Pipes; Curd Drainers; Portable Boilers, adapted for Agricultural Steamers; Portable Engines, can

be used in any place requiring light power; Factory and Dairy Churns; Curd Mills; Hoops and Screws; Improved combination Bea in theese Factory Scales; Curd Knives; Rennet Jars ; Factory Glass and Tin Ware; Account Books, \&c., \&c., \&c.,

\section{KEPT CONSTANTLY IN STOCK. MANUFACTURERS OF}

The Latest and Most Improved

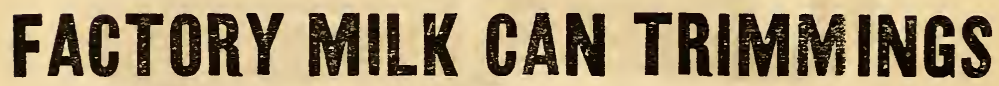

The WHOLEAALE AND IETAIL TRADE promptly supplied at the most favorable rates. TLese Trimmings possess many points of superiority over all others. Parties building Factories will do better by ordering the stock for their cans of us, with other Apparatus, or instructing their tinners to do so. Tin plate bodies furnisbed when desired.

\section{WHOLESALE AND RETAIL DEALERS IN}

\section{Cappings, Rennets, Annatto, ANO FACTORY SUPPLIES GEAERALLY.}

We make the manufacture and sale of this class of goods our exclusive business, and give them our entire attention. Having the benefit of more than sixteen years' experience, we are able to produce the best and most complete goods in every respect. Address for Catalogue, Price Lists, \&c.,

I. II. ROz \& CO.,

Madison, Lake Co., Oh?o. 


\section{EAGLE STEAMER AND GALDRON.}

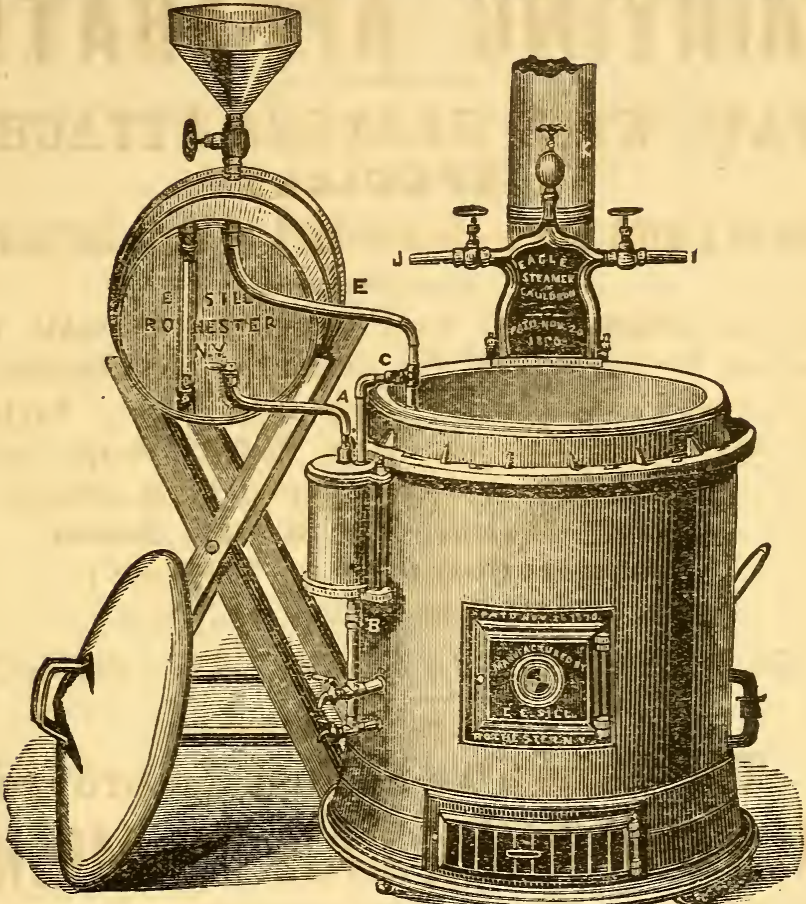

This is a New Steamer recently brought out by E. E. SiLL, of Rochester, N. Y., and is particularly well adapted for Dairy purposes. It is most thoroughly made, and tested up to from 50 to $\% 5 \mathrm{lbs}$. to the square inch under watcr, and from 25 to 35 lbs. under steam before sending out, it has very large flre surface, consequently makes steam easily and rapidly and with small amount of fuel, is perfectly safe, and most easily managed steamer yet offered to the public. The supply barrel is of Iron with water gauge, showing hight of water. Two (2) cut-off cocks to shut off steam and water from steamer while re-flling. This can be done without stopping or loss of steam, the steamer doing full duty while filling barrel. There is also an auiomatic feed or regulator upon steamer, (with gauge glass upon it,) which regulates the hight of water in boiler, always holding it at a given point; the glass showing the exact state of water in boiler. The fire-pot has 1,000 inches of fire and water surface. Being made in this way it is very durable.

The Eagre Steamer is now used in Dairies, Laundries, Bath-Houses, Tannerie?. For steaming lumber and food for stock; in Hospitals and Hotels for cooking, and very many other uses. For Circulars, Prices, Sizes, etc. 


\section{THE \\ AMERICAN}
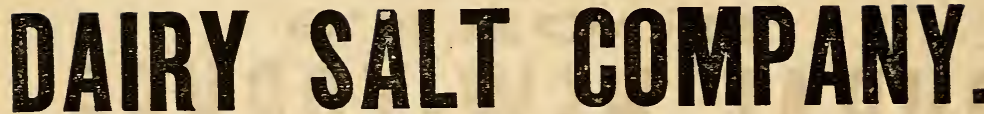

J. W. BARKER,

Pres't and Sec'y.

THOMAS MOLLOY,

Treasurer.

\section{General Office, - - No. 1 Clinton Block,}

\section{SYRACUSE, N. Y.}

\section{SOLE MANUFACTURERS OF THE CELEBRATED ONONDACA FACTORY FILLED}

\section{DAIRY AND TABLE SALT.}

Respectfully call the attention of Dairymen and other's to the quality of Salt now being: manufactured by them.

Having for many years past been engaged in perfecting the various processes for the manufacture of this salt, and by adop:ing the best modes and machinery for the purpose, they feel warranted in saying to the consumer, that the article now produced is superior to any other either of foreign or domestic production. Thw prollowing is an analysis of our salt. and also of Ashton's, and several other well-known branas of English F. F. Salt, made ir April, 1875, by Messis. Waltz and Stillman, Chemists, of New York, under the direction of a committee of the Butter and Cheese Exchange of New York, the various samples being selected by the Committee from lots they found on sale in market.

Onondaga

Onondagg Ashton. Marshall's, Ashton Wash'ton. Higgins. Worth'ton. Deans. Exce's!n, AIIlls

\section{1}

Water...................

Insoluble Miatter... ........ 0.05ti4

Sulphate of Lime......... 1.2272

Sulphate of Matgnesi....... 0.0769

Chloride of Calcium ....... $\ldots 30$.

Chloricte of M.1gnesium... 0.0591

Sulphate of Sodin...........97.79.18

Chloride of Sodium........97.75! 19

$\overline{99.96 \% 4}$

$$
\text { 3 }
$$

$0.0500 \quad 0.0264$

$0.8888 \quad 0.7217$

$0.0 \div 81$

.......

……

(i).1135

$98.40 \% 5$

99.9809
……

0.0473

0.0346

$98.5 \% 4$

$\overline{99.9322}$

\begin{tabular}{c}
\hline 4 \\
\hline 0.5620 \\
0.0616 \\
1.3748 \\
0.0817 \\
0.0124 \\
98.0229 \\
\hline 100.1204
\end{tabular}

\begin{tabular}{c}
\hline$\frac{5}{08960}$ \\
0.0846 \\
1.20433 \\
0.1616 \\
$\dddot{1.051 i}$ \\
97.6809 \\
$\overline{99.0365}$
\end{tabular}

$\frac{6}{0.5120}$
0.0228
1.2309
0.0131
$\cdots \cdots \cdots$
$0.10 \% 6$

0.1076 97.9.35!

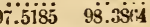

Circulars in regard to various other tests made with this salt in comparison with the best foreign article, also certificates from a large number of the best dairies in the State as to i's quality, may be had on application to J. W. Barker, Secretary, Syraruse, N. Y., to whom orders for salt may also he addresced. It is also for sale by the Agents of the Company in principil Weatern Lake Ports: by St. John \& Avers, 101 and 103 Brnad Street, New Yrrk: Rnhert Geer, 109 Pier, Albany. N. Y.; E. W. Peck \& Co.. Burlington, Vermont, and by dealers generally throughout, the State of $N \in W$ Yirk.

Inquire for ONondaga Factory Filled SAlt.

THOMAS MOLLOY, Treasurer.

$$
\text { J. Th BARIS:R. }
$$

Syracuse, May, 1875. 


\section{"EXCELSIOR!"-"PROGRESS AND IMPROVEMENT."}

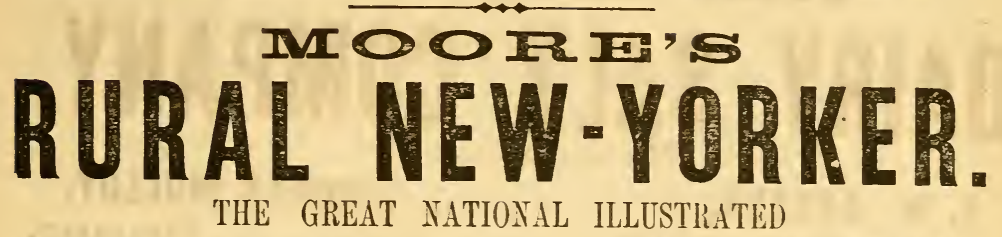

RURAL, LITERARY AND FAMILY WEEKIY.

D. D. T. MOORE, Founder and Conducting Editor,

WITH A CORPS OF ABLE ASSOCLATES AND CONTRIBUTORS.

DURING the past Quarter of a Century this Popular Weekly has attained a circulation, influence and position, which place it in the van of all American contemporaries

in its peculiar and important sphere of journalism. Adhering to its glorious Motto, "Excelsior," and laudable Objects, "Progress and Impiovement," it has long been acknowledged as the leading and

\section{BEST

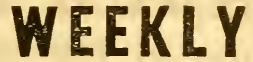 \\ OF

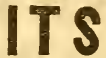 \\ CLASS!}

Moore's RuRal has long been the Standard Authority on all subjects pertaining to Agriculture, Horticulture. and Domestic Affairs. Its Dairy Department, Edited by

X. A. Willard, M. A., is alone worth many times the price of the paper to any one engaged in Dairy Husbandry, The Best Talent is employed upon the Reral New-Yorker, and its Practical Departments are not only able but espeeially adapted to the wants of

\section{THE IARMRR,}

\section{IIII DAIRITMAN,}

IEI STOCIX CROWJR, TEF FORLICUITURIST, MFI FOUS马VIr⿷, \&c.

But in addition to its attention to Practical Affairs, the RURAL is not unmindful of the Family Circle, for it devotes several pages of eaeh number to Choice and High

Toned Literary and Miscellaneonts Reading, adipted to both sexes and all ages. This feature has given it a high reputation, all over the land,

\section{A.S A IITERARY AND FAIMILY PAPER.}

The moral tone of Moore's RUrat has always been pure and unexceptionable, while its value as an Educator is worth many tímes its cost to any family.

\section{THE RURAL'S ILLUSTRATIONS}

Will continue to be Appropriate, Varied and Beautiful. Ir.deed, onr object is to rencler the paper exceptionally Valuable and Acceptable in all its Departments. Its Reports of Markets, Crops, Etc., are alone worth double the price of the RcraL.

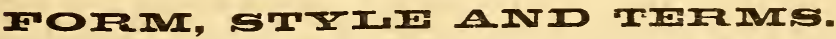

Each Number of the RURAL NEw-Yorker contains Sixteen Quarto Pages, handsomely Printed and Illustrated. A Title Page and Index given at the close of each Volume, ending with June and December.

TERTS, In Advanee, Postage Prepaid:-Only \$2.65 per Year-less to Clubs, and great Inducements to Club Agents. Premium Lists. Specimens, Etc., sent free.

Address

MOORE'S RURAL NEW-YORKER, No. 78 Duane St., New York. 


\section{WIIIIARD'S \\ PRACTICAL DAIRY HUSBANDRY.}

By X. A. WILLARD, M. A.,

Author of Willard's Practical Butter Book, Editor Dairy Husbandry Department of Moore's Rural New-Yorker, Lecturer before various Associations, President New York State Dairymen's Association, Etc., Etc.

\section{FULLY AND HANDSOMELY ILLUSTRATED.}

\section{LARGE OC'TAVO PAGES.-Price $\$ 3$.}

This work comprises a complete treatise on Milk and its products, including

\section{DAIRY FARIIS AND FARIMING;}

GRASSIS ATD CATTIM FOODS;

\section{D.IIRY STOCK, BREEDING, SELECTION AND MANAGEHENT;}

MILK, COMPOSITION, CHATACTER, \&e. HIS'TORY OF

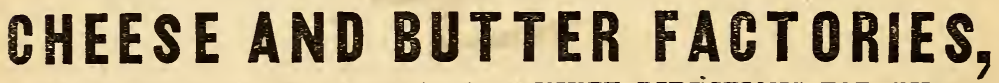

AND MODE OF ORGANIZATION; MINUTE DIRECTIONS FOR THE MANUFACTURE AND CARE OF BUTTER AND CHEESE, BOTH AT FARM DAIRIES AND FACTORIES.

$$
\text { - }
$$

This is the standard work on Dairy Husbandry, and has been highly commended by all the leading Agricultura! and other journals in this country and Europe. The following are a few of the notices in brief:

PRACTICAL DAIRY HUSBANDRY by Hon. X. A. WILlARD, the acknowledged authority on all subjects pertitining to the Dairy, is tlie only standard work of any account in this couniry, and must be regarded as a very valuable addition to agricultural literature.-Vermont Record and Farmer.

It is a book which fils a long unsupplied want, there being nothing of the kind in print which unites general information on dairy farming. with an account of the coustruction of cheese 8 ud butter factories, etc., etc.-Country Gentleman.

This volume will be hailed every where with pleasure. "PRACTICAL DAIRY HUSBANDRY" should be in the hands of every dairyman and former of Vermont.-Rutland (Vt.) Herald.

To a practical dairyman, whetler engaged in the manufacture of butter and cheese or simply in the production of milk, this work is invaluable.-National Live Stock Journal.

The volume is remarkable for its completeness and the clearness and accuracy of its details. No important point connected with the subject appears to have been overlooked, and the style is a model of simplicity and compactness of statement. There are few volumes of the farmers' library that contain such a variety of practical information, and in which the method is so well adapted to the nature of the subject.-New York Tribune.

Mr. X. A. WILLARD is equally well known on this side of the Atlantic as he is in America by all those who study the literature of the dairy. and is certainly the chief exponent in our tine of all that is sound in theory or practice in the production of milk and its conversion into other popular foods. It is the most popular work on Dairy Husbandry that has ever been published. It is the most complete and exhaustive.-London (Engiand) Milk Journal. 


\section{COWI-ES'}

\section{PATENT MILK PAN.}

Patented in United States, Feb. 23, 1873. Patented in Canada, - - March, 187.

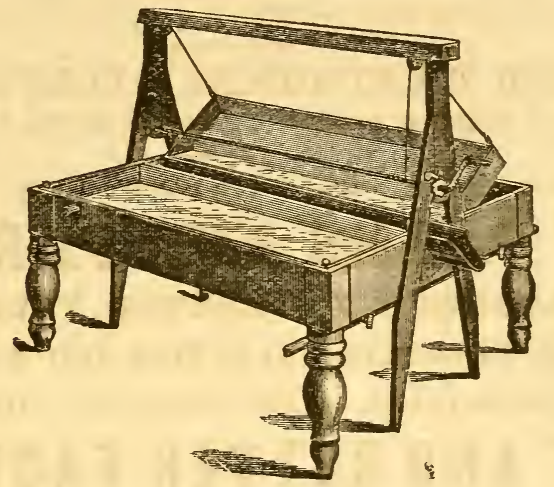

This Pan was Awarded the Medal at the $N$. E. Fair, at Boston, 1873. A Diploma at the N. H. State Fair. The First Prize at Potsdam, N. Y., and other places.

This Pan is the cheapest and most durable large Pan yet invented, and is the only one that empties over the top, thereby aroiding the use of corks, which have proved so troublesome in getting sour, and in allowing the milk to leak. It is simple and easily handled, a child can empty it. The Pan is made of heavy tin, the bottom Japanned or painted to avoid rust, and the vat lined with galvanized iron. It does not wear by using, as it rests on the rim, and the body of the pan touches nothing but water. It is separate from the vat, and can be readily removed if desired for drying or repairs. The water is so arranged that a uniform temperature is obtained, thereby producing more and better cream than by any other arrangement.

Reference is made to the following gentlemen who bave used the "Pan," and have testifled to its merits, viz.:

Hon. L. P. Tenny, Albany, Vt.; O. L. \& A. H. KIDder, Holland, Vt.; WM. Sivright and A. P. Niles, Derby, Vt., and S. S. Cra RK, Potsilam, N. Y.

Parties wishing to order Pans, or to purchase" Territorial Rights" to manufacture, will address.

\section{C. \& W. B. COLBY, Derby Line, Vt.,} or, Stanstead, Prov. Quebec. 


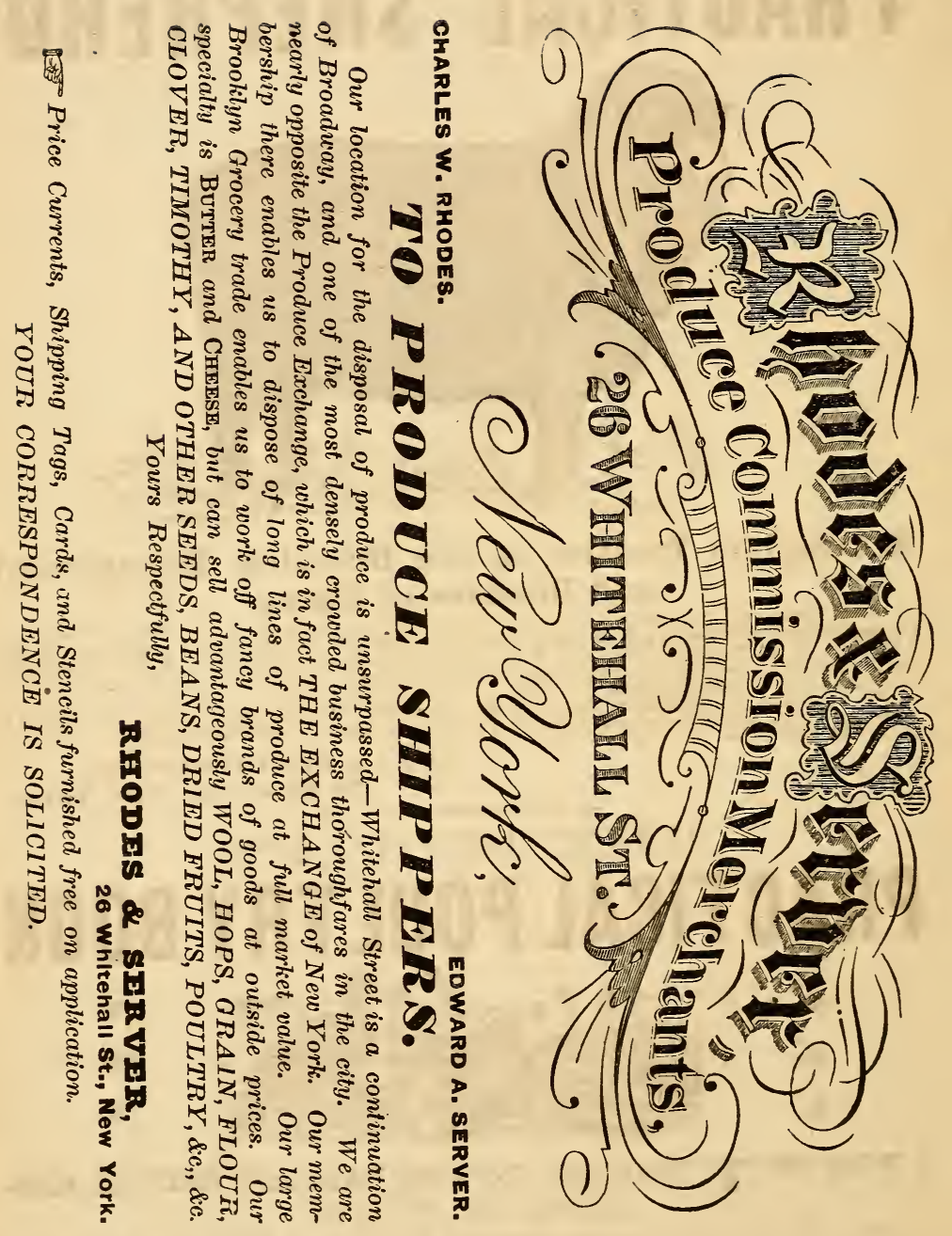




\section{RANDALL'S \\ PRACTICAL SHEPHERD:}

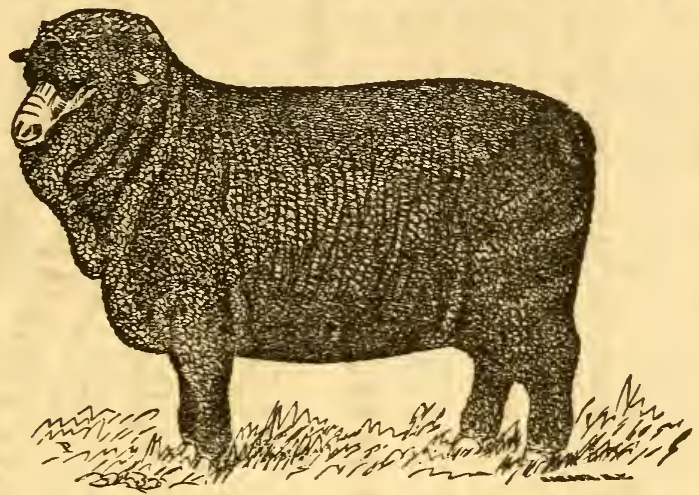

\section{A Complete Treatise on the Breeding, Management}

and Diseases of Sheep.

THIS Work, by the IIon. HENRY S, RANDALL, LL. D., (author of " Sheep Husbandry in the Sonth," "Fine Wowi Slieep Husbandry," \&c.," is the Standurd Authority on the Subject. It is the most complete and reliable T'reatise on American sheep Husbandry ever published, and (as the New England Farmer says) "should be in the hand and head of every person owning sheep."

The PRACTICAL SHEPHERD contains 452 pages, and is illustrated, printed and bound in sunerior style. Twenty-seventh Edition now ready. Sent by mail post-paid, on receipt of price-\$2. Address

RURAL PUBLISHING CO., y 8 Duane St., New York.

\section{THE PEOPLE'S}
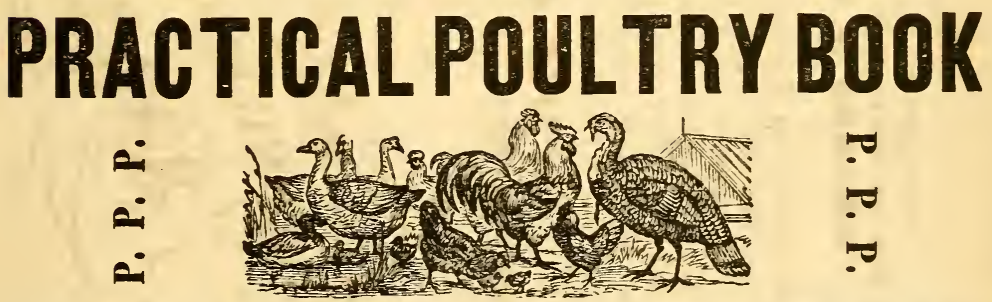

A WORK ON THE BREEDING, REARING, OARE AND GENERAL MANAGEMENT OF POULTRY.

THIS is one of the finest gotten-llp works on the subject on which it treats, for its size and price, of any publication of the kind in this country. It is finely and profusely illustrated, and printed and bound in extra style. Contains 224 large octavo pages. Sent, by mail, post-paid, for $\$ 1.50$. Address

RURA L PULIATHANG CO., 78 Duane St., New York. 


\title{
CHARLES MILIAR \& SON,
}

MAAXTRACTRBRB OF

\section{Improved Apparatus

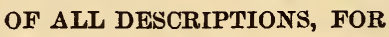

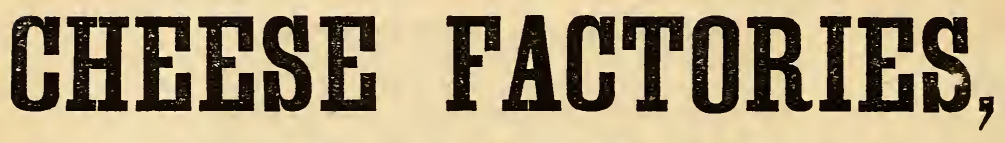

\section{CREAMERIES,}

OR

\section{PRIVATE DAIRIES.}

AISO, DEALERS IN

BANDACE,

\author{
RENNE'TS, \\ AND ALL KINDS OF \\ SCALE TOARDS,
}

FURNISHING GOODS.

SOLE WHOLESALE AGENTS IN AMERICA FOR

\section{NICHOLIS' CELEBRATED}

\section{Extract \\ of \\ Annatto,}

The Best Coloring Matter for Butter or Cheese.

Send for onr full Illustrated Circular.

Address

CHARLES MILLAR \& SON,

Utica, N. $\mathbf{Y}$.

N. B.-Millar's New Portable Engine, "THE IRON SLAVE," is the latest and best Engine for small power purposes made. 



$\infty$

Qn- - 

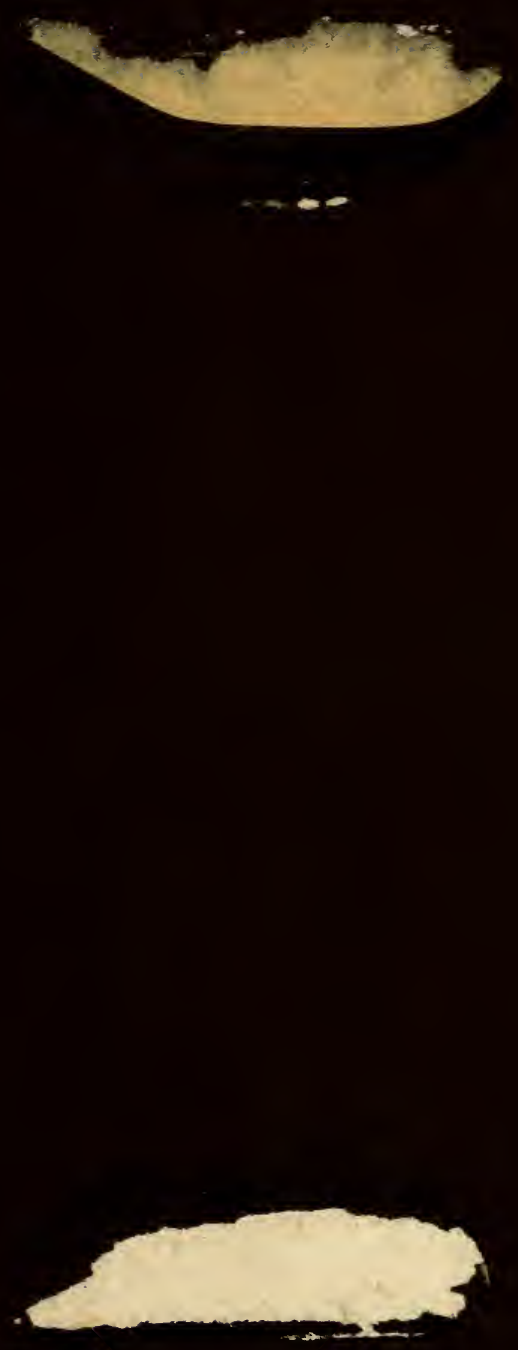
